\title{
ATP as a modulator of inflammation and oxidative stress
}

Citation for published version (APA):

Swennen, E. L. R. (2007). ATP as a modulator of inflammation and oxidative stress. [Doctoral Thesis, Maastricht University]. Universitaire Pers Maastricht. https://doi.org/10.26481/dis.20070412es

Document status and date:

Published: 01/01/2007

DOI:

10.26481/dis.20070412es

Document Version:

Publisher's PDF, also known as Version of record

\section{Please check the document version of this publication:}

- A submitted manuscript is the version of the article upon submission and before peer-review. There can be important differences between the submitted version and the official published version of record.

People interested in the research are advised to contact the author for the final version of the publication, or visit the DOI to the publisher's website.

- The final author version and the galley proof are versions of the publication after peer review.

- The final published version features the final layout of the paper including the volume, issue and page numbers.

Link to publication

\footnotetext{
General rights rights.

- You may freely distribute the URL identifying the publication in the public portal. please follow below link for the End User Agreement:

www.umlib.nl/taverne-license

Take down policy

If you believe that this document breaches copyright please contact us at:

repository@maastrichtuniversity.nl

providing details and we will investigate your claim.
}

Copyright and moral rights for the publications made accessible in the public portal are retained by the authors and/or other copyright owners and it is a condition of accessing publications that users recognise and abide by the legal requirements associated with these

- Users may download and print one copy of any publication from the public portal for the purpose of private study or research.

- You may not further distribute the material or use it for any profit-making activity or commercial gain

If the publication is distributed under the terms of Article $25 \mathrm{fa}$ of the Dutch Copyright Act, indicated by the "Taverne" license above, 


\section{ATP as a modulator of inflammation and oxidative stress}


ISBN: 978-90-5278-606-3

Cover design: Roger Bartholomé Layout: Els Swennen

Production: Datawyse | Universitaire Pers Maastricht
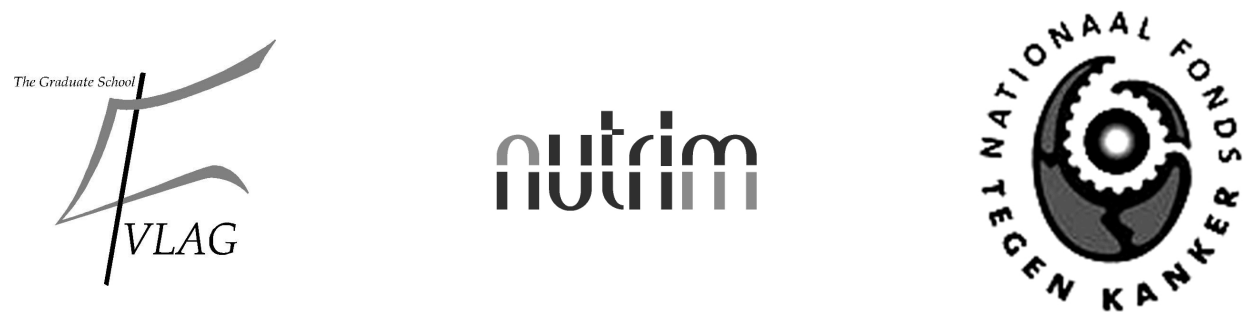

The studies presented in this thesis were funded by the 'St. Nationaal Fonds tegen kanker', W.G. Plein 187, 1054 SC Amsterdam and performed within the Nutrition and Toxicology Research Institute Maastricht (NUTRIM) which participates in the Graduate School VLAG (Food Technology, Agrobiotechnology, Nutrition and Health Sciences), accredited by the Royal Netherlands Academy of Arts and Sciences.

Financially support for printing of this thesis has kindly been provided by the 'St. Nationaal Fonds tegen kanker', Dr. Ir. Van de Laar Stichting, Sanquin, Medische Laboratoria Dr. Stein \& Collegae and Corning B.V. 


\section{ATP as a modulator of inflammation and oxidative stress}

\section{PROEFSCHRIFT}

ter verkrijging van de graad van doctor aan de Universiteit Maastricht, op gezag van de Rector Magnificus, Prof. mr. G.P.M.F. Mols, volgens het besluit van het College van Decanen, in het openbaar te verdedigen op donderdag 12 april 2007 om 14.00 uur

door

Els Louise Rita Swennen

Geboren op 27 april 1979 te Tongeren

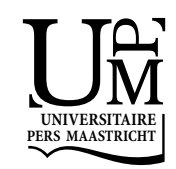




\section{Promotores:}

Prof. dr. A. Bast

Prof. dr. ir. P.A. van den Brandt

\section{Copromotor:}

Dr. ir. P.C. Dagnelie

\section{Beoordelingscommissie:}

Prof. dr. F.J. van Schooten (voorzitter)

Prof. dr. C.A. Bruggeman

Dr. E.H.J. van Haren (Atrium MC, Heerlen)

Prof. dr. F. Di Virgilio (University of Ferrara, Italy)

Prof. dr. B.G. Wouters 
Opgedragen aan mijn oma 



\section{Contents}

Abbreviations

Chapter 1 General introduction

Chapter 2 Immunoregulatory effects of ATP on cytokine release from stimulated whole blood

Chapter 3 ATP inhibits hydroxyl radical formation and the inflammatory response of stimulated whole blood even under circumstances of severe oxidative stress

Chapter 4 Purinergic receptors involved in the immunomodulatory effects of ATP in human blood

Chapter 5 Time-dependent effects of ATP and its degradation products on inflammatory markers in human blood ex vivo

Chapter 6 Radioprotective effects of ATP in human blood ex vivo

Chapter 7 Inflammatory and oxidative stress status in NSCLC patients and the ex vivo immunomodulatory effects of ATP in stimulated blood: a pilot study

Chapter 8 General discussion

Chapter 9 Summary

Samenvatting

Dankwoord

Curriculum vitae

List of publications 



\section{Abbreviations}

AC

ADA

ADP

AMP

AP-1

ATP

ATP $\gamma \mathrm{S}$

CAMP

CD73

CRP

COPD

DMPO

DMSO

DTNB

EDTA

ELISA

ERK

ESR

GPx

GR

$\mathrm{GSH}$

GSSG

GST

$\mathrm{H}_{2} \mathrm{O}_{2}$

$\mathrm{HOCl}$

HPLC

HRP

IFN- $\gamma$

IL

$\mathrm{IP}_{3}$

JNK

LBP

LPS

$\mathrm{NAD}^{+}$

MAPK

MDA

$N F_{\kappa} B$

NK

NO adenylyl cyclase

adenosine deaminase

adenosine 5'-diphosphate

adenosine 5'-monophosphate

activator protein-1

adenosine 5'-triphosphate

adenosine 5'-O-(3-thiotriphosphate)

cyclic AMP

ecto-5'-nucleotidase

C-reactive protein

chronic obstructive pulmonary disease

5,5-dimethyl-1-pyrroline- $\mathrm{N}$-oxide

dimethyl sulfoxide

5,5'-dithiobis-2-nitrobenzoic acid

ethylene diamine-tetraacetic acid

enzyme linked immune sorbent assay

extracellular-signal regulated kinase

electron spin resonance

glutathione peroxidase

glutathione reductase

reduced glutathione

oxdized glutathione

glutathione-S-transferase

hydrogen peroxide

hypochlorous acid

high performance liquid chromatography

horseradish peroxidase

interferon-gamma

interleukin

inositol 1,4,5-triphosphate

c-Jun terminal kinase

lipopolysaccharide-binding protein

lipopolysaccharide

nicotinamide adenine dinucleotide

mitogen-activated protein kinases

malondialdehyde

nuclear factor kappaB

natural killer

nitric oxide 


\begin{tabular}{|c|c|}
\hline NPP & ectonucleotide pyrophosphatase/phosphodiesterase \\
\hline NSCLC & non-small-cell lung cancer \\
\hline NTPDase & ectonucleoside triphosphate diphosphohydrolase \\
\hline $\mathrm{O}_{2}^{\cdot-}$ & superoxide radical \\
\hline $\mathrm{OH}^{\bullet}$ & hydroxyl radical \\
\hline $\mathrm{ONOO}^{-}$ & peroxynitrite \\
\hline PARP & poly (ADP-ribose) polymerase-1 \\
\hline PCA & perchloric acid \\
\hline PHA & phytohemagglutinin \\
\hline PKA & protein kinase $A$ \\
\hline PLC & phospholipase C \\
\hline PNP & purine nucleoside phosphorylase \\
\hline RA & rheumatoid arthritis \\
\hline RNS & reactive nitrogen species \\
\hline ROS & reactive oxygen species \\
\hline SEM & standard error of the mean \\
\hline SOD & superoxide dismutase \\
\hline SSA & sulfosalicyclic acid \\
\hline TCA & trichloric acid \\
\hline TEAC & trolox equivalent antioxidant capacity \\
\hline Th & T-helper \\
\hline TLR & Toll-like receptor \\
\hline TNF- $\alpha$ & tumour necrosis factor-alpha \\
\hline UDP & uridine 5'-diphosphate \\
\hline UTP & uridine 5'-thriphosphate \\
\hline $\mathrm{XO}$ & xanthine oxidase \\
\hline
\end{tabular}




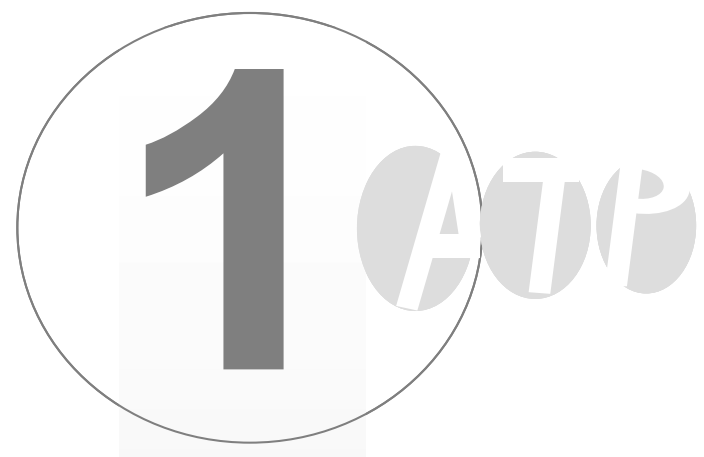

General introduction 
Chapter 1 


\section{ROS and oxidative stress}

Reactive oxygen species (ROS) and reactive nitrogen species (RNS) comprise free radicals and non-radicals. Examples of radical ROS/RNS are superoxide radical $\left(\mathrm{O}_{2}{ }^{\circ-}\right)$, hydroxyl radical $\left(\mathrm{OH}^{\circ}\right)$ and nitric oxide $\left(\mathrm{NO}^{\circ}\right)$ and non-radical ROS/RNS include hydrogen peroxide $\left(\mathrm{H}_{2} \mathrm{O}_{2}\right)$, hypochlorous acid $(\mathrm{HOCl})$ and peroxynitrite (ONOO-) [1]. ROS or RNS can be generated during metabolism of oxygen or nitrogen respectively, by neutrophils and macrophages during inflammation or by irradiation. During metabolism of oxygen for example, $1-3 \%$ of the consumed oxygen is not completely reduced to water, but forms $\mathrm{H}_{2} \mathrm{O}_{2}$ or free radicals [2]. The interaction of ionizing radiation with water, a major cellular constituent, results in the generation of various ROS including $\mathrm{OH}^{\bullet}[3]$.

ROS/RNS are known to play a dual role in biological systems [4]. On the one hand, beneficial effects of ROS involve physiological functions such as metabolism of xenobiotics, smooth muscle relaxation and the respiratory burst to kill invading micro-organisms [4-6]. On the other hand, at high concentrations, ROS can be harmful by damaging practically all compounds occurring in living organisms, including DNA, proteins, carbohydrates and lipids [7].

To protect against these harmful effects of ROS, the human body contains nonenzymatic and enzymatic antioxidant defenses [8, 9]. The enzymatic antioxidant system is composed of enzymes such as superoxide dismutase (SOD), glutathioneperoxidase (GPx) and catalase. In non-enzymatic mechanisms, some antioxidant substances including vitamin $\mathrm{E}$ and glutathione (GSH) protect the cells. When a disturbance of the balance between the production of and the protection against ROS occurs in favour of the production, a situation called oxidative stress occurs.

\section{Inflammation}

\section{Innate and adaptive immune response}

The human immune system comprises an interactive network of immune cells and humoral factors and is essential for protection of the host against microbial infections. The immune system may be divided into two interrelated cascades: the innate and the adaptive immune system [10, 11]. The innate immune system mediates the initial in-born protection against infections while the adaptive immune system develops more slowly during human life and mediates the later defense against infections. The innate immune system is a type of host defense always present in healthy individuals, prepared to block the entry of microbes and involves phagocytic cells such as neutrophils, monocytes and macrophages. 
The adaptive immune system is stimulated by microbes that invade tissues, and is made up by lymphocytes which express T-cell receptors and B-cell receptors, which specifically recognize antigens produced by microbes.

Unlike the adaptive immune system, the innate immune system does not recognize every possible antigen. Instead, it is designed to recognize a few highly conserved structures present in many different micro-organisms, which are called pathogenassociated molecular patterns, for example lipopolysaccharide (LPS).

LPS is an essential outer membrane glycolipid of gram-negative bacteria and is a potent inducer of inflammation. LPS recognition is predominantly mediated by tolllike receptor 4 (TLR4) [12]. This recognition involves the binding of LPS with lipopolysaccharide-binding protein (LBP) and subsequently with CD14, which physically associates with a complex including TLR4 [13, 14]. CD14 is a glycosylphosphatidylinositol-anchored molecule, which is preferentially expressed by monocytes/macrophages and neutrophils. Formation of the TLR4-centered LPS receptor complex activates nuclear factor kappaB $(\mathrm{NF} \kappa \mathrm{B})$. The activation of this transcription factor is due to the phosphorylation and the subsequent degradation or displacement of the inhibitory part of $N F_{\kappa B}$, called $l_{\kappa} B$. This leads to the translocation of $N F \kappa B$ to the nucleus where it associates with specific DNA binding sites and the subsequent production of pro-inflammatory cytokines such as tumour necrosis factor-alpha (TNF- $\alpha$ ), interleukin (IL)-6, IL-1 and IL-12 [15-17] (Figure 1).

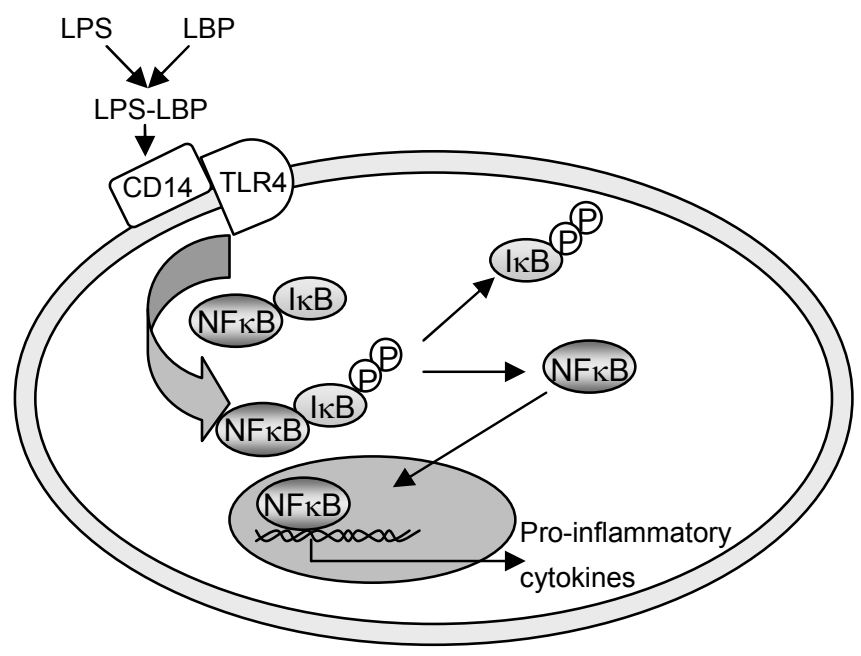

Figure 1: LPS activation of NFKB and the subsequent production of pro-inflammatory cytokines. 
There is a close cooperation between the innate and adaptive immune system; for example, antibodies, which are a component of the adaptive immune system, bind to microbes, and these coated microbes then activate phagocytes, a component of innate immunity, which will destroy the microbes [10]. Moreover, there is evidence that TLRs also contribute to activation of adaptive immune responses, as reviewed by Pasare et al. [18].

\section{Pro- and anti-inflammatory cytokines}

Cytokines, which are mediators of immune responses, are secreted by activated immune cells and can be classified into pro- and anti-inflammatory cytokines [19]. Cytokines regulate both the innate (neutrophils and macrophages) and the adaptive immune system ( $T$ and $B$ lymphocytes). Pro-inflammatory cytokines are mainly produced by activated immune cells and stimulate other immune cells, thereby enhancing inflammatory reactions. In contrast, anti-inflammatory cytokines inhibit activated cells and temper inflammatory responses.

Monocytes and macrophages, activated by the recognition of pathogens, produce a range of pro-inflammatory cytokines such as TNF- $\alpha, \mathrm{IL}-1$ and IL-12. TNF- $\alpha$ can promote inflammatory reactions by stimulating other monocytes, macrophages and neutrophils to migrate to the site of infection, thereby enhancing the production of other inflammatory mediators such as IL- 8 and TNF- $\alpha$ itself, amplifying the TNF- $\alpha$ mediated inflammatory effects [20, 21]. After the initial activation, monocytes and macrophages also produce anti-inflammatory cytokines, such as IL-10, which directly inhibits the production of pro-inflammatory cytokines including TNF- $\alpha$. IL-10 has also been shown to inhibit the production of ROS in isolated macrophages [22, 23].

Activated T-lymphocytes can be divided in T-helper-1 (Th1) and Th2-cells, according to the cytokines they produce. Th1-cells mainly produce interferongamma (IFN- $\gamma$ ) and IL-2; Th2-cells produce IL-4, IL-5 and IL-10. Pro-inflammatory cytokines induce the production of Th1 cytokines, which have by themselves proinflammatory capacities. On the other hand, Th2 cytokines are anti-inflammatory and inhibit Th1 and/or pro-inflammatory cytokines. IL-6, produced by activated monocytes and macrophages and Th2-cells, has both pro- and anti-inflammatory properties [19].

\section{The relation between oxidative stress and inflammation}

ROS are known to mediate inflammation by activating redox-sensitive transcription factors such as $N F \kappa B$ and activator protein (AP)-1, which up-regulate a number of pro-inflammatory genes, resulting in the production of pro-inflammatory cytokines $[20,21]$. It has also been shown that cytokines can trigger a rapid, transient increase in ROS levels [24, 25]. Moreover, the cytokine-induced NF $\kappa B$ activation appears to 
be associated with an intracellular increase in ROS [25]. The involvement of ROS in $\mathrm{NF} \kappa \mathrm{B}$ activation by LPS was recently reviewed by Gloire et al. [25].

The production of ROS and of various cytokines such as TNF- $\alpha$ via NF $\kappa B$ is not only associated, but they even amplify each other. Not only is increased ROS formation a trigger of inflammation, but inflammation itself again triggers ROS production. In this way, a vicious spiral of increased ROS formation and inflammation may occur (Figure 2).

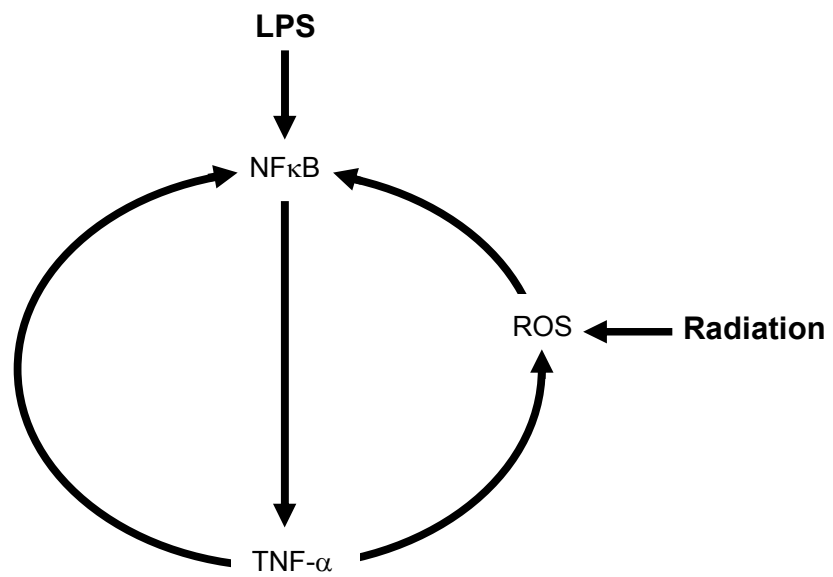

Figure 2: Interplay between inflammation and oxidative stress.

\section{Cancer}

Cancer, a disease characterized by uncontrolled growth and spread of abnormal cells, is together with cardiovascular diseases, one of the major causes of death in humans [26]. In males, lung cancer is the most common cancer, in females it is the third to breast and uterine cancer. Cigarette smoking remains the major risk factor on the incidence of cancer, with $90 \%$ of all lung cancers occurring in smokers.

\section{Cancer and oxidative stress}

Oxidative damage accumulates during life and radical-related damage to DNA, proteins and lipids has been proposed to play a key role in the development of agedependent diseases such as cancer [27]. Valko et al. [28] recently reviewed the involvement of oxidative stress in the carcinogenesis process. Moreover, there is substantial evidence indicating that the redox balance in cancer cells is impaired 
relative to normal human cells [29, 30], which may be related to oncogenic stimulation.

So far, it is not well established whether oxidative stress observed in cancer patients results from an increased production of oxidants in the body or from a failure of physiological antioxidant defense systems. Several mechanisms have been proposed that could lead to oxidative stress in cancer patients. The first one is the altered energy metabolism, which may be attributable to symptoms such as cachexia, nausea and vomiting. These symptoms prevent a normal nutrition and thereby a normal supply of nutrients such as antioxidant vitamins, which lead to an unbalance between antioxidants and oxidants [31]. The second suggested mechanism is a nonspecific chronic activation of the immune system with an excessive production of pro-inflammatory cytokines, which in turn may increase ROS production [32]. A third mechanism may be the effect of alkylating or redoxcycling cytostatics used in cancer treatment [33].

\section{Cancer and inflammation}

Besides various diseases such as chronic obstructive pulmonary disease (COPD) [34] and rheumatoid arthritis (RA) [35], inflammation is also associated with cancer [36-39]. Moreover, in cancer, symptoms such as fatigue and cachexia, which determine the quality of life, are associated with the production of pro-inflammatory cytokines [40-44]. Studies have shown that pro-inflammatory cytokines, induced by the tumour, can directly and indirectly lead to the development of tumour-induced weight loss. Cytokine releases can cause suppressed appetite, changes in the body's ability to metabolize and use macronutrients, acceleration of fat and protein breakdown, leading to loss of body weight and lean body mass.

One approach to reduce side effects in cancer patients and thereby improving the quality of life of these patients could be the administration of an anti-inflammatory agent. Moreover, this reduced inflammatory reaction will lead to a decreased oxidative stress due to less ROS production. An example of anti-inflammatory agents, which are used as highly effective therapeutic agents for treating patients with severe chronic inflammatory conditions, are TNF- $\alpha$ blockers, such as infliximab (Remicade $\AA$ ), etanercept (Enbrel $\left.{ }^{\circ}\right)$ and adalimumab (Humira $\left.{ }^{\circledR}\right)[45,46]$. However, the clinic use of these synthetic TNF- $\alpha$ blockers has also been associated with an increased rate of side effects [47, 48]. Adenosine 5'-triphosphate (ATP), which is a physiological compound ubiquitously present in the human body and which is known to have immunomodulatory effects, may offer new therapeutic possibilities for application in chronic disorders. 


\section{ATP}

\section{General}

ATP is a nucleotide consisting of adenine, ribose and three phosphate groups (Figure 3).

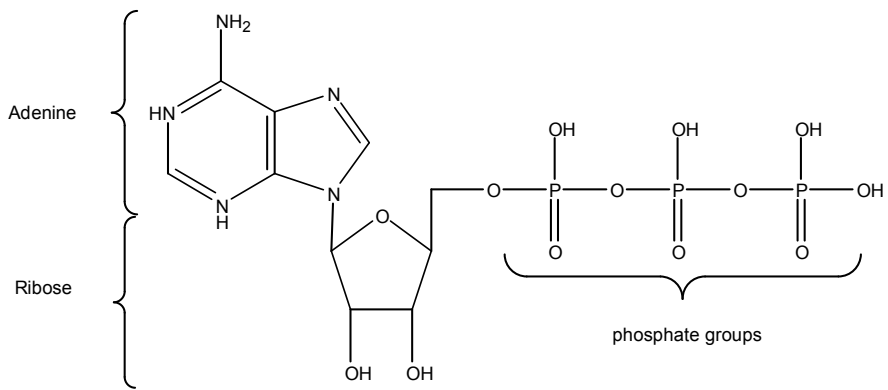

Figure 3: Structure of ATP.

ATP is found in every living cell of the human body and is well-known for its central role in intracellular energy metabolism. In addition, ATP is also widely distributed outside the cell. Even at low concentrations, extracellular ATP appears to influence many biological processes including cardiac function, neurotransmission, muscle contraction and inflammation. Whereas intracellular concentrations of ATP are very high (3-10 mM), its extracellular concentrations are considerably lower. Physiological ATP concentrations in plasma are normally in the sub-micromolar range (400-700 $\mathrm{nM})$. However, extracellular concentrations of ATP can rise markedly under several conditions, including inflammation, hypoxia and ischemia [49-51].

\section{ATP breakdown}

Extracellular ATP is known to be broken down by a cascade of ecto-enzymes located on the plasma membrane or present in a soluble form in the extracellular compartment (Figure 4). The currently known ecto-enzymes, which are involved mainly in the breakdown of ATP, include four families [52, 53]. The first family is the ectonucleoside triphosphate diphosphohydrolase (NTPDase), which catalyzes the sequential degradation of ATP and adenosine 5'-diphosphate (ADP) to adenosine 5'-monophosphate (AMP). The second family consists of ectonucleotide pyrophosphatase/phosphodiesterase (NPP), which catalyzes the hydrolysis of ADP 
to AMP and of AMP to adenosine. The third family comprises the alkaline phosphatases, which catalyze the degradation of ATP to ADP, ADP to AMP and of AMP to adenosine. Finally, the fourth family comprises ecto-5'-nucleotidase (CD73), which catalyzes the hydrolysis of AMP to adenosine. Adenosine can be further degraded to inosine by adenosine deaminase (ADA) or to adenine by a purine nucleoside phosphorylase (PNP). Adenine and inosine can be further broken down to hypoxanthine, which can be degraded to xanthine and finally to uric acid, which is excreted in the urine.

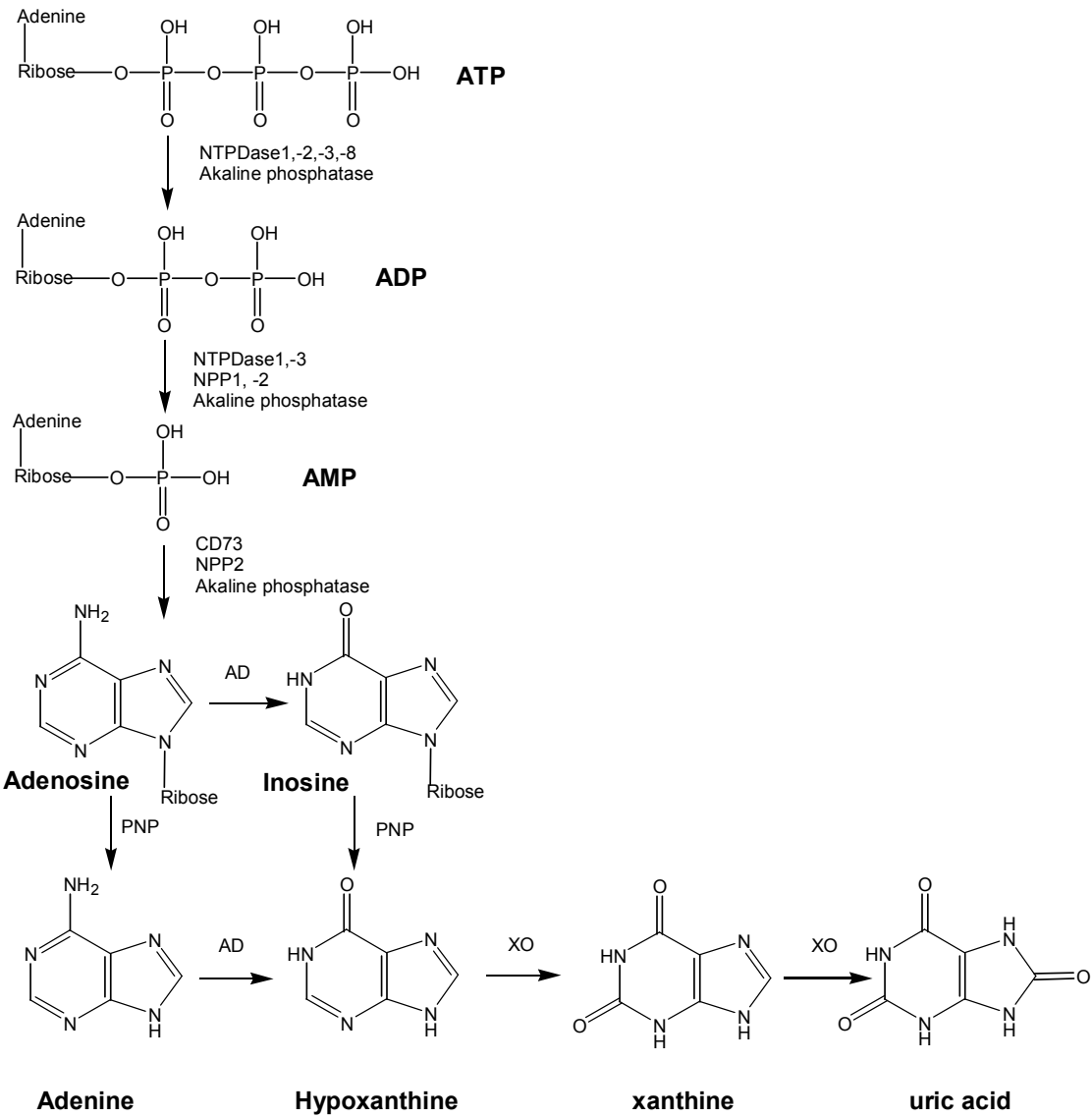

Figure 4: ATP breakdown to uric acid (NTPDase: ectonucleoside triphosphate diphosphohydrolase; NPP: ectonucleotide pyrophosphatase /phosphodiesterase; CD73: ecto-5'-nucleotidase; PNP: purine nucleoside phosphorylase; ADA: adenosine deaminase; XO: xanthine oxidase). 


\section{Purinergic receptors}

Both ATP and its breakdown product adenosine exert extracellular functions via signaling through membrane-bound purinergic receptors. These receptors are widely expressed throughout the body, on a variety of both immune and nonimmune cells. Two families of purinergic receptors have been defined to date, namely $\mathrm{P} 1$ and $\mathrm{P} 2$ receptors (Figure 5). In general, the effects of ATP are mediated via $\mathrm{P} 2$ receptors, whereas adenosine binds to $\mathrm{P} 1$ receptors. The $\mathrm{P} 2$ receptor family is subdivided in two subfamilies, i.e. P2Y and P2X [54]. P2Y receptors are seventransmembrane receptors of which eight subtypes have been identified to date $\left(\mathrm{P}_{2} \mathrm{Y}_{1}, \mathrm{P}_{2} \mathrm{Y}_{2}, \mathrm{P}_{2} \mathrm{Y}_{4}, \mathrm{P}_{2} \mathrm{Y}_{6}, \mathrm{P}_{2} \mathrm{Y}_{11-14}\right.$ ) [55-59], whereas $\mathrm{P} 2 \mathrm{X}$ receptors are ligand-gated ion channels of which seven subtypes have been characterized $\left(P 2 X_{1-7}\right)[60,61]$. $P 1$ receptors belong to the super family of seven-transmembrane receptors and are subdivided into $A_{1}, A_{2 A}, A_{2 B}$ and $A_{3}$ receptor subtypes $[57,62,63]$.

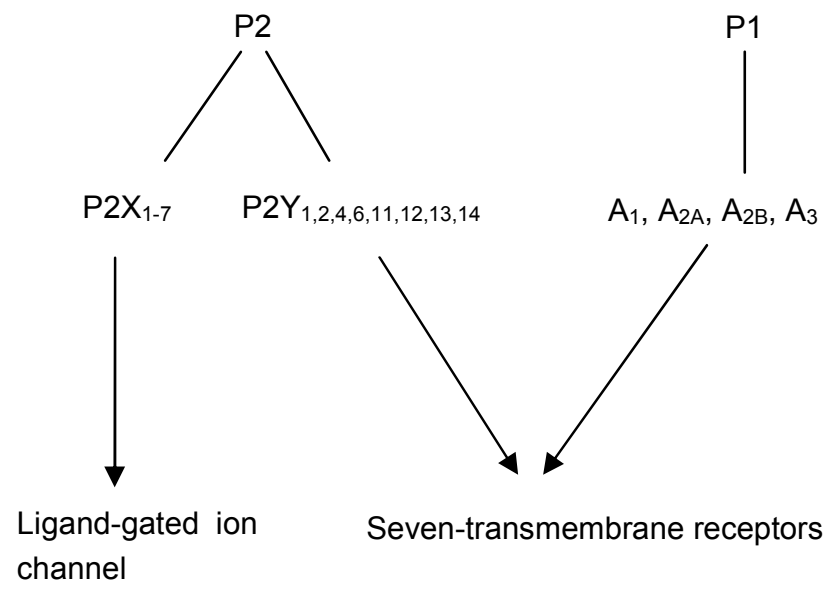

Figure 5: $\mathrm{P} 1$ and $\mathrm{P} 2$ receptor subtypes.

Among the $\mathrm{P} 2 \mathrm{Y}$ receptors, only $\mathrm{P}_{2} \mathrm{Y}_{11}$ is an ATP-specific receptor and is the only cloned P2Y-receptor that is selective for ATP as a naturally occurring agonist [55]. $\mathrm{P}_{2} \mathrm{Y}_{1}, \mathrm{P} 2 \mathrm{Y}_{12}$, and $\mathrm{P} 2 \mathrm{Y}_{13}$ prefer ADP. For the $\mathrm{P} 2 \mathrm{Y}_{2}$ receptor, ATP and uridine 5'triphosphate (UTP) are equipotent $[55,56,64]$. The $\mathrm{P}_{2} \mathrm{Y}_{4}$ receptor is preferentially activated by UTP, $\mathrm{P}_{2} \mathrm{Y}_{6}$ is uridine 5'-diphosphate (UDP) specific and the P2Y 14 receptor subtype is activated by the nucleotide sugar UDP-glucose [65] (Table 1). 
Table 1: P2Y receptor subtypes, G-protein coupling and signal transduction ${ }^{\text {a) }}$.

\begin{tabular}{|c|c|c|c|}
\hline Receptor & Agonist (human) & G protein & Main effector molecules \\
\hline $\mathrm{P}_{2} \mathrm{Y}_{1}$ & ADP & $\mathrm{G}_{\mathrm{q} / 11}$ & $\mathrm{PLC} \uparrow, \mathrm{IP}_{3} \uparrow, \mathrm{Ca}^{2+}$ release \\
\hline $\mathrm{P} 2 \mathrm{Y}_{2}$ & ATP, UTP & $\mathrm{G}_{\mathrm{q} / 11}$ & $\mathrm{PLC} \uparrow, \mathrm{IP}_{3} \uparrow, \mathrm{Ca}^{2+}$ release \\
\hline $\mathrm{P} 2 \mathrm{Y}_{4}$ & UTP & $\mathrm{G}_{\mathrm{q} / 11}$ & $\mathrm{PLC} \uparrow, \mathrm{IP}_{3} \uparrow, \mathrm{Ca}^{2+}$ release \\
\hline $\mathrm{P} \mathrm{Y}_{6}$ & UDP & $\mathrm{G}_{\mathrm{q} / 11}$ & $\mathrm{PLC} \uparrow, \mathrm{IP}_{3} \uparrow, \mathrm{Ca}^{2+}$ release \\
\hline $\mathrm{P}_{2 \mathrm{Y}_{11}}$ & ATP & $\mathrm{G}_{\mathrm{q} / 11}$ and $\mathrm{G}_{\mathrm{s}}$ & $\begin{array}{l}\mathrm{PLC} \uparrow, \mathrm{IP}_{3} \uparrow, \mathrm{Ca}^{2+} \text { release and } \\
\mathrm{AC} \uparrow, \text { increased cAMP }\end{array}$ \\
\hline $\mathrm{P} 2 \mathrm{Y}_{12}$ & ADP & $\mathrm{G}_{\mathrm{i}}$ & AC $\downarrow$, decreased cAMP \\
\hline $\mathrm{P} 2 \mathrm{Y}_{13}$ & ADP & $\mathrm{G}_{\mathrm{i}}$ & AC $\downarrow$, decreased cAMP \\
\hline $\mathrm{P}_{2} \mathrm{Y}_{14}$ & UDP-glucose & $\mathrm{G}_{\mathrm{i}}$ & AC $\downarrow$, decreased cAMP \\
\hline
\end{tabular}

a) PLC= phospholipase $\mathrm{C} ; \mathrm{IP}_{3}=$ inositol 1,4,5-triphosphate; $\mathrm{AC}=$ adenylyl cyclase; $\mathrm{CAMP}=$ cyclic AMP.

After binding of their ligands, most $P 2 Y$ receptors $\left(P 2 Y_{1}, P 2 Y_{2}, P 2 Y_{4}\right.$ and $\left.P 2 Y_{6}\right)$ initiate signaling through $\mathrm{G}_{\mathrm{q}}$ proteins, activating phospholipase $\mathrm{C}$ (PLC), which in turn induces the release of inositol 1,4,5-triphosphate $\left(\mathrm{IP}_{3}\right)$ and thereby results in mobilization of $\mathrm{Ca}^{2+}$ from intracellular stores. Unlike the $\mathrm{G}_{\mathrm{q}}$-coupled $P 2 \mathrm{Y}_{1}$ receptor, the ADP-selective $P 2 Y_{12}$ and $P 2 Y_{13}$ receptors both use $G_{i}$ proteins to inhibit adenylyl cyclase (AC). $P 2 Y_{11}$ has the remarkable and unique property among the P2Y family of being dually coupled to $G_{q}$, thereby activating the PLC pathway, and to $G_{s}$, which leads to AC activation $[55,56,59]$ (Table 1 and Figure 6).

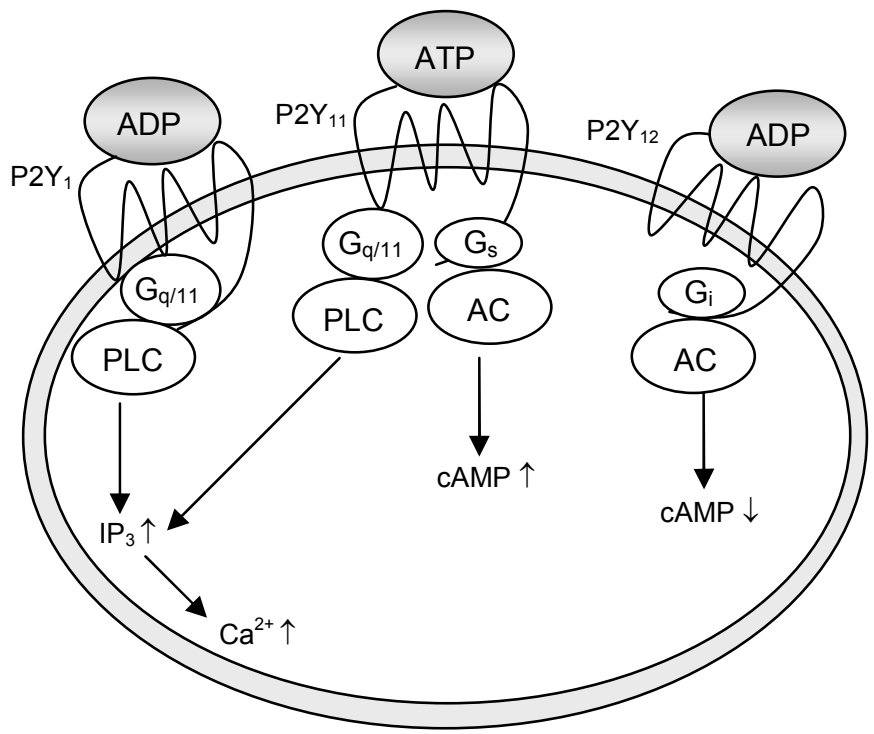

Figure 6: Overview of the intracellular mechanism of the $\mathrm{P} 2 \mathrm{Y}_{1}\left(\mathrm{P} 2 \mathrm{Y}_{2,4,6}\right), \mathrm{P}_{2} \mathrm{Y}_{11}$ and $\mathrm{P} 2 \mathrm{Y}_{12}\left(\mathrm{P} 2 \mathrm{Y}_{13,14}\right)$ receptors. 
For the P2X receptors, signal transduction is relatively simple [54, 61]. The ATPgated ion channels mediate sodium influx, potassium efflux and, to varying extents, calcium efflux, leading to depolarization of the cell membrane. Membrane polarization subsequently activates voltage-gated calcium channels, thereby causing accumulation of calcium ions in the cytoplasm, which is responsible for activating numerous signaling molecules. The intracellular $\mathrm{N}$ and $\mathrm{C}$ termini contain consensus phosphorylation sites for protein kinases such as extracellular-signal regulated kinase $(E R K)$. Activation of these kinases stimulates the transcription factor $\mathrm{NF}_{\kappa} \mathrm{B}$, thereby leading to the synthesis and secretion of cytokines. The $\mathrm{P}_{2} \mathrm{X}_{7}$ receptor is distinct among the $\mathrm{P} 2 \mathrm{X}$ receptors, because it can form both cation channels and, after prolonged activation in some cell types, non-selective pores that allow passage of larger molecules.

It is well known that oxidative stress can affect both receptor function and signal transmission systems. Van der Vliet et al. [66] reported that oxidative stress can affect receptor function by influencing the binding of ligands to membrane receptors and the subsequent signal transduction system, i.e. the coupling of these receptors to G-proteins or affecting the second messenger activity. These effects of oxidative stress could be caused either by peroxidation of membrane lipids, or by interaction of ROS with functional thiol or disulfide groups in the receptor.

\section{ATP and oxidative stress}

There is evidence that intracellular ATP concentrations decrease upon exposure to oxidative stress. $\mathrm{H}_{2} \mathrm{O}_{2}$ rapidly depleted intracellular ATP levels and thereby causes cell death in brain cells [67] and astrocytes [68]. ATP depletion by $\mathrm{H}_{2} \mathrm{O}_{2}$ was explained by inactivation of mitochondrial ATP synthase or by activation of the nuclear enzyme poly(ADP-ribose) polymerase-1 (PARP). Activation of PARP as a consequence of ROS-induced DNA damage, which causes the excessive use of substrates such as nicotinamide adenine dinucleotide $\left(\mathrm{NAD}^{+}\right)$and $\mathrm{ATP}$, induced cell death either by apoptosis or by necrosis $[69,70]$. Oxidative stress can also lead to oxidation of thiol-moieties in membrane bound $\mathrm{Ca}^{2+}$-ATP-ases, causing an inhibition in membrane ATP-ase activity [71]. Therefore, periods of oxidative stress are often followed by an increase in $\mathrm{Ca}^{2+}$-influx and intracellular $\mathrm{Ca}^{2+}$ levels, which can result in cell death. Thus, blockade of the depletion of cellular ATP level would be important in the resistance of cells against oxidative stress and in the protection against oxidative stress-induced cell death.

The role of extracellular ATP during adaptation and protection against oxidative stress is not well understood because there is little knowledge about the effects of ATP in the presence of oxidative stress. For instance, Yoo et al. [68] reported that ATP was able to protect astrocytes from $\mathrm{H}_{2} \mathrm{O}_{2}$-induced cell death by restoration of cellular ATP levels. On the other hand, Shinozaki et al. [72] showed that ATP 
protected astrocytes from $\mathrm{H}_{2} \mathrm{O}_{2}$-induced cell death via $\mathrm{P} 2 \mathrm{Y}_{1}$ receptor-mediated pathways.

The mechanism responsible for this protective effect of ATP involved up-regulation of oxido-reductase genes, but the precise target genes and the $\mathrm{P}_{2} \mathrm{Y}_{1}$ receptor mediated protective action in these cells remained unclear. Moreover, it was shown that ATP was also able to protect, by way of a receptor-mediated mechanism, against hypoxia and oxidative stress induced injury in renal proximal tubes $[73,74]$. It is also known that cell death can cause the release of ATP, followed by activation of purinergic receptors and the mediation of responses essential for survival. Ahmed at al. [75] showed that ATP was released from lung epithelial cells during ozone exposure and that this extracellular ATP protected against ozone toxicity, thus preventing cell death. It was also shown that ATP release from human lung endothelial cells exposed to elevated concentrations of oxygen (hyperoxia) was essential for survival of the cells [76]. Other stress situations, such as shear, hypotonia, and hypoxia have also been shown to cause ATP release $[49,50,77$, 78].

An important function of inflammatory neutrophils, monocytes and macrophages is the destruction and elimination of potentially harmful pathogens by the mobilization of microbicidal molecules (i.e. oxidative burst) either into the phagolysosome or into the extracellular space $[79,80]$. ATP has been shown to contribute to the initiation of the oxidative burst. ATP appears to prime neutrophils for functional responses to various inflammatory mediators, as indicated by increased production of ROS [8183]. Extracellular nucleotides have also been shown to stimulate ROS generation by rat alveolar macrophages [84], guinea pig peritoneal macrophages [85] and human monocyte-derived macrophages [86]. These effects were shown to be $\mathrm{P}_{2} \mathrm{X}_{7^{-}}$ independent. Moreover, extracellular ATP was shown to enhance LPS-induced NO* production in mouse macrophages [87], probably via $\mathrm{P}_{2} \mathrm{X}_{7}$ receptor activation [88, 89].

\section{ATP and inflammation}

Over the past decades, evidence has accumulated indicating that extracellular nucleotides and nucleosides may be important regulators of inflammatory and immune responses in cell lines. Modulation of inflammatory processes and immune responses by extracellular ATP is complex and results from specific effects on a wide variety of both immune and non-immune cells. The immunomodulatory effects of ATP in different immune cell types have been described by Di Virgilio et al. [90, 91] and were recently reviewed by our group [92]. In short, our recently published review summarizes that ATP and adenosine are important endogenous signaling molecules in immunity and inflammation through activation of purinergic receptors. The immunomodulatory effects of ATP on cytokine release by different immune cells are not straightforward and may depend on its extracellular concentration, the 
cellular expression of purinergic receptor subtypes and ecto-enzymes and the celltype studied, which are all parameters which can be affected by various inflammatory mediators.

Several reports indicate that ATP at millimolar levels induces pro-inflammatory effects through activation of $\mathrm{P} 2 \mathrm{X}_{7}$ receptors, whereas the effects of lower ATP levels (low micromolar concentrations), which may occur via P2Y receptor activation, seemed to attenuate pro-inflammatory cytokine production by monocytes, macrophages, dendritic cells and lymphocytes. $\mathrm{P} 1$ receptor signaling by adenosine seemed to be mostly anti-inflammatory. Both ATP as well as adenosine can be seen as danger molecules due to their extracellular rise in response to inflammation and tissue damage $[49,51]$.

\section{Favourable effects of ATP in relation to cancer}

Potential application of ATP in cancer treatment has aroused increasing interest over the past decade [93].

\section{Cytostatic properties of ATP}

The anticancer activity of ATP was first described in 1983 [94]. It was shown that extracellular ATP exerts cytostatic and cytotoxic effects on several tumour cell lines, which were stronger than the effect upon non-transformed mother cells [95-97]. The anti-tumour effects of ATP via P2 receptor activation were recently reviewed by White et al. [98]. This review summarized that extracellular nucleotides can regulate proliferation, differentiation and apoptosis of cancer cells through different P2 receptor subtypes. In the in vivo studies performed by Rapaport et al., mice were inoculated with cancer cells and were given systemic ATP. The results showed that intraperitoneal injections of ATP inhibited tumour growth, weight loss and prolonged survival time [99, 100]. In Ehrlich-ascites-tumour-bearing mice, daily administration of exogenous ATP ( $1 \mathrm{mmol} / \mathrm{kg})$ during 7 days, induced an inhibition of tumour growth [101].

\section{ATP as a chemosensitizer}

Several reports have shown that ATP may selectively enhance cytotoxicity of a number of cytostatic drugs in various cancer cell lines, whereas this effect was not found in normal cells. ATP markedly increased the passive permeability for several chemotherapeutic agents such as fluorouracil and doxorubicin, an effect which was specific for transformed cells [102-104], making cancer cells more sensitive to cytostatics, without causing damage to normal cells. In Ehrlich-ascites-tumourbearing mice, ATP ( $1 \mathrm{mmol} / \mathrm{kg}$ per day) showed a synergistic action when combined with recombinant human TNF- $\alpha$ administration [105]. 


\section{ATP and radiotherapy}

Estrela et al. [106] showed that the combination of radiotherapy and ATP administration led to reduced GSH-levels in tumour cells, but not in normal cells, making cancer cells more sensitive to therapy. This offers an interesting new avenue in cancer therapy. Furthermore, the protecting effects of ATP against radiation damage on normal tissues were shown in various animals by enhancing the survival rates [107, 108]. In addition, Senagore et al. [109] demonstrated that intravenous ATP- $\mathrm{MgCl}_{2}$ infusions in pigs offered significant cytoprotection from pelvic radiotherapy by diminishing colorectal seromuscular ischaemia and decreasing skin and subcutaneous tissue injury and inflammatory reactions.

\section{Human studies with ATP}

A phase I and phase II trial with intravenous administration of ATP in non-small-cell lung cancer (NSCLC) patients was reported by Haskell et al. [110, 111]. It was concluded from these trials that systemic administration of ATP during $96 \mathrm{~h}$ (with a maximum tolerated dose of $75 \mu \mathrm{g} / \mathrm{kg} / \mathrm{min}$ ) is safe.

Agteresch et al. [112-114] performed a randomized clinical trial to evaluate the effects of ATP infusion on body weight, muscle strength and quality of life in patients with advanced NSCLC who had previously been treated with radiotherapy. Patients were randomized to receive either both supportive care and ATP (ATP group, $n=28$, $30 \mathrm{~h}$ ATP infusion), or supportive care alone (control group, $\mathrm{n}=30$ ). Results showed that regular infusions of ATP induced a marked increase of survival (from 3.5 to 9.3 months) in stage IIIB NSCLC patients who had lost $\geq 5 \%$ of body weight prior to inclusion in the study, compared to a control group of patients receiving usual palliative care only. Moreover, physical and functional quality of life, fatigue, appetite, weight and muscle strength remained stable for 6 months in the ATP group, but progressively deteriorated in the control group. ATP also induced stabilization of albumin levels; moreover, data in a subgroup of patients suggested potential inhibition of the acute phase response (C-reactive protein). 


\section{Aim and outline of the thesis}

The hypothesis underlying the present thesis is that the favourable effects of ATP on quality of life and nutrition in advanced lung cancer patients, as shown by Agteresch et al. [112-114], could be due to modulatory effects of ATP on inflammation and oxidative stress.

Therefore, the primary aims of this thesis are:

- To investigate the immunomodulatory effects of ATP on cytokine release in LPSPHA-stimulated blood of healthy subjects ex vivo;

- To explore potential intra- and extracellular mechanisms and identify purinergic receptors subtypes involved;

- To study the effects of ATP on radiation-induced damage in ex vivo irradiated blood of healthy volunteers.

Chapter 2 presents the effects of ATP on the release of a pro-inflammatory (TNF- $\alpha$ ) and an anti-inflammatory cytokine (IL-10) induced by LPS and PHA in human blood of healthy volunteers. These effects of ATP are also investigated in the presence of oxidative stress (as simulated by the co-incubation with different concentrations of $\mathrm{H}_{2} \mathrm{O}_{2}$ ) in chapter 3. Moreover, the direct effect of ATP on oxidative stress by measuring the scavenging effect of ATP on $\mathrm{OH}^{*}$ has been explored.

Chapter 4 describes a study aimed at identifying the purinergic receptors involved in the anti-inflammatory effects of ATP by using several specific receptor agonists and antagonist. In chapter $\mathbf{5}$, the breakdown profile of ATP and the subsequent formation of its metabolites are investigated in the LPS-PHA-stimulated blood model. Moreover, the time-dependent effect of ATP and its metabolites on several inflammatory markers are studied at different time-points after LPS-PHA stimulation. Finally, the involvement of the transcription factor $N F \kappa B$ in the shown antiinflammatory effects of ATP has been investigated.

In chapter 6, the effects of ATP on several inflammatory markers and DNA damage induced after irradiation of blood ex vivo are described. Finally, the ex vivo antiinflammatory effects of ATP are further examined in NSCLC patients and healthy controls in chapter 7 . Moreover, the antioxidant and the inflammatory status of the patients and their matched controls is also quantified.

In chapter 8, a general discussion, together with some further prospects is presented. In conclusion, this thesis supports the value of ATP as a remarkable natural compound, which is able to modulate inflammation, to scavenge $\mathrm{OH}^{\circ}$ and to alleviate radiation-toxicity in normal blood cells. 


\section{References}

1 Kohen R. and Nyska A. Oxidation of biological systems: oxidative stress phenomena, antioxidants, redox reactions, and methods for their quantification. Toxicol Pathol 2002; 30: 620-650.

2 Magder S. Reactive oxygen species: toxic molecules or spark of life? Crit Care 2006; 10: 208.

3 Nair C.K., Parida D.K. and Nomura T. Radioprotectors in radiotherapy. J Radiat Res (Tokyo) 2001; 42: 21-37.

4 Bast A., Haenen G.R. and Doelman C.J. Oxidants and antioxidants: state of the art. Am J Med 1991; 91: 2S-13S.

5 Moncada S., Palmer R.M. and Higgs E.A. Biosynthesis of nitric oxide from L-arginine. A pathway for the regulation of cell function and communication. Biochem Pharmacol 1989; 38: 1709-1715.

6 Bast $\mathrm{A}$. Is formation of an reactive oxygen by cytochrome P450 perilous and predictable? Trends Pharmacol Sci 1986: 266-270.

7 Poli G., Leonarduzzi G., Biasi F. and Chiarpotto E. Oxidative stress and cell signalling. Curr Med Chem 2004; 11: 1163-1182.

8 Sies H. Strategies of antioxidant defense. Eur J Biochem 1993; 215: 213-219.

9 Halliwell B. Antioxidants in human health and disease. Annu Rev Nutr 1996; 16: 33-50.

10 Abbas A.K. and Lichtman A.H., Basic Immunology: Functions and disorders of the immune system. W.B. Saunders Company, Philadelphia: 2004.

11 Parkin J. and Cohen B. An overview of the immune system. Lancet 2001; 357: 1777-1789.

12 Takeda K. and Akira S. Roles of Toll-like receptors in innate immune responses. Genes Cells 2001; 6: 733-742.

13 Akira S. and Takeda K. Toll-like receptor signalling. Nat Rev Immunol 2004; 4: 499-511.

14 Schletter J., Heine H., Ulmer A.J. and Rietschel E.T. Molecular mechanisms of endotoxin activity. Arch Microbiol 1995; 164: 383-389.

15 Jiang Q., Akashi S., Miyake K. and Petty H.R. Lipopolysaccharide induces physical proximity between CD14 and toll-like receptor 4 (TLR4) prior to nuclear translocation of NF-kappa B. $J$ Immunol 2000; 165: 3541-3544.

16 Karin M. and Ben Neriah Y. Phosphorylation meets ubiquitination: the control of NF-[kappa]B activity. Annu Rev Immunol 2000; 18: 621-663.

17 Barnes P.J. and Karin M. Nuclear factor-kappaB: a pivotal transcription factor in chronic inflammatory diseases. N Engl J Med 1997; 336: 1066-1071.

18 Pasare C. and Medzhitov R. Toll-like receptors: linking innate and adaptive immunity. Microbes Infect 2004; 6: 1382-1387.

19 Curfs J.H., Meis J.F. and Hoogkamp-Korstanje J.A. A primer on cytokines: sources, receptors, effects, and inducers. Clin Microbiol Rev 1997; 10: 742-780.

20 Rahman I. and MacNee W. Role of transcription factors in inflammatory lung diseases. Thorax 1998; 53: 601-612.

21 Rahman I. Oxidative stress, transcription factors and chromatin remodelling in lung inflammation. Biochem Pharmacol 2002; 64: 935-942.

22 Dokka S., Shi X., Leonard S., Wang L., Castranova V. and Rojanasakul Y. Interleukin-10mediated inhibition of free radical generation in macrophages. Am J Physiol Lung Cell Mol Physiol 2001; 280: L1196-1202.

23 Selzman C.H., Shames B.D., Miller S.A., Pulido E.J., Meng X., Mclntyre R.C., Jr. and Harken A.H. Therapeutic implications of interleukin-10 in surgical disease. Shock 1998; 10: 309-318.

24 Schoonbroodt S. and Piette J. Oxidative stress interference with the nuclear factor-kappa B activation pathways. Biochem Pharmacol 2000; 60: 1075-1083. 
25 Gloire G., Legrand-Poels S. and Piette J. NF-kappaB activation by reactive oxygen species: Fifteen years later. Biochem Pharmacol 2006.

26 Parkin D.M., Bray F., Ferlay J. and Pisani P. Global cancer statistics, 2002. CA Cancer J Clin 2005; 55: 74-108.

27 Ames B.N., Shigenaga M.K. and Hagen T.M. Oxidants, antioxidants, and the degenerative diseases of aging. Proc Natl Acad Sci U S A 1993; 90: 7915-7922.

28 Valko M., Rhodes C.J., Moncol J., Izakovic M. and Mazur M. Free radicals, metals and antioxidants in oxidative stress-induced cancer. Chem Biol Interact 2006; 160: 1-40.

29 Oberley T.D. and Oberley L.W. Antioxidant enzyme levels in cancer. Histol Histopathol 1997; 12: 525-535.

30 Szatrowski T.P. and Nathan C.F. Production of large amounts of hydrogen peroxide by human tumour cells. Cancer Res 1991; 51: 794-798.

31 Ceriello A. Oxidative stress and glycemic regulation. Metabolism 2000; 49: 27-29.

32 Mantovani G., Maccio A., Lai P., Massa E., Ghiani M. and Santona M.C. Cytokine activity in cancer-related anorexia/cachexia: role of megestrol acetate and medroxyprogesterone acetate. Semin Oncol 1998; 25: 45-52.

33 Weijl N.I., Cleton F.J. and Osanto S. Free radicals and antioxidants in chemotherapy-induced toxicity. Cancer Treat Rev 1997; 23: 209-240.

34 O'Donnell R., Breen D., Wilson S. and Djukanovic R. Inflammatory cells in the airways in COPD. Thorax 2006; 61: 448-454.

35 Smolen J.S., Redlich K., Zwerina J., Aletaha D., Steiner G. and Schett G. Pro-inflammatory cytokines in rheumatoid arthritis: pathogenetic and therapeutic aspects. Clin Rev Allergy Immunol 2005; 28: 239-248.

36 de Visser K.E., Eichten A. and Coussens L.M. Paradoxical roles of the immune system during cancer development. Nat Rev Cancer 2006; 6: 24-37.

37 Marx J. Cancer research. Inflammation and cancer: the link grows stronger. Science 2004; 306: 966-968.

38 Karin M. NF-kappaB and cancer: mechanisms and targets. Mol Carcinog 2006; 45: 355-361.

39 Karin M. Nuclear factor-kappaB in cancer development and progression. Nature 2006; 441: 431-436.

40 Gutstein H.B. The biologic basis of fatigue. Cancer 2001; 92: 1678-1683.

41 von Haehling S., Genth-Zotz S., Anker S.D. and Volk H.D. Cachexia: a therapeutic approach beyond cytokine antagonism. Int J Cardiol 2002; 85: 173-183.

42 Kurzrock R. The role of cytokines in cancer-related fatigue. Cancer 2001; 92: 1684-1688.

43 Moldawer L.L., Rogy M.A. and Lowry S.F. The role of cytokines in cancer cachexia. JPEN J Parenter Enteral Nutr 1992; 16: 43S-49S.

44 Sharma R. and Anker S.D. Cytokines, apoptosis and cachexia: the potential for TNF antagonism. Int J Cardiol 2002; 85: 161-171.

45 Reimold A.M. New indications for treatment of chronic inflammation by TNF-alpha blockade. Am J Med Sci 2003; 325: 75-92.

46 Atzeni F., Sarzi-Puttini P., Doria A., laccarino L. and Capsoni F. Potential off-label use of infliximab in autoimmune and non-autoimmune diseases: a review. Autoimmun Rev 2005; 4: 144-152.

47 Crum N.F., Lederman E.R. and Wallace M.R. Infections associated with tumour necrosis factor-alpha antagonists. Medicine (Baltimore) 2005; 84: 291-302.

48 Bakleh M., Tleyjeh I., Matteson E.L., Osmon D.R. and Berbari E.F. Infectious complications of tumour necrosis factor-alpha antagonists. Int J Dermatol 2005; 44: 443-448.

49 Bodin P. and Burnstock G. Purinergic signalling: ATP release. Neurochem Res 2001; 26: 959969. 
50 Lazarowski E.R., Boucher R.C. and Harden T.K. Mechanisms of release of nucleotides and integration of their action as P2X- and P2Y-receptor activating molecules. Mol Pharmacol 2003; 64: 785-795.

51 Bodin P. and Burnstock G. Increased release of ATP from endothelial cells during acute inflammation. Inflamm Res 1998; 47: 351-354.

52 Zimmermann $H$. Extracellular metabolism of ATP and other nucleotides. Naunyn Schmiedebergs Arch Pharmacol 2000; 362: 299-309.

53 Gendron F.P., Benrezzak O., Krugh B.W., Kong Q., Weisman G.A. and Beaudoin A.R. Purine signaling and potential new therapeutic approach: possible outcomes of NTPDase inhibition. Curr Drug Targets 2002; 3: 229-245.

54 Burnstock G. and Knight G.E. Cellular distribution and functions of P2 receptor subtypes in different systems. Int Rev Cytol 2004; 240: 31-304.

55 von Kugelgen I. and Wetter A. Molecular pharmacology of P2Y-receptors. Naunyn Schmiedebergs Arch Pharmacol 2000; 362: 310-323.

56 Communi D., Janssens R., Suarez-Huerta N., Robaye B. and Boeynaems J.M. Advances in signalling by extracellular nucleotides. the role and transduction mechanisms of P2Y receptors. Cell Signal 2000; 12: 351-360.

57 Ralevic V. and Burnstock G. Receptors for purines and pyrimidines. Pharmacol Rev 1998; 50: 413-492.

58 Burnstock G. and Williams M. P2 purinergic receptors: modulation of cell function and therapeutic potential. J Pharmacol Exp Ther 2000; 295: 862-869.

59 Communi D., Robaye B. and Boeynaems J.M. Pharmacological characterization of the human P2Y11 receptor. Br J Pharmacol 1999; 128: 1199-1206.

60 Khakh B.S., Burnstock G., Kennedy C., King B.F., North R.A., Seguela P., Voigt M. and Humphrey P.P. International union of pharmacology. XXIV. Current status of the nomenclature and properties of P2X receptors and their subunits. Pharmacol Rev 2001; 53: 107-118.

61 North R.A. Molecular physiology of P2X receptors. Physiol Rev 2002; 82: 1013-1067.

62 Fredholm B.B., AP I.J., Jacobson K.A., Klotz K.N. and Linden J. International Union of Pharmacology. XXV. Nomenclature and classification of adenosine receptors. Pharmacol Rev 2001; 53: 527-552.

63 Muller C.E. Medicinal chemistry of adenosine A3 receptor ligands. Curr Top Med Chem 2003; 3: $445-462$.

64 Marteau F., Le Poul E., Communi D., Labouret C., Savi P., Boeynaems J.M. and Gonzalez N.S. Pharmacological characterization of the human P2Y13 receptor. Mol Pharmacol 2003; 64: 104-112.

65 Brunschweiger A. and Muller C.E. P2 receptors activated by uracil nucleotides--an update. Curr Med Chem 2006; 13: 289-312.

66 Van der Vliet A. and Bast A. Effect of oxidative stress on receptors and signal transmission. Chem Biol Interact 1992; 85: 95-116.

67 Tsai K.L., Wang S.M., Chen C.C., Fong T.H. and Wu M.L. Mechanism of oxidative stressinduced intracellular acidosis in rat cerebellar astrocytes and C6 glioma cells. J Physiol 1997; 502 ( Pt 1): 161-174.

68 Yoo B.K., Choi J.W., Yoon S.Y. and Ko K.H. Protective effect of adenosine and purine nucleos $(\mathrm{t})$ ides against the death by hydrogen peroxide and glucose deprivation in rat primary astrocytes. Neurosci Res 2005; 51: 39-44.

69 van Wijk S.J. and Hageman G.J. Poly(ADP-ribose) polymerase-1 mediated caspaseindependent cell death after ischemia/reperfusion. Free Radic Biol Med 2005; 39: 81-90.

70 Lee Y.W., Ha M.S. and Kim Y.K. H2O2-induced cell death in human glioma cells: role of lipid peroxidation and PARP activation. Neurochem Res 2001; 26: 337-343. 
71 Kourie J.I. Interaction of reactive oxygen species with ion transport mechanisms. Am J Physiol 1998; 275: C1-24.

72 Shinozaki Y., Koizumi S., Ishida S., Sawada J., Ohno Y. and Inoue K. Cytoprotection against oxidative stress-induced damage of astrocytes by extracellular ATP via P2Y(1) receptors. Glia 2005; 49: 288-300.

73 Kribben A., Feldkamp T., Horbelt M., Lange B., Pietruck F., Herget-Rosenthal S., Heemann U. and Philipp T. ATP protects, by way of receptor-mediated mechanisms, against hypoxiainduced injury in renal proximal tubules. $J$ Lab Clin Med 2003; 141: 67-73.

74 Lee Y.J., Lee J.H. and Han H.J. Extracellular adenosine triphosphate protects oxidative stress-induced increase of p21(WAF1/Cip1) and p27(Kip1) expression in primary cultured renal proximal tubule cells: Role of PI3K and Akt signaling. J Cell Physiol 2006; 209: 802-810.

75 Ahmad S., Ahmad A., McConville G., Schneider B.K., Allen C.B., Manzer R., Mason R.J. and White C.W. Lung epithelial cells release ATP during ozone exposure: signaling for cell survival. Free Radic Biol Med 2005; 39: 213-226.

76 Ahmad S., Ahmad A., Ghosh M., Leslie C.C. and White C.W. Extracellular ATP-mediated signaling for survival in hyperoxia-induced oxidative stress. J Biol Chem 2004; 279: 1631716325.

77 Koyama T., Oike M. and Ito Y. Involvement of Rho-kinase and tyrosine kinase in hypotonic stress-induced ATP release in bovine aortic endothelial cells. J Physiol 2001; 532: 759-769.

78 Gerasimovskaya E.V., Ahmad S., White C.W., Jones P.L., Carpenter T.C. and Stenmark K.R. Extracellular ATP is an autocrine/paracrine regulator of hypoxia-induced adventitial fibroblast growth. Signaling through extracellular signal-regulated kinase-1/2 and the Egr-1 transcription factor. J Biol Chem 2002; 277: 44638-44650.

79 Aderem A. and Underhill D.M. Mechanisms of phagocytosis in macrophages. Annu Rev Immunol 1999; 17: 593-623.

80 Roos D., van Bruggen R. and Meischl C. Oxidative killing of microbes by neutrophils. Microbes Infect 2003; 5: 1307-1315.

81 Zhang Y., Palmblad J. and Fredholm B.B. Biphasic effect of ATP on neutrophil functions mediated by P2U and adenosine A2A receptors. Biochem Pharmacol 1996; 51: 957-965.

82 Parvathenani L.K., Tertyshnikova S., Greco C.R., Roberts S.B., Robertson B. and Posmantur R. P2X7 mediates superoxide production in primary microglia and is up-regulated in a transgenic mouse model of Alzheimer's disease. J Biol Chem 2003; 278: 13309-13317.

83 Fredholm B.B. Purines and neutrophil leukocytes. Gen Pharmacol 1997; 28: 345-350.

84 Murphy J.K., Livingston F.R., Gozal E., Torres M. and Forman H.J. Stimulation of the rat alveolar macrophage respiratory burst by extracellular adenine nucleotides. Am J Respir Cell Mol Biol 1993; 9: 505-510.

85 Nakanishi M., Takihara H., Minoru Y. and Yagawa K. Extracellular ATP itself elicits superoxide generation in guinea pig peritoneal macrophages. FEBS Lett 1991; 282: 91-94.

86 Schmid-Antomarchi H., Schmid-Alliana A., Romey G., Ventura M.A., Breittmayer V., Millet M.A., Husson H., Moghrabi B., Lazdunski M. and Rossi B. Extracellular ATP and UTP control the generation of reactive oxygen intermediates in human macrophages through the opening of a charybdotoxin-sensitive Ca2+-dependent K+ channel. J Immunol 1997; 159: 6209-6215.

87 Sperlagh B., Hasko G., Nemeth Z. and Vizi E.S. ATP released by LPS increases nitric oxide production in raw 264.7 macrophage cell line via P2Z/P2X7 receptors. Neurochem Int 1998; 33: $209-215$.

88 Guerra A.N., Fisette P.L., Pfeiffer Z.A., Quinchia-Rios B.H., Prabhu U., Aga M., Denlinger L.C., Guadarrama A.G., Abozeid S., Sommer J.A., Proctor R.A. and Bertics P.J. Purinergic receptor regulation of LPS-induced signaling and pathophysiology. J Endotoxin Res 2003; 9: 256-263. 
89 Aga M., Watters J.J., Pfeiffer Z.A., Wiepz G.J., Sommer J.A. and Bertics P.J. Evidence for nucleotide receptor modulation of cross talk between MAP kinase and NF-kappa B signaling pathways in murine RAW 264.7 macrophages. Am J Physiol Cell Physiol 2004; 286: C923930.

90 Di Virgilio F., Chiozzi P., Ferrari D., Falzoni S., Sanz J.M., Morelli A., Torboli M., Bolognesi G. and Baricordi O.R. Nucleotide receptors: an emerging family of regulatory molecules in blood cells. Blood 2001; 97: 587-600.

91 Di Virgilio F., Ferrari D., Idzko M., Panther E., Norgauer J., la Sala A. and Girolomoni G. Extracellular ATP, P2 receptors, and inflammation. drug development research 2003; 59: 171 . 174.

92 Bours M.J., Swennen E.L., Di Virgilio F., Cronstein B.N. and Dagnelie P.C. Adenosine 5'triphosphate and adenosine as endogenous signaling molecules in immunity and inflammation. Pharmacol Ther 2006; 112: 358-404.

93 Agteresch H.J., Dagnelie P.C., van den Berg J.W. and Wilson J.H. Adenosine triphosphate: established and potential clinical applications. Drugs 1999; 58: 211-232.

94 Rapaport E. Treatment of human tumour cells with ADP or ATP yields arrest of growth in the S phase of the cell cycle. J Cell Physiol 1983; 114: 279-283.

95 Agteresch H.J., Van Rooijen M., van den Berg J., Minderman-voortman G., Wilson J.H. and Dagnelie P.C. Growth inhibition of lung cancer cells by adenosine 5'-triphosphate. drug development research 2003; 60: 196-203.

96 Yamada T., Okajima F., Akbar M., Tomura H., Narita T., Ohwada S., Morishita Y. and Kondo $\mathrm{Y}$. Cell cycle arrest and the induction of apoptosis in pancreatic cancer cells exposed to adenosine triphosphate in vitro. Oncol Rep 2002; 9: 113-117.

97 Conigrave A.D., van der Weyden L., Holt L., Jiang L., Wilson P., Christopherson R.I. and Morris M.B. Extracellular ATP-dependent suppression of proliferation and induction of differentiation of human HL-60 leukemia cells by distinct mechanisms. Biochem Pharmacol 2000; 60: 1585-1591.

98 White N. and Burnstock G. P2 receptors and cancer. Trends Pharmacol Sci 2006; 27: $211-$ 217.

99 Rapaport E. Experimental cancer therapy in mice by adenine nucleotides. Eur J Cancer Clin Oncol 1988; 24: 1491-1497.

100 Rapaport E. Mechanisms of anticancer activities of adenine nucleotides in tumour-bearing hosts. Ann N Y Acad Sci 1990; 603: 142-149; discussion 149-150.

101 Lasso de la Vega M.C., Terradez P., Obrador E., Navarro J., Pellicer J.A. and Estrela J.M. Inhibition of cancer growth and selective glutathione depletion in Ehrlich tumour cells in vivo by extracellular ATP. Biochem J 1994; 298 ( Pt 1): 99-105.

102 Kitagawa T. and Akamatsu Y. Modulation of passive permeability by external ATP and cytoskeleton-attacking agents in cultured mammalian cells. Biochim Biophys Acta 1983; 734: 25-32.

103 Mure T., Sano K. and Kitagawa T. Modulation of membrane permeability, cell proliferation and cytotoxicity of antitumour agents by external ATP in mouse tumour cells. Jpn J Cancer Res 1992; 83: 121-126.

104 Hatta Y., Takahashi M., Enomoto Y., Takahashi N., Sawada U. and Horie T. Adenosine triphosphate (ATP) enhances the antitumour effect of etoposide (VP16) in lung cancer cells. Oncol Rep 2004; 12: 1139-1142.

105 Obrador E., Navarro J., Mompo J., Asensi M., Pellicer J.A. and Estrela J.M. Glutathione and the rate of cellular proliferation determine tumour cell sensitivity to tumour necrosis factor in vivo. Biochem J 1997; 325 ( Pt 1): 183-189. 
106 Estrela J.M., Obrador E., Navarro J., Lasso De la Vega M.C. and Pellicer J.A. Elimination of Ehrlich tumours by ATP-induced growth inhibition, glutathione depletion and X-rays. Nat Med 1995; 1: 84-88.

107 Szeinfeld D. and De Villiers N. Radioprotective properties of ATP and modification of acid phosphatase response after a lethal dose of whole body $\mathrm{p}(66 \mathrm{MeV}) / \mathrm{Be}$ neutron radiation to BALB/c mice. Cancer Biochem Biophys 1992; 13: 123-132.

108 Szeinfeld D. and de Villiers N. Response of normal BALB/c mouse tissue to $p(66 \mathrm{MeV}) / \mathrm{Be}$ fast neutron radiation: protection by exogenous ATP. Strahlenther Onkol 1992; 168: 174-178.

109 Senagore A.J., Milsom J.W., Walshaw R.K., Mostoskey U., Dunstan R. and Chaudry I.H. Adenosine triphosphate-magnesium chloride in radiation injury. Surgery 1992; 112: 933-939.

110 Haskell C.M., Mendoza E., Pisters K.M., Fossella F.V. and Figlin R.A. Phase II study of intravenous adenosine 5 '-triphosphate in patients with previously untreated stage IIIB and stage IV non-small cell lung cancer. Invest New Drugs 1998; 16: 81-85.

111 Haskell C.M., Wong M., Williams A. and Lee L.Y. Phase I trial of extracellular adenosine 5'triphosphate in patients with advanced cancer. Med Pediatr Oncol 1996; 27: 165-173.

112 Agteresch H.J., Dagnelie P.C., van der Gaast A., Stijnen T. and Wilson J.H. Randomized clinical trial of adenosine 5 '-triphosphate in patients with advanced non-small-cell lung cancer. J Natl Cancer Inst 2000; 92: 321-328.

113 Agteresch H.J., Burgers S.A., van der Gaast A., Wilson J.H. and Dagnelie P.C. Randomized clinical trial of adenosine 5'-triphosphate on tumour growth and survival in advanced lung cancer patients. Anticancer Drugs 2003; 14: 639-644.

114 Agteresch H.J., Rietveld T., Kerkhofs L.G., van den Berg J.W., Wilson J.H. and Dagnelie P.C. Beneficial effects of adenosine triphosphate on nutritional status in advanced lung cancer patients: a randomized clinical trial. $J$ Clin Oncol 2002; 20: 371-378. 


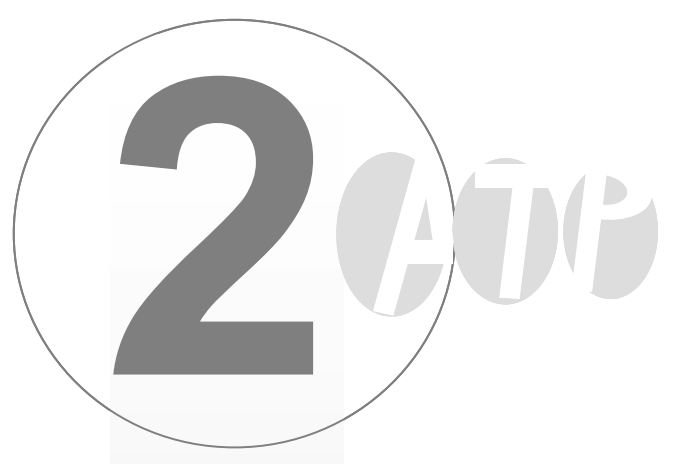

Immunoregulatory effects of ATP on cytokine release from stimulated whole blood

Els L.R. Swennen

Aalt Bast

Pieter C. Dagnelie

European Journal of Immunology 2005; 35: 852-858 


\begin{abstract}
In vitro studies suggest that extracellular nucleotides and nucleosides may be important regulators of inflammatory and immune responses. Most studies with adenosine 5'-triphosphate (ATP) have been performed in cell lines, which are remote from the human situation. The purpose of the present study was to determine the effects of ATP on tumour necrosis factor-alpha (TNF- $\alpha$ ), interleukin (IL)-6 and IL-10 release in stimulated whole blood. Blood samples were drawn from healthy volunteers and incubated with ATP and lipopolysaccharide (LPS) + phytohemagglutinin (PHA) for $24 \mathrm{~h}$. Contrary to expectations, ATP at $100 \mu \mathrm{M}$ and $300 \mu \mathrm{M}$ induced a reduction in TNF- $\alpha$ secretion by $32 \pm 8 \%$ (mean \pm SEM) and $65 \pm$ $4 \%$, respectively. Furthermore, these ATP concentrations induced an increase in IL10 secretion by $93 \pm 56 \%$ and $166 \pm 71 \%$ in whole blood, respectively. The ATP analogue adenosine 5'-O-(3-thiotriphosphate) (ATP $\gamma \mathrm{S}$ ) and adenosine 5'diphosphate (ADP) also inhibited TNF- $\alpha$ release, but only ADP showed also a stimulatory effect on IL-10. Co-treatment with adenosine deaminase did not reverse the ATP effect on TNF- $\alpha$ and IL-10. These results show, for the first time, that ATP inhibits the inflammatory response in stimulated whole blood as indicated by inhibition of TNF- $\alpha$ and stimulation of $\mathrm{IL}-10$ release and that this effect is predominantly mediated by ATP and not by adenosine.
\end{abstract}




\section{Introduction}

Over the past decades, evidence has accumulated which indicates that extracellular nucleotides and nucleosides may be important regulators of inflammatory and immune responses in cell lines [1]. Generally speaking, adenosine 5'-triphosphate (ATP) is thought to exert immune-stimulating, pro-inflammatory effects [2-5], whereas adenosine has both pro- and anti-inflammatory effects [6-9]. However, these in vitro data are not directly applicable to the human in vivo situation, and human data in this field are lacking so far.

A recent randomized clinical trial [10] showed that in patients with advanced (stage IIIB/IV) non-small-cell lung cancer (NSCLC), regular infusions of ATP induced a marked amelioration of weight, muscle strength and quality of life compared to a control group of patients receiving usual palliative care only. Moreover, in a subgroup of weight-losing patients, ATP-treatment induced a marked increase in survival relative to the control group (9.3 vs. 3.5 months) [11]. Although kinetic studies in a subgroup of cancer patients demonstrated significant repletion of intracellular ATP levels in both erythrocytes [12] and the liver [13], this could not explain the dramatic clinical effects of ATP due to the short half-life of ATP $(6 \mathrm{~h}$ in erythrocytes). Therefore, we hypothesized that immunomodulatory properties of ATP described in vitro might be involved in the observed effects of ATP.

The aim of this study was to determine the influence of ATP on cytokine secretion in whole blood cell cultures from healthy subjects, a model closely resembling the in vivo situation. A combination of lipopolysaccharide (LPS) and phytohemagglutinin (PHA) was used to stimulate monocytes and to activate $T$ cells and natural killer (NK) cells respectively.

\section{Materials and methods}

\section{Chemicals}

Purified PHA HA16 was from Murex, Dartford, UK. Adenosine 5'-diphosphate (ADP), uridine 5'-triphosphate (UTP), adenosine deaminase, adenosine 5'-O-(3thiotriphosphate) (ATP $\gamma \mathrm{S}$ ) and LPS (E. Coli 0.26:B6) were purchased from Sigma Chemical Co, St. Louis, USA. Human tumour necrosis factor-alpha (TNF- $\alpha)(7300$ $\mathrm{pg} / \mathrm{ml})$, human interleukin (IL)-10 (4000 pg/ml) and human IL-6 (4500 pg/ml) were obtained from CLB/Sanquin, The Netherlands. RPMI 1640 medium containing Lglutamine was obtained from Gibco, UK. ATP was purchased from Calbiochem, USA. 


\section{Blood based cytokine production assay}

Blood was collected from eight healthy volunteers (age range: 25-45 years; six women and three men) in heparin containing vacutainer tubes (Vacutainer, BectonDickinson, $170 \mathrm{I} . \mathrm{U}$ ). The storage time (up to $4 \mathrm{~h}$ ) and the storage temperature (room temperature or ice) of the blood had no influence on the measured values of the cytokines, which confirms the stability of the assay (see results). In all the experiments, blood was stored on ice and the incubations were started within one hour after blood collection. Whole blood was aliquoted into 24 -well sterile plates and diluted 1:4 with RPMI 1640 (supplemented with L-glutamine). To induce cytokine production, PHA and bacterial LPS were added to whole blood at $1 \mu \mathrm{g} / \mathrm{ml}$ and 10 $\mu \mathrm{g} / \mathrm{ml}$ respectively. After addition of the stimulants, the plates were incubated in $5 \%$ $\mathrm{CO}_{2}$ at $37^{\circ} \mathrm{C}$ for $24 \mathrm{~h}$. Cell-free supernatant fluids were then collected by centrifugation $\left(6000 \mathrm{rpm}, 10 \mathrm{~min}\right.$ at $\left.4^{\circ} \mathrm{C}\right)$ and stored at $-20^{\circ} \mathrm{C}$ until tested for presence of cytokines.

\section{Incubation conditions}

Blood was pre-incubated with ATP, ADP, UTP and ATP $\gamma \mathrm{S}$ at $5 \% \mathrm{CO}_{2}$ at $37^{\circ} \mathrm{C}$ for 30 min before stimulation with LPS + PHA for $24 \mathrm{~h}$. The incubation with adenosine deaminase was started 15 min before the addition of medium (control) or ATP. All the used compounds were dissolved in RPMI 1640 culture medium. ATP was added to the blood at a final concentration of 1-300 $\mu \mathrm{M}$ in the first $30 \mathrm{~min}$ incubation step. ADP, UTP and ATP $\gamma S$ were added at a final concentration of $300 \mu \mathrm{M}$ in the first 30 min incubation step and adenosine deaminase was added at a final concentration of $0.01 \mathrm{U} / \mathrm{ml}-10 \mathrm{U} / \mathrm{ml}$. All incubations were performed in duplicate.

\section{Enzyme linked immune sorbent assay (ELISA) measurement}

All cytokines were quantified by means of PeliKine Compact human ELISA kits (CLB/Sanquin, The Netherlands), based on appropriate and validated sets of monoclonal antibodies. Assays were performed as described by the manufacturer's instructions. Specific monoclonal antibodies were pre-coated overnight at room temperature in 96-well polystyrene microtiter plates. Standards and samples were pipetted into the wells. Subsequently, a biotinylated second monoclonal antibody was added and incubated. Following a washing to remove unbound antibodyenzyme reagents, horseradish peroxidase (HRP)-conjugated streptavidin, which binds onto the biotinylated side of the cytokine complex, was added to the wells. After removal of non-bound HRP conjugate by washing, a substrate solution was added to the wells. Color development was stopped by addition of sulfuric acid and the intensity of the color was measured by a microtiter plate reader. 


\section{Statistics}

The effect of different concentrations of the tested compounds and the effect of the storage conditions on cytokine release in whole blood were compared to the control condition (no ATP) using Wilcoxon's signed rank test. Spearman's rank correlation coefficient was used to appraise the relation between the effects of ATP on TNF- $\alpha$ and IL-10 release. Two-tailed P-values of 0.05 or less were considered statistically significant. Results are reported as means \pm SEM.

\section{Results}

\section{Influence of blood storage conditions}

To examine the stability of the blood samples, LPS + PHA stimulation was performed in blood samples of four healthy volunteers. The blood was stored at room temperature or on ice, during 1, 2, 3 and $4 \mathrm{~h}$ before stimulating the blood. All supernatants were analyzed in a single ELISA batch. As shown in table 1, there was no significant effect of the different storage times and temperatures on the TNF- $\alpha$ and IL-10 concentrations for samples with delays from $1 \mathrm{~h}$ to $4 \mathrm{~h}$ and for storage at room temperature or ice for $1 \mathrm{~h}$ and $4 \mathrm{~h}$.

Table 1: Influence of storage time and temperature (room temperature or ice) of whole blood on the production of TNF- $\alpha$ and IL-10 upon incubation with LPS + PHA ${ }^{\text {a) }}$.

\begin{tabular}{llllll}
\hline Storage conditions & TNF- $\alpha$ & & & IL-10 & \\
\cline { 2 - 3 } & $\begin{array}{l}\text { Mean } \\
(\mathrm{pg} / \mathrm{ml})\end{array}$ & $\begin{array}{l}\text { SEM } \\
(\mathrm{pg} / \mathrm{ml})\end{array}$ & & $\begin{array}{l}\text { Mean } \\
(\mathrm{pg} / \mathrm{ml})\end{array}$ & $\begin{array}{l}\text { SEM } \\
(\mathrm{pg} / \mathrm{ml})\end{array}$ \\
\hline 1h RT & 3328 & 75 & & 4785 & 1514 \\
1h ice & 3001 & 67 & & 4423 & 1359 \\
2h RT & 3290 & 121 & & 3430 & 978 \\
3h RT & 3493 & 130 & & 3829 & 1110 \\
4h RT & 3551 & 179 & & 3597 & 898 \\
4h ice & 3504 & 164 & & 3569 & 920 \\
\hline
\end{tabular}

a) Data are shown as mean \pm SEM in four subjects (RT = room temperature).

\section{Effect of ATP on cytokine release from LPS + PHA-stimulated whole blood}

To determine the effects of ATP on the cytokine production in whole blood, individual blood samples from eight healthy volunteers were incubated with medium (control) or ATP for 30 min and then treated with or without LPS + PHA for $24 \mathrm{~h}$. 
In unstimulated whole blood, concentrations of TNF- $\alpha$, IL-10 and IL- 6 were $0.26 \pm$ $0.06 \mathrm{pg} / \mathrm{ml}$ (mean \pm SEM), $0.29 \pm 0.08 \mathrm{pg} / \mathrm{ml}$, and $35 \pm 18 \mathrm{pg} / \mathrm{ml}$, respectively (Table 2). Addition of ATP to unstimulated whole blood did not result in significant changes in the release of TNF- $\alpha$, IL-10 and IL-6 (data not shown).

Addition of LPS + PHA in the absence of ATP caused a significant increase in TNF$\alpha, \mathrm{IL}-10$ and IL-6 release to $7705 \pm 2981 \mathrm{pg} / \mathrm{ml}, 2702 \pm 1184 \mathrm{pg} / \mathrm{ml}$ and $20229 \pm 755$ $\mathrm{pg} / \mathrm{ml}$, respectively (Table 2 ).

Table 2: Effect of LPS + PHA stimulation on the release of TNF- $\alpha$, IL-10 and IL-6 from whole blood a).

\begin{tabular}{|c|c|c|c|c|c|c|}
\hline Condition & TNF- $\alpha$ & & IL-10 & & IL-6 & \\
\hline & $\begin{array}{l}\text { Mean } \\
(\mathrm{pg} / \mathrm{ml})\end{array}$ & $\begin{array}{l}\text { SEM } \\
(\mathrm{pg} / \mathrm{ml})\end{array}$ & $\begin{array}{l}\text { Mean } \\
(\mathrm{pg} / \mathrm{ml})\end{array}$ & $\begin{array}{l}\text { SEM } \\
(\mathrm{pg} / \mathrm{ml})\end{array}$ & $\begin{array}{l}\text { Mean } \\
(\mathrm{pg} / \mathrm{ml})\end{array}$ & $\begin{array}{l}\text { SEM } \\
(\mathrm{pg} / \mathrm{ml})\end{array}$ \\
\hline Unstimulated & 0.27 & 0.06 & 0.29 & 0.08 & 35 & 12 \\
\hline Stimulated & $7705^{*}$ & 2981 & $2702^{*}$ & 1184 & $20299^{*}$ & 1850 \\
\hline
\end{tabular}

a) Data are shown as mean \pm SEM in eight subjects. ${ }^{*} \mathrm{P}<0.05$ between the stimulated and unstimulated condition.

The effect of addition of different ATP concentrations to LPS + PHA-stimulated whole blood on TNF- $\alpha$ production is shown in figure 1.

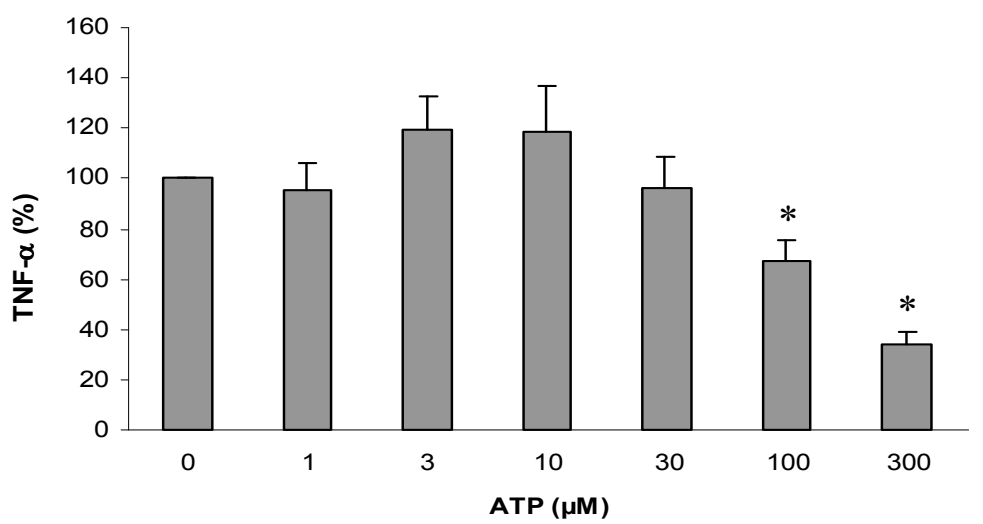

Figure 1: Effect of ATP on LPS + PHA-induced TNF- $\alpha$ secretion in whole blood from eight healthy subjects. The whole blood was incubated with the indicated final concentrations of ATP during an initial $30 \mathrm{~min}$ incubation step followed by exposure to LPS and PHA for $24 \mathrm{~h}$. Results are expressed in percentage, with $100 \%$ representing TNF- $\alpha$ release under stimulation by LPS + PHA in the absence of ATP. ${ }^{*} \mathrm{P}=0.01$ compared to LPS + PHA stimulation without ATP. Data are expressed as mean \pm SEM. 
At an ATP concentration of $100 \mu \mathrm{M}$, a $32 \pm 8 \%$ inhibition of TNF- $\alpha$ production was observed, and at $300 \mu \mathrm{M}$, the attenuation of TNF- $\alpha$ production was $65 \pm 4 \%$. The above effects were consistent in all subjects. The apparent increase of TNF- $\alpha$ at 3 and $10 \mu \mathrm{M}$ of ATP was due to one subject with a marked increase in the TNF- $\alpha$ concentration at only these two ATP concentrations. The difference in TNF- $\alpha$ release between the ATP-doses of 100 and $300 \mu \mathrm{M}$ was statistically significant and consistent in all subjects.

The effect of addition of different ATP concentrations to LPS + PHA-stimulated whole blood on IL-10 levels is shown in figure 2.

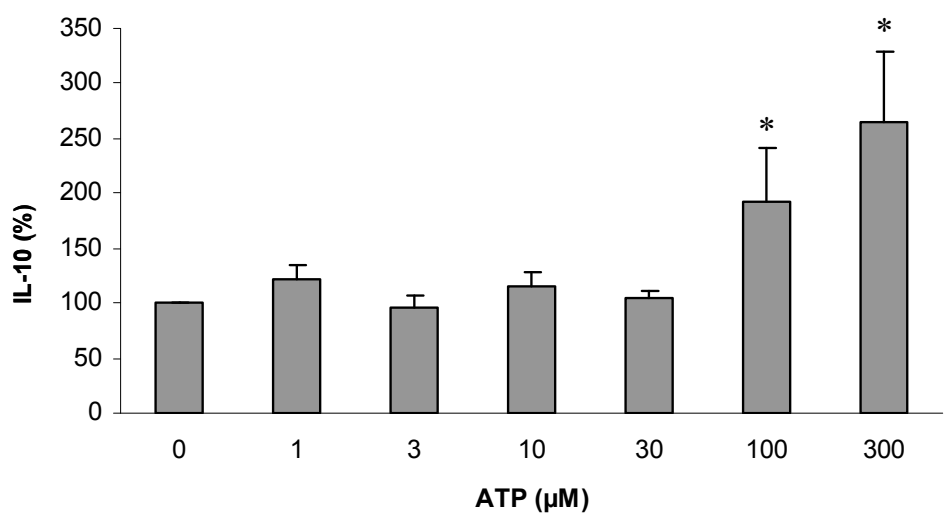

Figure 2: Effect of ATP on LPS + PHA-induced IL-10 secretion in whole blood from eight healthy subjects. The whole blood was incubated with the indicated final concentrations of ATP during an initial 30 min incubation step followed by exposure to LPS and PHA for $24 \mathrm{~h}$. Results are expressed in percentage, with $100 \%$ representing IL-10 release under stimulation by LPS + PHA in the absence of ATP. ${ }^{*} \mathrm{P}=0.01$ compared to LPS + PHA stimulation without ATP. Data are expressed as mean \pm SEM.

At ATP concentrations of 100 and $300 \mu \mathrm{M}$, we observed a rise in IL-10 production by $93 \pm 56 \%$ and $166 \pm 71 \%$, respectively. Again, the difference in IL-10 release between the ATP-doses of 100 and $300 \mu \mathrm{M}$ was statistically significant and consistent in all subjects.

In contrast to TNF- $\alpha$ and IL-10, ATP did not significantly alter the production of IL-6 (data not shown).

As shown in figure 3, a significant linear relationship between the effects of ATP on TNF- $\alpha$ and IL-10 release in stimulated blood was found. 


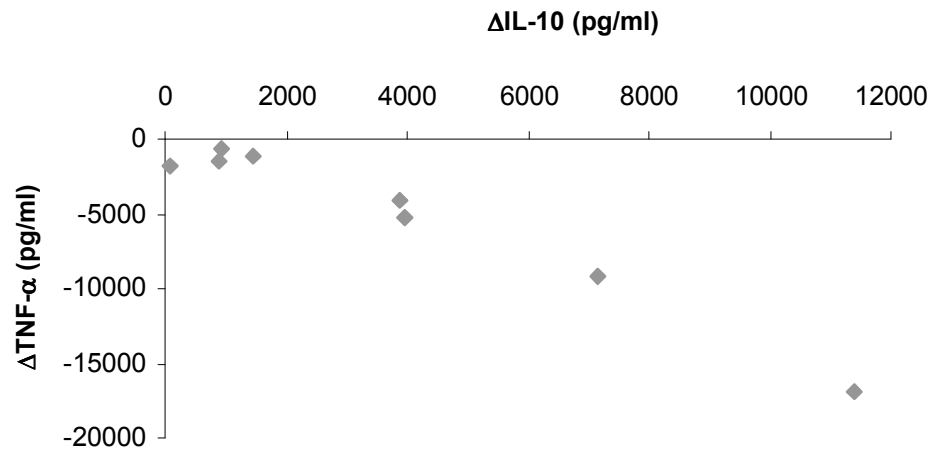

Figure 3: The relationship between TNF- $\alpha$ and IL-10 secretions in LPS + PHA-stimulated whole blood. The inhibition of the TNF- $\alpha$ release by ATP is related to the stimulation of IL-10 release by ATP $(r=-0.786, P=0.02)$. Results are expressed as the difference in cytokine release at $300 \mu \mathrm{M}$ ATP compared to control (no ATP, $n=8$ ).

As shown in table 3, the stable ATP analogue ATP $\gamma \mathrm{S}$ also significantly inhibited TNF- $\alpha$ release. However, ATP $\gamma$ S showed no effect on IL-10 release. ADP showed effects similar to ATP, i.e. a significant inhibitory effect on TNF- $\alpha$ release and a significant stimulatory effect on IL-10 release.

Table 3: Effect of $300 \mu \mathrm{M}$ ATP, ATP $\gamma \mathrm{S}$, ADP and UTP on LPS + PHA-induced TNF- $\alpha$ and IL-10 release in whole blood ${ }^{\text {a) }}$.

\begin{tabular}{lll}
\hline & TNF- $\alpha(\%)$ & IL-10 (\%) \\
\hline Control & 100 & 100 \\
ATP & $70.3 \pm 3.9^{*}$ & $147.6 \pm 7.5^{*}$ \\
ATP $\gamma$ S & $66.5 \pm 6.0^{*}$ & $101.8 \pm 5.1$ \\
ADP & $78.9 \pm 2.7^{*+}$ & $135.3 \pm 6.5^{*}$ \\
UTP & $102.6 \pm 6.4$ & $100.4 \pm 7.1$ \\
\hline
\end{tabular}

a) Data are expressed as percentage, with $100 \%$ representing the cytokine release in the presence of medium (control), and are shown as mean \pm SEM in six subjects. ${ }^{*} \mathrm{P}<0.05$ compared to control (medium); ${ }^{+} \mathrm{P}<0.05$ compared to effect of ATP. 
The inhibition of TNF- $\alpha$ release by ADP was significantly less when compared with ATP; as for the effect on IL-10 release, there was no significant difference between ATP and ADP. UTP, in contrast, had no effect on TNF- $\alpha$ and IL-10 release.

Since extracellular ATP is rapidly metabolized to adenosine, a substance which is able to suppress the production of pro-inflammatory cytokines, we also investigated the possibility that adenosine might be involved in the ATP effect on cytokine release. To remove the adenosine produced by the degradation of ATP, we cotreated the cells with adenosine deaminase for $15 \mathrm{~min}$ before adding medium (control) or ATP. When adenosine deaminase was added at different concentrations, in combination with ATP, the effect of ATP on TNF- $\alpha$ and IL-10 release remained and was not significantly different from the effect of ATP as such (Table 4), indicating that the effects of ATP on TNF- $\alpha$ and IL-10 release are not due to the breakdown product adenosine.

Table 4: Effect of co-treatment with adenosine deaminase (ADA) on the effect of ATP (300 $\mu \mathrm{M})$ on TNF- $\alpha$ and IL-10 release ${ }^{\text {a) }}$.

\begin{tabular}{|c|c|c|}
\hline Condition & TNF- $\alpha(\%)$ & IL-10 (\%) \\
\hline ATP $^{\text {b) }}$ & $70.3 \pm 3.9$ & $147.6 \pm 7.5$ \\
\hline $0.01 \mathrm{U} / \mathrm{ml}$ ADA + ATP ${ }^{\mathrm{c})}$ & $80.2 \pm 10.9$ & $143.4 \pm 8.7$ \\
\hline $0.1 \mathrm{U} / \mathrm{ml} \mathrm{ADA}+\mathrm{ATP}^{\mathrm{c})}$ & $71.7 \pm 10.2$ & $134.8 \pm 10.7$ \\
\hline $1 \mathrm{U} / \mathrm{ml}$ ADA + ATP ${ }^{\mathrm{c})}$ & $81.9 \pm 7.4$ & $149.8 \pm 11.4$ \\
\hline $10 \mathrm{U} / \mathrm{ml} \mathrm{ADA}+\mathrm{ATP}^{\mathrm{c})}$ & $76.7 \pm 4.2$ & $136.2 \pm 10.2$ \\
\hline
\end{tabular}

a) Data are shown as mean \pm SEM in six subjects; ${ }^{\text {b) }}$ Results are expressed as percentage, with $100 \%$ representing TNF- $\alpha$ or IL-10 release in the absence of ATP; ${ }^{c}$ Results are expressed as percentage, with $100 \%$ representing TNF- $\alpha$ or IL-10 release in the presence of different concentrations of ADA in the absence of ATP.

\section{Discussion}

Production of the cytokines TNF- $\alpha, \mathrm{IL}-6$ and $\mathrm{IL}-10$ is part of the human immune reaction, which is involved in a number of chronic inflammatory diseases, including cancer. TNF- $\alpha$, a pro-inflammatory cytokine, is produced by macrophages and monocytes in response to inflammatory stimuli including LPS [14, 15]. In contrast to TNF- $\alpha$, IL-10 is an anti-inflammatory cytokine with immunosuppressive properties, and is among others produced by activated T cells [15-17]. IL-6 is a cytokine produced by monocytes, T-lymphocytes, and fibroblasts, and although IL-6 displays several pro-inflammatory properties, anti-inflammatory properties of this cytokine have also been reported $[14,15]$. 
In this study, we tested the effect of ATP on the release of the cytokines TNF- $\alpha$, IL10 , and IL-6 in human LPS + PHA-stimulated whole blood ex vivo, a model not previously used for studying the immunomodulatory properties of ATP. Results show that ATP consistently suppresses TNF- $\alpha$ release and stimulates IL-10 secretion in LPS + PHA-stimulated whole blood in a dose-dependent manner. In contrast, ATP had no effect on IL-6 release. The results of this study indicate that, in contrast with studies in isolated cells [2-5], ATP inhibits the acute inflammatory response through suppression of TNF- $\alpha$ and stimulation of IL-10 secretion in stimulated whole blood.

In contrast with studies in isolated cells or cell lines grown in medium, the utilized whole blood model stimulated with LPS + PHA closely resembles the in vivo situation and forms an appropriate and reproducible culture condition to measure cytokine production ex vivo [18]. In diluted whole blood, the natural cell-to-cell interactions are preserved and all blood components are present in in vivo ratios with non-cellular components. Therefore, this system is a good reflection of the natural environment [18]. The combined LPS + PHA stimulation allows the functional characterization of both the monocytic and T lymphocytic cytokines [19]. LPS mainly stimulates monocytes through CD14 and is a polyclonal mitogen for Blymphocytes. PHA, a common T cell mitogen, was used as a second stimulator to ensure the stimulation of T cells. Tests of the stability of blood prior to LPS + PHA stimulation showed that the temperature (room temperature vs. ice) and storage time $(1 \mathrm{~h}-4 \mathrm{~h})$ had no effect on the TNF- $\alpha$ and IL-10 release from LPS + PHAstimulated whole blood.

Numerous in vitro studies indicate that ATP mainly exerts immune-stimulating and pro-inflammatory effects in isolated immune cells and cell lines [1-5, 20]. Grahames et al. [3] showed the involvement of the $P 2 X_{7}$ receptor in ATP induced IL-1 $\beta$ release in LPS-stimulated human monocytes. Also in LPS-primed microglia it was shown that the addition of millimolar concentrations of extracellular ATP caused a release of a large amount of processed IL-1 $\beta$ [2]. In human dendritic cells, ATP caused a stimulation of $\mathrm{IL}-1 \beta$ and $\mathrm{TNF}-\alpha$, possibly by stimulation of the $\mathrm{P} 2 \mathrm{X}_{7}$ receptor [5]. Another pro-inflammatory effect of ATP is the activation of nuclear factor kappaB (NFKB) in LPS-stimulated microglial cells [20]. The receptor involved in these proinflammatory effects of ATP is probably the $\mathrm{P} 2 \mathrm{X}_{7}$ purinoceptor. This receptor is an unusual, bifunctional plasma membrane receptor, that upon transient stimulation with ATP behaves as a typical cation-selective ion channel permeable to $\mathrm{K}^{+}, \mathrm{Na}^{+}$, and $\mathrm{Ca}^{2+}[2,21,22]$.

The mechanism whereby ATP exerts anti-inflammatory effects in whole blood remains to be elucidated. The effect of ATP may be mediated by specific purinergic (P1 and $\mathrm{P} 2$ ) receptors, which are present on the surface of many cells. It has been known for some time that ATP-sensitive P2 purinergic receptors are expressed on immune cells and that activation of these receptors can alter immune cell function [1]. P2 receptors can be divided into two subfamilies: the G-protein-coupled P2Y 
receptors and the ligand-gated ion channel forming $\mathrm{P} 2 \mathrm{X}$ receptors [23]. The strong correlation between the TNF- $\alpha$ release and the IL-10 release from stimulated whole blood at $300 \mu \mathrm{m}$ ATP (as shown in figure 4) would suggest a possible common mechanism for the effect of ATP on TNF- $\alpha$ and IL-10.

Because ADP and UTP can be secreted by platelets, we also tested the effect of these compounds on cytokine release in stimulated whole blood. These compounds also give an indication about receptors potentially involved in the ATP effect. Results showed that ADP, similar to ATP, had an inhibitory effect on TNF- $\alpha$ and a stimulatory effect on IL-10 release. As ADP is a $P 2 Y_{1} / P_{2} Y_{12}$ agonist, this would suggest that these receptors might also be involved in the effect of ATP on TNF- $\alpha$ and $\mathrm{IL}-10$ release. In contrast, the $\mathrm{P}_{2} \mathrm{Y}_{2} / \mathrm{P}_{2} \mathrm{Y}_{4}$ agonist UTP had no effect on TNF- $\alpha$ and IL-10 release, indicating that these receptors are probably not involved in the ATP effect. Furthermore, to rule out the possibility that a breakdown product of ATP is involved in the effect of ATP, we tested the effect of the stable analogue ATP $\gamma \mathrm{S}$ on cytokine release. ATP $\gamma \mathrm{S}$, also known as a non-selective P2Y receptor agonist, inhibited TNF- $\alpha$ release but, in contrast to ATP, did not stimulate IL-10 release.

A study in cell cultures of isolated LPS-activated microglia [24], i.e. highly specialized neuronal macrophages, showed an inhibitory effect of ATP on release of TNF- $\alpha$, IL-6 and IL-1 $\beta$; IL-10 was not studied. The authors demonstrated that the inhibitory effect of ATP on cytokine release from these LPS-activated microglia was mediated via metabotropic receptors, more specific P2Y receptors. Duhant et al. demonstrated in isolated $\mathrm{CD} 4^{+} \mathrm{T}$ cells that several extracellular adenine nucleotides induced an increase in intracellular cyclic AMP (cAMP) thereby inhibiting cell activation in this in vitro model. The authors ascribed this effect to an unidentified P2Y receptor [25]. It is also a possibility that the anti-inflammatory effects of ATP are due to interference with the LPS pathway, for example by affecting the intracellular components of the inflammatory response to LPS such as the activation of p42/44 mitogen-activated protein kinases (MAPK) and p38 MAPK, or the phosphorylation of the c-Jun terminal kinase (JNK) [26-28].

Although ATP is primarily recognized by $\mathrm{P} 2$ receptors, the possibility that part of the observed anti-inflammatory effects of ATP are caused indirectly by degradation of ATP to AMP and adenosine should be taken into account, because adenosine is also known to alter cytokine production. Hasko et al. [6], reported that adenosine was able to suppress the production of IL-12 and TNF- $\alpha$ by stimulating $A_{2 a}$ and other adenosine receptors in isolated mouse macrophages. Several in vitro studies suggest that part of the effects of adenosine may be mediated by cAMP. Thus, stimulation of $A_{2 A}$ receptors present on immune cells may increase intracellular cAMP concentrations and, thereby, inhibit the immune response and inflammation by a series of coordinated actions [7, 29, 30]. The fact that, in our study, the coincubation with adenosine deaminase caused no reversal of the ATP effect on TNF$\alpha$ and IL-10 release, indicates that the effect of exogenous ATP on TNF- $\alpha$ and IL-10 
release is mainly mediated by direct effects of ATP on P2 receptors, and not via production of adenosine as a P1 agonist.

In conclusion, our results suggest that ATP could play an immunoregulatory role by inhibiting TNF- $\alpha$ and stimulating IL-10 release and, thereby, prevent excessive inflammation in immune-mediated diseases and cancer. Our data also support the hypothesis that the ATP effect on cytokine release in whole blood predominantly occurs via ATP itself, presumably via a P2Y receptor-coupled mechanism. Further research should be directed towards determination of the exact mechanism involved in the immunoregulatory effects of ATP. 


\section{References}

1 Di Virgilio F., Chiozzi P., Ferrari D., Falzoni S., Sanz J.M., Morelli A., Torboli M., Bolognesi G. and Baricordi O.R. Nucleotide receptors: an emerging family of regulatory molecules in blood cells. Blood 2001; 97: 587-600.

2 Ferrari D., Chiozzi P., Falzoni S., Hanau S. and Di Virgilio F. Purinergic modulation of interleukin-1 beta release from microglial cells stimulated with bacterial endotoxin. $J$ Exp Med 1997; 185: 579-582.

3 Grahames C.B., Michel A.D., Chessell I.P. and Humphrey P.P. Pharmacological characterization of ATP- and LPS-induced IL-1beta release in human monocytes. $\mathrm{Br} \mathrm{J}$ Pharmacol 1999; 127: 1915-1921.

4 Sanz J.M. and Di Virgilio F. Kinetics and mechanism of ATP-dependent IL-1 beta release from microglial cells. J Immunol 2000; 164: 4893-4898.

5 Ferrari D., La Sala A., Chiozzi P., Morelli A., Falzoni S., Girolomoni G., Idzko M., Dichmann S., Norgauer J. and Di Virgilio F. The P2 purinergic receptors of human dendritic cells: identification and coupling to cytokine release. Faseb J 2000; 14: 2466-2476.

6 Hasko G., Kuhel D.G., Chen J.F., Schwarzschild M.A., Deitch E.A., Mabley J.G., Marton A. and Szabo C. Adenosine inhibits IL-12 and TNF-[alpha] production via adenosine A2a receptor-dependent and independent mechanisms. Faseb J 2000; 14: 2065-2074.

7 Sitkovsky M.V. Use of the $\mathrm{A}(2 \mathrm{~A})$ adenosine receptor as a physiological immunosuppressor and to engineer inflammation in vivo. Biochem Pharmacol 2003; 65: 493-501.

8 Ritchie P.K., Spangelo B.L., Krzymowski D.K., Rossiter T.B., Kurth E. and Judd A.M. Adenosine increases interleukin 6 release and decreases tumour necrosis factor release from rat adrenal zona glomerulosa cells, ovarian cells, anterior pituitary cells, and peritoneal macrophages. Cytokine 1997; 9: 187-198.

9 Bouma M.G., Stad R.K., van den Wildenberg F.A. and Buurman W.A. Differential regulatory effects of adenosine on cytokine release by activated human monocytes. $J$ Immunol 1994; 153: 4159-4168.

10 Agteresch H.J., Dagnelie P.C., van der Gaast A., Stijnen T. and Wilson J.H. Randomized clinical trial of adenosine 5'-triphosphate in patients with advanced non-small-cell lung cancer. J Natl Cancer Inst 2000; 92: 321-328.

11 Agteresch H.J., Burgers S.A., van der Gaast A., Wilson J.H. and Dagnelie P.C. Randomized clinical trial of adenosine 5 '-triphosphate on tumour growth and survival in advanced lung cancer patients. Anticancer Drugs 2003; 14: 639-644.

12 Agteresch H.J., Dagnelie P.C., Rietveld T., van den Berg J.W., Danser A.H. and Wilson J.H. Pharmacokinetics of intravenous ATP in cancer patients. Eur J Clin Pharmacol 2000; 56: 4955.

13 Leij-Halfwerk S., Agteresch H.J., Sijens P.E. and Dagnelie P.C. Adenosine triphosphate infusion increases liver energy status in advanced lung cancer patients: an in vivo 31P magnetic resonance spectroscopy study. Hepatology 2002; 35: 421-424.

14 Adam J.K., Odhav B. and Bhoola K.D. Immune responses in cancer. Pharmacol Ther 2003; 99: 113-132.

15 Curfs J.H., Meis J.F. and Hoogkamp-Korstanje J.A. A primer on cytokines: sources, receptors, effects, and inducers. Clin Microbiol Rev 1997; 10: 742-780.

16 Sutmuller R.P., Offringa R. and Melief C.J. Revival of the regulatory T cell: new targets for drug development. Drug Discov Today 2004; 9: 310-316.

17 Roncarolo M.G., Bacchetta R., Bordignon C., Narula S. and Levings M.K. Type 1 T regulatory cells. Immunol Rev 2001; 182: 68-79. 
18 Yaqoob P., Newsholme E.A. and Calder P.C. Comparison of cytokine production in cultures of whole human blood and purified mononuclear cells. Cytokine 1999; 11: 600-605.

19 De Groote D., Zangerle P.F., Gevaert Y., Fassotte M.F., Beguin Y., Noizat-Pirenne F., Pirenne J., Gathy R., Lopez M., Dehart I. and et al. Direct stimulation of cytokines (IL-1 beta, TNFalpha, IL-6, IL-2, IFN-gamma and GM-CSF) in whole blood. I. Comparison with isolated PBMC stimulation. Cytokine 1992; 4: 239-248.

20 Ferrari D., Wesselborg S., Bauer M.K. and Schulze-Osthoff K. Extracellular ATP activates transcription factor NF-kappaB through the P2Z purinoreceptor by selectively targeting NFkappaB p65. J Cell Biol 1997; 139: 1635-1643.

21 Sperlagh B., Hasko G., Nemeth Z. and Vizi E.S. ATP released by LPS increases nitric oxide production in raw 264.7 macrophage cell line via P2Z/P2X7 receptors. Neurochem Int 1998; 33: 209-215.

22 Di Virgilio F. The P2Z purinoceptor: an intriguing role in immunity, inflammation and cell death. Immunol Today 1995; 16: 524-528.

23 Ralevic V. and Burnstock G. Receptors for purines and pyrimidines. Pharmacol Rev 1998; 50 : 413-492.

24 Ogata T., Chuai M., Morino T., Yamamoto H., Nakamura Y. and Schubert P. Adenosine triphosphate inhibits cytokine release from lipopolysaccharide-activated microglia via $P(2) y$ receptors. Brain Res 2003; 981: 174-183.

25 Duhant X., Schandene L., Bruyns C., Gonzalez N.S., Goldman M., Boeynaems J.M. and Communi D. Extracellular adenine nucleotides inhibit the activation of human CD4+ T lymphocytes. J Immunol 2002; 169: 15-21.

26 Takeda K., Kaisho T. and Akira S. Toll-like receptors. Annu Rev Immunol 2003; 21: 335-376.

27 Muzio M., Natoli G., Saccani S., Levrero M. and Mantovani A. The human toll signaling pathway: divergence of nuclear factor kappaB and JNK/SAPK activation upstream of tumour necrosis factor receptor-associated factor 6 (TRAF6). J Exp Med 1998; 187: 2097-2101.

28 Schletter J., Heine H., Ulmer A.J. and Rietschel E.T. Molecular mechanisms of endotoxin activity. Arch Microbiol 1995; 164: 383-389.

29 Sullivan G.W. and J I. Role of A2a adenosine receptors in inflammation. drug development research 1998; 45: 103-112.

30 Zidek Z. Adenosine - cyclic AMP pathways and cytokine expression. Eur Cytokine Netw 1999; 10: 319-328. 


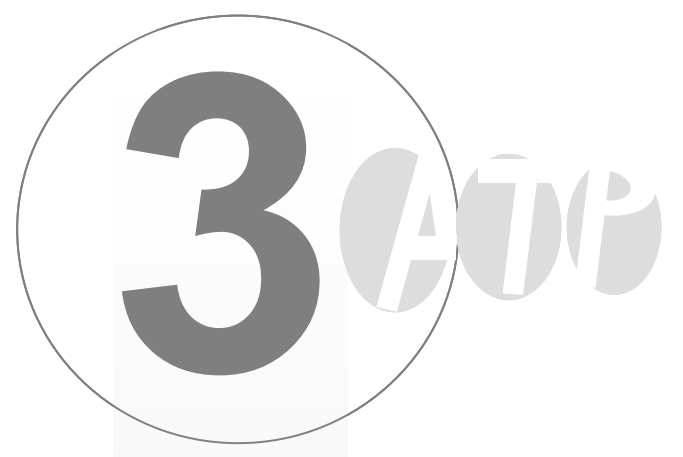

ATP inhibits hydroxyl radical formation and the inflammatory response of stimulated whole blood even under circumstances of severe oxidative stress

\section{Els L.R. Swennen Pieter C. Dagnelie Aalt Bast}

Free Radical Research 2006; 40: 53-58 


\begin{abstract}
We recently reported that adenosine 5'-triphosphate (ATP) is able to inhibit the inflammatory reaction in stimulated whole blood. Many diseases, in which inflammatory reactions are involved, are associated with oxidative stress. In the present study, we therefore investigated the effect of ATP on cytokine release in stimulated whole blood under conditions of oxidative stress, as simulated by preincubation of blood with hydrogen peroxide $\left(\mathrm{H}_{2} \mathrm{O}_{2}\right)$. In the presence of $\mathrm{H}_{2} \mathrm{O}_{2}$, ATP at concentrations of 100 and $300 \mu \mathrm{M}$ inhibited tumour necrosis factor-alpha (TNF- $\alpha$ ) release and stimulated interleukin (IL)-10 release in lipopolysaccharide (LPS)phytohemagglutinin (PHA) stimulated whole blood. Moreover, electron spin resonance (ESR) measurements showed that ATP and its breakdown product adenosine 5'-diphosphate (ADP) attenuated spin trap-hydroxyl radical $\left(\mathrm{OH}^{\circ}\right)$ adduct formation in the Fenton reaction. Our results demonstrate that even in circumstances of severe oxidative stress, ATP has marked anti-inflammatory properties in stimulated whole blood. Moreover, the inhibition of the $\mathrm{OH}^{\circ}$-ESR signal indicates a direct attenuation of oxidative stress by ATP.
\end{abstract}




\section{Introduction}

There is evidence that oxidative stress, defined as an unbalance between increased exposure to oxidants and decreased antioxidant capacities, plays an important role in the pathogenesis and progression of chronic diseases such as chronic obstructive pulmonary disease (COPD) [1-4], cancer [5, 6], neurological diseases [7, 8] such as Parkinson, Alzheimer and amyotrophic lateral sclerosis, and in cardiovascular diseases [9]. Also radiotherapy, a commonly used therapy for cancer, is well known to cause DNA damage through the production of reactive oxygen species (ROS); this intense formation of ROS is thought to cause a relative overshoot in ROS, which overwhelms the enzymatic and non-enzymatic antioxidant protection [10]. Oxidative stress, and so an increased level of ROS, has been considered as a central event in the mediation of inflammatory responses through the activation of transcriptions factors such as nuclear factor kappaB (NFkB) and activator protein-1 (AP-1), which trigger the expression of pro-inflammatory mediators [11, 12].

Extracellular adenosine 5'-triphosphate (ATP) is an important modulator of immune cell function [13-17]. ATP can be released from the cytoplasm of several cell types and interacts with specific purinergic (P1 and P2) receptors, which are present on the surface of many cells. In contrast with the general notion that ATP has predominantly pro-inflammatory effects in isolated cell systems in vitro [13,14, 18], we recently demonstrated that ATP inhibits the inflammatory response in stimulated whole blood, as indicated by inhibition of the release of the pro-inflammatory cytokine, tumour necrosis factor-alpha (TNF- $\alpha$ ) and stimulation of the antiinflammatory cytokine, interleukin (IL)-10 [19]. During incubation with hydrogen peroxide $\left(\mathrm{H}_{2} \mathrm{O}_{2}\right)$, hydroxyl radicals $\left(\mathrm{OH}^{*}\right)$ are formed. Since $\mathrm{OH}^{*}$ stimulate the inflammatory response through activation of transcription factors, this could influence the previously observed anti-inflammatory properties of ATP. At the same time, oxidative stress can affect the binding of ligands to membrane receptors, such as beta-adrenergic receptors and muscarinic receptors, as well as the coupling of receptors to G-proteins or the effect of second messengers [20]. Based on these findings, the receptor-mediated anti-inflammatory properties of ATP might well be altered under conditions of induced oxidative stress.

The aim of the present study was to determine the effect of ATP on cytokine release in whole blood under circumstances of oxidative stress. For this purpose, we utilized a model of whole blood stimulated with lipopolysaccharide (LPS) and phytohemagglutinin (PHA), as published earlier [19], in combination with $\mathrm{H}_{2} \mathrm{O}_{2}$ preincubation in order to induce oxidative stress. Appropriate control experiments suggested a scavenging effect of ATP on $\mathrm{OH}^{\circ}$, which was further investigated by electron spin resonance (ESR) measurements. 


\section{Materials and methods}

\section{Chemicals}

Purified PHA HA16 was from Murex, Dartford, UK. Human TNF- $\alpha$ (7300 pg/ml), human IL-10 (4000 pg/ml) and human IL-6 (4500 pg/ml) were obtained from CLB/Sanquin, The Netherlands. RPMI 1640 medium containing L-glutamine was obtained from Gibco, UK. ATP was purchased from Calbiochem, USA. $\mathrm{H}_{2} \mathrm{O}_{2}$ was obtained from Merck. All other chemicals were from Sigma Chemical Company (St. Louis).

\section{Incubation conditions}

Blood was collected from eight healthy volunteers (age range: 25-45 years; five women and three men) in heparin containing vacutainer tubes (Vacutainer, BectonDickinson, 170 I.U). In all the experiments, blood was stored on ice and the incubations were started within one hour after blood collection [19]. Whole blood was aliquoted into 24-well sterile plates and diluted 1:4 with RPMI 1640 (supplemented with L-glutamine). To induce cytokine production, PHA and bacterial LPS were added to whole blood at $1 \mu \mathrm{g} / \mathrm{ml}$ and $10 \mu \mathrm{g} / \mathrm{ml}$ respectively. After addition of $\mathrm{H}_{2} \mathrm{O}_{2}$, ATP and the stimulants LPS and PHA, the plates were incubated in $5 \%$ $\mathrm{CO}_{2}$ at $37^{\circ} \mathrm{C}$ for $24 \mathrm{~h}$. Cell-free supernatant fluids were then collected by centrifugation $\left(6000 \mathrm{rpm}, 10 \mathrm{~min}\right.$ at $4^{\circ} \mathrm{C}$ ) and stored at $-20^{\circ} \mathrm{C}$ until tested for presence of cytokines. All incubations were performed in triplicate.

$\mathrm{H}_{2} \mathrm{O}_{2}$ and ATP were dissolved in RPMI 1640 culture medium. $\mathrm{H}_{2} \mathrm{O}_{2}$ was added to the blood in a final concentration of 1,5 and $10 \mathrm{mM}$ in the first 15 min incubation step. After this pre-incubation, ATP was added to the blood in a final concentration range of $1-300 \mu \mathrm{M}$ in the 30 min incubation step. Blood was pre-incubated with $\mathrm{H}_{2} \mathrm{O}_{2}$ at $5 \% \mathrm{CO}_{2}$ and $37^{\circ} \mathrm{C}$ for $15 \mathrm{~min}$ before incubation with ATP. The blood was incubated for 30 min with ATP prior to stimulation with LPS + PHA for $24 \mathrm{~h}$ also at $5 \% \mathrm{CO}_{2}$ and $37^{\circ} \mathrm{C}$.

\section{Enzyme linked immune sorbent assay (ELISA)}

All cytokines were quantified by means of PeliKine Compact human ELISA kits (CLB/Sanquin, The Netherlands), based on appropriate and validated sets of monoclonal antibodies. Assays were performed as described by the manufacturer's instructions. Monoclonal antibodies specific for each component were pre-coated overnight at room temperature in 96-well polystyrene microtiter plates. Standards and samples were added into the wells and then incubated for $1 \mathrm{~h}$ at room temperature. The antibody on the microtiter plate then captured the cytokine present in a measured volume of sample or standard and non-bound material was removed 
by washing. Subsequently, a biotinylated second monoclonal antibody for each of the components was added and incubated for $1 \mathrm{~h}$ at room temperature. Following a washing to remove unbound antibody-enzyme reagents, horseradish peroxidase (HRP)-conjugated streptavidin, which binds onto the biotinylated side of the cytokine complex, was added to the wells and incubated for $30 \mathrm{~min}$ at room temperature. After removal of the non-bound HRP conjugate by washing, a substrate solution was added to the wells and incubated for $30 \mathrm{~min}$ at room temperature. Color development was stopped by addition of sulfuric acid and the intensity of the color was measured by a microtiter plate reader (absorbance at $450 \mathrm{~nm}$ ). The absorbance was transformed to cytokine concentrations $(\mathrm{pg} / \mathrm{ml})$ using the standard curve.

\section{Electron spin resonance (ESR) spectroscopy}

ESR studies were performed at room temperature using a Bruker EMX 1273 spectrometer equipped with an ER 4119HS high sensitivity cavity and $12 \mathrm{~kW}$ power supply. The following instrument conditions were used: scan range, $60 \mathrm{G}$; center magnetic field, $3490 \mathrm{G}$; modulation amplitude, $1.0 \mathrm{G}$; microwave frequency, 9.86 $\mathrm{GHz}$; time constant, $40.96 \mathrm{~ms}$, scan time, $20.48 \mathrm{~ms}$ and number of scans, $50 . \mathrm{OH}^{\circ}$ were generated by the Fenton reaction, and 5,5-dimethyl-1-pyrroline-N-oxide (DMPO) was used for trapping $\mathrm{OH}^{\circ}$. Fifty microliters of $10 \mathrm{mM} \mathrm{H}_{2} \mathrm{O}_{2}, 50 \mu \mathrm{l}$ of 250 $\mathrm{mM}$ DMPO, $50 \mu \mathrm{l}$ milliQ (control) or sample, and $50 \mu \mathrm{l}$ of $5 \mathrm{mM} \mathrm{FeSO}_{4} / 5 \mathrm{mM}^{\mathrm{EDTA}}$ were mixed and transferred to a capillary glass tube. DMPO-OH spin adducts were measured after 2 minutes by ESR. Quantification of the spectra (in arbitrary units) was performed by peak integration using the WIN-EPR spectrum manipulation program.

\section{Statistical analyses}

The effect of $\mathrm{H}_{2} \mathrm{O}_{2}$ on the cytokine release in the absence/presence of ATP was compared to the control (no $\mathrm{H}_{2} \mathrm{O}_{2}$ /no ATP) using Wilcoxon's signed rank test. Differences between ESR signal peak areas were analyzed by Student t-test. Twotailed P-values of 0.05 or less were considered statistically significant. Results are reported as means \pm SEM.

\section{Results}

Figure 1 shows the effect of ATP on the TNF- $\alpha$ release in LPS-PHA-stimulated whole blood in the absence and presence of different concentrations of $\mathrm{H}_{2} \mathrm{O}_{2}$. ATP, in the absence of $\mathrm{H}_{2} \mathrm{O}_{2}$, concentration dependently and significantly inhibited TNF- $\alpha$ release from LPS-PHA-stimulated whole blood at $100 \mu \mathrm{M}$ and $300 \mu \mathrm{M}$ by $32 \pm 9 \%$ 
(mean \pm SEM) and $65 \pm 5 \%$, respectively. Lower concentrations of ATP $(1,3,10$ and $30 \mu \mathrm{M}$ ), did not affect TNF- $\alpha$ release (data not shown).

As seen in figure 1, ATP, in the presence of $1 \mathrm{mM} \mathrm{H}_{2} \mathrm{O}_{2}$, also significantly inhibited TNF- $\alpha$ release from LPS-PHA-stimulated whole blood by $24 \pm 9 \%$ at an ATP concentration of $100 \mu \mathrm{M}$ and by $52 \pm 6 \%$ at a concentration of $300 \mu \mathrm{M}$ ATP. In the presence of 5 and $10 \mathrm{mM} \mathrm{H}_{2} \mathrm{O}_{2}$, the inhibition of TNF- $\alpha$ release by $100 \mu \mathrm{M}$ of ATP was no longer significant, but $300 \mu \mathrm{M}$ of ATP still significantly inhibited TNF- $\alpha$ release by $46 \pm 5 \%$ and $53 \pm 8 \%$, respectively. ATP concentrations below $100 \mu \mathrm{M}$, when combined with the three different concentrations of $\mathrm{H}_{2} \mathrm{O}_{2}$, did not affect TNF- $\alpha$ release (data not shown).

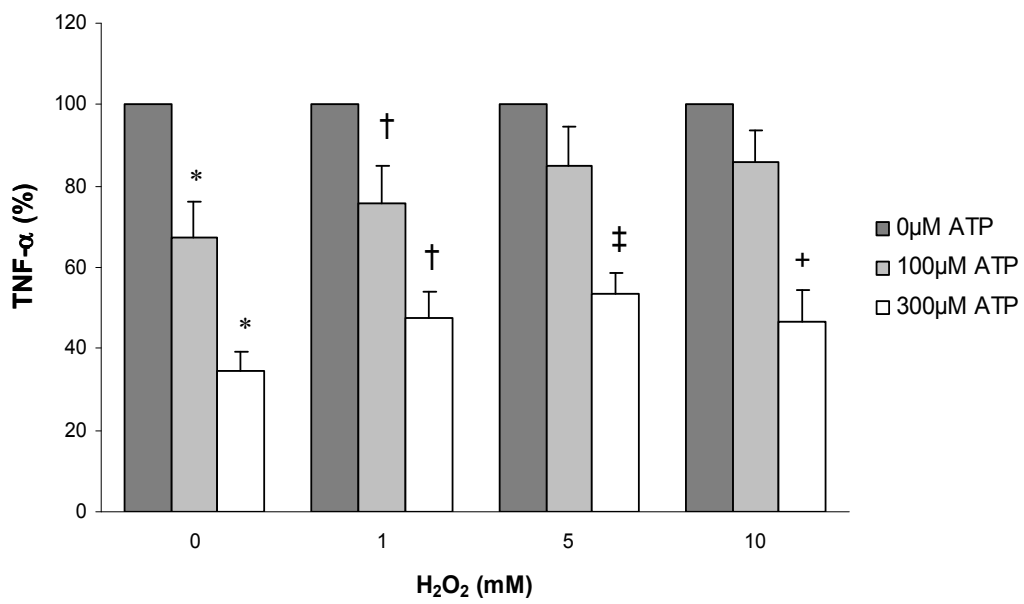

Figure 1: Effect of ATP on LPS-PHA-induced TNF- $\alpha$ secretion in whole blood from healthy subjects in the presence of different concentrations of $\mathrm{H}_{2} \mathrm{O}_{2}$. Whole blood was pre-incubated for $15 \mathrm{~min}$ with $\mathrm{H}_{2} \mathrm{O}_{2}$, followed by incubation with ATP for $30 \mathrm{~min}$ and stimulation with LPS and PHA for $24 \mathrm{~h}$. Results are expressed as percentage, $100 \%$ being the TNF- $\alpha$ release under stimulation by LPSPHA without ATP in the presence of the same concentration $(0,1,5$ and $10 \mathrm{mM}) \mathrm{H}_{2} \mathrm{O}_{2}$ (=control). Data are mean \pm SEM in eight subjects. ${ }^{*} \mathrm{P}<0.05$ when compared to control $(100 \%=$ no ATP and no $\left.\mathrm{H}_{2} \mathrm{O}_{2}\right)$. ${ }^{\dagger} \mathrm{P}<0.05$ when compared to control $\left(100 \%=\right.$ no ATP and $\left.1 \mathrm{mM} \mathrm{H}_{2} \mathrm{O}_{2}\right) .{ }^{\ddagger} \mathrm{P}<0.05$ when compared to control $\left(100 \%=\right.$ no ATP and $\left.5 \mathrm{mM} \mathrm{H}_{2} \mathrm{O}_{2}\right) .{ }^{+} \mathrm{P}<0.05$ when compared to control $(100 \%$ $=$ no ATP and $10 \mathrm{mM} \mathrm{H}_{2} \mathrm{O}_{2}$ ).

ATP, in the absence of $\mathrm{H}_{2} \mathrm{O}_{2}$, significantly increased IL-10 release from stimulated whole blood at 100 and $300 \mu \mathrm{M}$ by $93 \pm 56 \%$ and $166 \pm 71 \%$, respectively (Figure 2). Also after pre-incubation with 1 and $5 \mathrm{mM} \mathrm{H}_{2} \mathrm{O}_{2}$, ATP significantly increased IL10 release: at $100 \mu \mathrm{M}$ ATP, the increase in IL-10 relative to the control condition $\left(\mathrm{H}_{2} \mathrm{O}_{2}\right.$ but no ATP) amounted to $34 \pm 15 \%$ and $80 \pm 11 \%$ at 1 and $5 \mathrm{mM} \mathrm{H}_{2} \mathrm{O}_{2}$, respectively, and at $300 \mu \mathrm{M}$ ATP to $114 \pm 29 \%$ and $79 \pm 24 \%$, respectively. 
Again, at $10 \mathrm{mM} \mathrm{H} \mathrm{O}_{2}$, only the highest concentration of ATP had a significant stimulatory effect on IL-10 release of $315 \pm 102 \%$. After $5 \mathrm{mM} \mathrm{H}_{2} \mathrm{O}_{2}$ pre-incubation, no difference between the effect of 100 and $300 \mu \mathrm{M}$ ATP was observed. ATP concentrations below $100 \mu \mathrm{M}$ had no effect on IL-10 release, regardless of whether $\mathrm{H}_{2} \mathrm{O}_{2}$ was absent or present (data not shown).

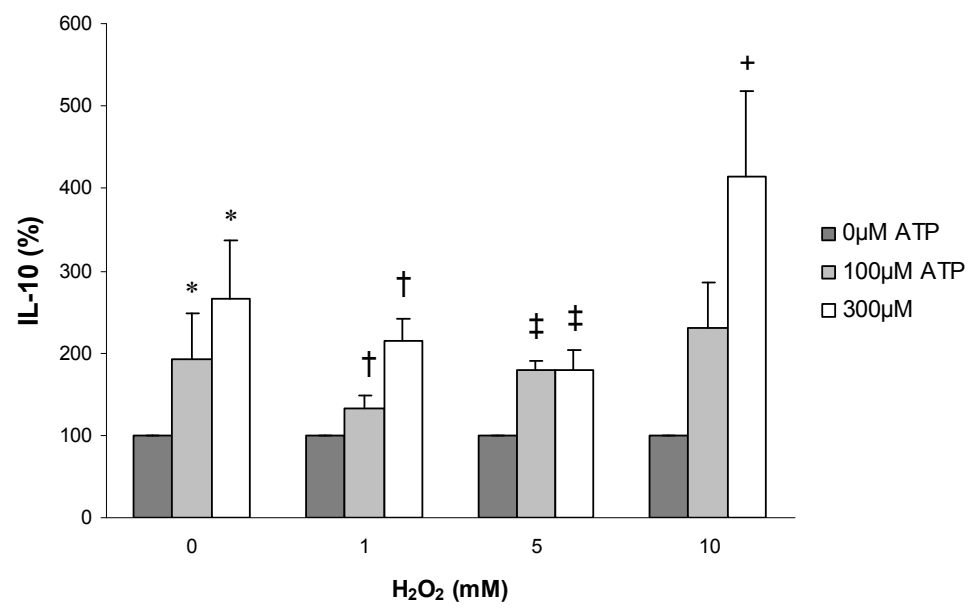

Figure 2: The effect of ATP on LPS-PHA-induced IL-10 secretion in whole blood from healthy subjects in the presence of different concentrations of $\mathrm{H}_{2} \mathrm{O}_{2}$. Whole blood was pre-incubated for 15 min with $\mathrm{H}_{2} \mathrm{O}_{2}$, followed by incubation with ATP for 30 min and stimulation with LPS and PHA for 24 h. Results are expressed as percentage, $100 \%$ being the IL-10 release under stimulation by LPSPHA without ATP in the presence of the same concentration $(0,1,5$ and $10 \mathrm{mM}) \mathrm{H}_{2} \mathrm{O}_{2}$ (=control). Data are mean \pm SEM in eight subjects. ${ }^{*} \mathrm{P}<0.05$ when compared to control $(100 \%=$ no ATP and no $\left.\mathrm{H}_{2} \mathrm{O}_{2}\right)$. ${ }^{\dagger} \mathrm{P}<0.05$ when compared to control $\left(100 \%=\right.$ no ATP and $\left.1 \mathrm{mM} \mathrm{H}_{2} \mathrm{O}_{2}\right) .{ }^{\ddagger} \mathrm{P}<0.05$ when compared to control $\left(100 \%=\right.$ no ATP and $\left.5 \mathrm{mM} \mathrm{H}_{2} \mathrm{O}_{2}\right)$. ${ }^{+} \mathrm{P}<0.05$ when compared to control $(100 \%=$ no ATP and $10 \mathrm{mM} \mathrm{H}_{2} \mathrm{O}_{2}$ ).

ATP had no effect on IL-6 release from LPS-PHA-stimulated whole blood either in the absence or presence of $1 ; 5$ and $10 \mathrm{mM} \mathrm{H}_{2} \mathrm{O}_{2}$ (data not shown).

$\mathrm{H}_{2} \mathrm{O}_{2}$, added to whole blood in the absence of both ATP and LPS-PHA, seemed to induce a dose-dependent stimulation of TNF- $\alpha$, IL-10 and IL- 6 release, which did however not reach statistical significance when compared with the control condition (no $\mathrm{H}_{2} \mathrm{O}_{2}$ ) (data not shown). In the presence of LPS and PHA, $10 \mathrm{mM} \mathrm{H}_{2} \mathrm{O}_{2}$ showed a significant inhibition on LPS-PHA-induced TNF- $\alpha$ release (decrease from 6487 $\mathrm{pg} / \mathrm{ml} \pm 2469$ to $4091 \mathrm{pg} / \mathrm{ml} \pm 2206, \mathrm{P}<0.05$ ), while IL-10 and IL-6 release were not influenced (data not shown). 
To investigate the direct effects of ATP on $\mathrm{OH}^{\bullet}$ formation, we tested the scavenging effects of ATP on $\mathrm{OH}^{\bullet}$ by means of ESR measurements. As shown in figure 3, even ATP concentrations as low as $100 \mu \mathrm{M}$ showed an inhibiting effect on DMPO-OH spin adduct formation generated by the Fenton reaction. Moreover, a concentration dependent inhibition of DMPO-OH spin adduct formation was observed by incubating with either adenosine 5'-diphosphate (ADP) or ATP. ATP was slightly more effective than ADP in preventing DMPO-OH formation.

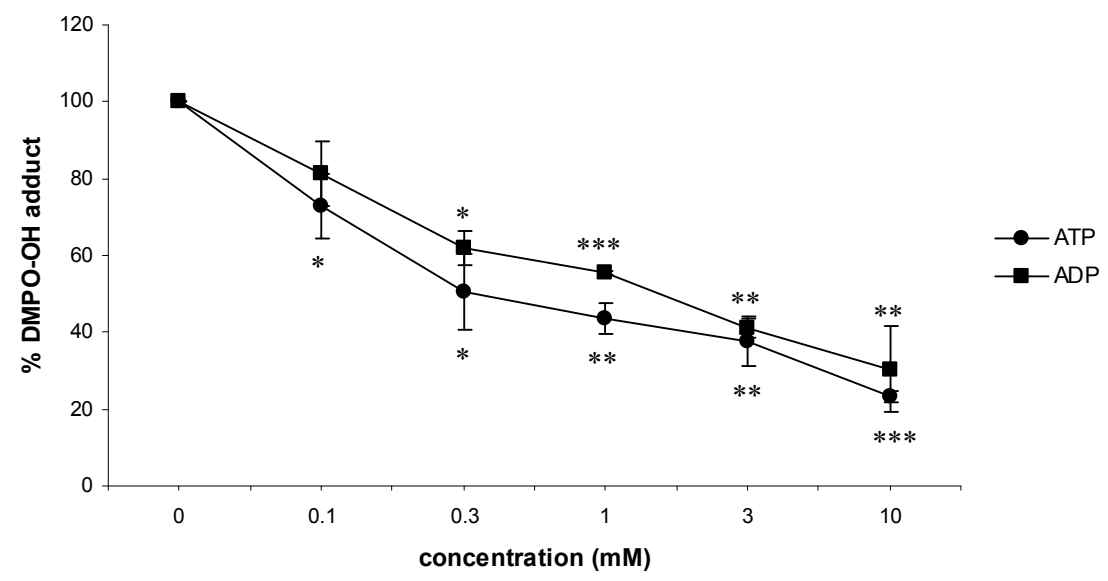

Figure 3: Inhibition by ATP and ADP of DMPO-OH spin adduct formation. After addition of ATP or ADP, DMPO-OH spin adducts were analyzed using ESR spectrometry. Values were means of triplicate determinations, and $100 \%$ is the percentage of DMPO-OH spin adducts formed when no ATP or ADP is present (control). Statistically significant deviations relative to control are represented by ${ }^{*} \mathrm{P}<0.05,{ }^{* *} \mathrm{P}<0.01$ and ${ }^{* * *} \mathrm{P}<0.001$.

The DMPO-OH spectrum generated by the Fenton reaction after addition of milliQ (control, spectrum A) or ATP (spectrum B) is shown in figure 4.
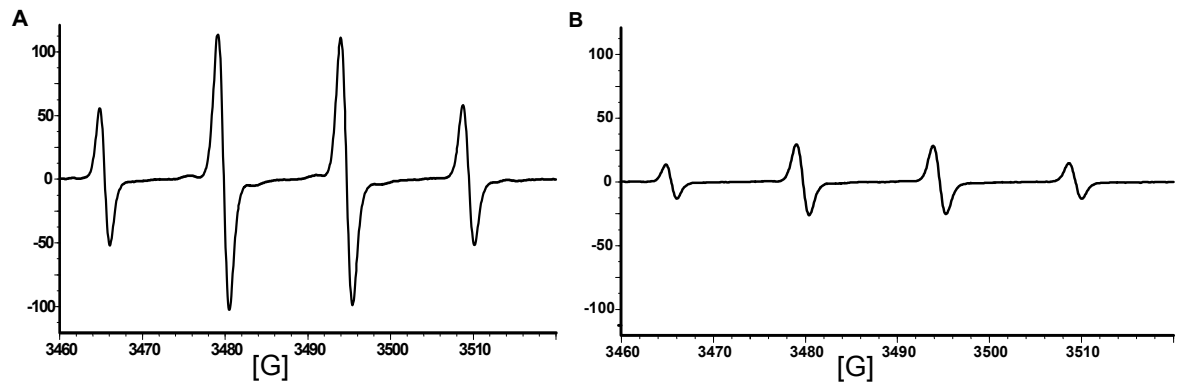

Figure 4: DMPO-OH signal of control (A) and ATP (B). After addition of milliQ (control) or ATP, DMPO-OH spin adducts were analyzed using ESR spectrometry. 
Adenosine (5 mM) showed no effect on DMPO-OH spin adduct formation (data not shown). Adenosine 5'-monophosphate (AMP) showed a reduction of DMPO-OH spin adduct formation at 3 and $10 \mathrm{mM}$, but at lower concentrations $(0.1 \mathrm{mM}, 0.3 \mathrm{mM}$ and $1 \mathrm{mM}$ ) there was no effect (data not shown).

\section{Discussion}

We recently [19] reported that ATP resulted in an inhibition of TNF- $\alpha$ and stimulation of IL-10 release in LPS-PHA-stimulated whole blood. In the present study, we investigated the anti-inflammatory effects of ATP under different conditions of oxidative stress in stimulated whole blood, a type of experiment not previously performed. We selected the compound ATP because we previously reported that on the one hand, ATP showed a stronger anti-inflammatory effect in stimulated whole blood in comparison with its breakdown product ADP and on the other hand, this effect seemed to be P2 receptor mediated and did not involve the breakdown product adenosine [19]. The rationale underlying the present study was the notion that many inflammatory diseases are characterized by an oxidant/antioxidant imbalance, leading to oxidative stress [4, 10, 21]. It is well known that oxidative stress affects both receptor function and signal transmission systems. Thus, Van der Vliet et al. [20] reported that oxidative stress can affect receptor function by influencing the binding of ligands to membrane receptors or the signal transduction system, i.e. coupling of these receptors to G-proteins or affecting the second messenger activity. These effects of oxidative stress could be caused either by peroxidation of membrane lipids, or by interaction of ROS with functional thiol/disulfide groups in the receptor. We therefore hypothesized that oxidative stress could compromise the previously demonstrated anti-inflammatory properties of ATP under circumstances of oxidative stress. Remarkably, results show that ATP strongly inhibited cytokine release even under circumstances of severe oxidative stress, induced by $\mathrm{H}_{2} \mathrm{O}_{2}$ at levels as high as $10 \mathrm{mM}$. These high $\mathrm{H}_{2} \mathrm{O}_{2}$ concentrations are not directly linked to the in vivo situation, but our goal was to investigate a state of extreme oxidative stress. Moreover, it should be noted that catalase, which brakes down most of the $\mathrm{H}_{2} \mathrm{O}_{2}$, is present in blood and therefore, the final $\mathrm{H}_{2} \mathrm{O}_{2}$ concentration in blood will be lower.

The effect of $\mathrm{H}_{2} \mathrm{O}_{2}$ as an oxidative stress factor on cytokine production has been studied in isolated cells in vitro. Indeed, previous studies have shown that $\mathrm{H}_{2} \mathrm{O}_{2}$ can induce cytokine production in various cell types, such as macrophages [22], cardiomyocytes [23] and keratinocytes [24]. Furthermore, several potential mechanisms underlying $\mathrm{H}_{2} \mathrm{O}_{2}$-induced cytokine production have been proposed, including NF $\kappa B$ activation $[25,26]$. We showed that in the absence of LPS and PHA, $\mathrm{H}_{2} \mathrm{O}_{2}$ induced a dose-dependent increase in the release of TNF- $\alpha$, IL-10 and IL- 6 in whole blood in six out of eight subjects, indicating that the addition of $\mathrm{H}_{2} \mathrm{O}_{2}$ in this 
whole blood system induces oxidative stress and thereby activates pro-inflammatory genes. Due to the high inter-individual variation, possibly by a different genetic background of different subjects, the average effect was however not significantly different from the control.

$\mathrm{H}_{2} \mathrm{O}_{2}$, in the absence of ATP, did not alter the LPS-PHA-induced IL-10 or IL-6 production from whole blood relative to LPS-PHA stimulation without $\mathrm{H}_{2} \mathrm{O}_{2}$. In contrary, at the highest concentration of $10 \mathrm{mM} \mathrm{H}_{2} \mathrm{O}_{2}$, there was a significant attenuation of LPS-PHA-induced TNF- $\alpha$ release. This effect could be caused by interference of $\mathrm{H}_{2} \mathrm{O}_{2}$ with the LPS mechanism, which is responsible for the TNF- $\alpha$ production by $\mathrm{NF} \kappa \mathrm{B}$ activation [27, 28]. One intriguing explanation for the attenuation of the LPS-PHA-induced TNF- $\alpha$ release in the presence of the highest concentration of $\mathrm{H}_{2} \mathrm{O}_{2}$, could be that $\mathrm{H}_{2} \mathrm{O}_{2}$ affects the physical approximation of tolllike receptor 4 (TLR4) with CD14 receptors, an event which is involved in the LPSinduced NFKB activation with subsequent cytokine release [29].

The marked anti-inflammatory effect of ATP, even during severe oxidative stress, might be explained by the possibility that ATP, or some of its breakdown products, may interfere with processes which are directly induced by $\mathrm{H}_{2} \mathrm{O}_{2}$, e.g. possible protection by ATP against oxidative stress-induced damage at the receptor level, or by influencing $\mathrm{OH}^{\bullet}$ formation from $\mathrm{H}_{2} \mathrm{O}_{2}$. We tested whether ATP is able to inhibit the formation of $\mathrm{OH}^{\circ}$, as a potential contribution to its marked effects on cytokine production in the presence of $\mathrm{H}_{2} \mathrm{O}_{2}$. Results demonstrate that ATP and ADP, even at a concentration of $100 \mu \mathrm{M}$, showed a concentration dependent inhibition of the formation of DMPO-OH spin adducts. This implies that ATP, besides its antiinflammatory effects, also has a radical scavenging effect that might contribute to the cytoprotective and anti-inflammatory effects of ATP in the presence of oxidative stress.

In conclusion, we have shown that ATP exerts strong anti-inflammatory actions in stimulated whole blood under conditions of marked $\mathrm{H}_{2} \mathrm{O}_{2}$-induced oxidative stress. This suggests that the inhibitory effect of ATP on inflammation is relatively insensitive to oxidative stress. In addition, our findings in ESR experiments that ATP strongly inhibits $\mathrm{OH}^{*}$ formation, suggests that ATP, in addition to its antiinflammatory effects, also attenuates oxidative stress itself. Thus, our results indicate that ATP is able to function as a strong combined oxidative stress-inhibiting and anti-inflammatory agent. 


\section{References}

1 Boots A.W., Haenen G.R. and Bast A. Oxidant metabolism in chronic obstructive pulmonary disease. Eur Respir J Suppl 2003; 46: 14s-27s.

2 Repine J.E., Bast A. and Lankhorst I. Oxidative stress in chronic obstructive pulmonary disease. Oxidative Stress Study Group. Am J Respir Crit Care Med 1997; 156: 341-357.

3 Morcillo E.J., Estrela J. and Cortijo J. Oxidative stress and pulmonary inflammation: pharmacological intervention with antioxidants. Pharmacol Res 1999; 40: 393-404.

4 MacNee W. Oxidative stress and lung inflammation in airways disease. Eur J Pharmacol 2001; 429: 195-207.

5 Mantovani G., Maccio A., Madeddu C., Mura L., Gramignano G., Lusso M.R., Massa E., Mocci $M$. and Serpe R. Antioxidant agents are effective in inducing lymphocyte progression through cell cycle in advanced cancer patients: assessment of the most important laboratory indexes of cachexia and oxidative stress. J Mol Med 2003.

6 Gackowski D., Banaszkiewicz Z., Rozalski R., Jawien A. and Olinski R. Persistent oxidative stress in colorectal carcinoma patients. Int J Cancer 2002; 101: 395-397.

7 Gilgun-Sherki Y., Melamed E. and Offen D. Oxidative stress induced-neurodegenerative diseases: the need for antioxidants that penetrate the blood brain barrier. Neuropharmacology 2001; 40: 959-975.

8 Agar J. and Durham H. Relevance of oxidative injury in the pathogenesis of motor neuron diseases. Amyotroph Lateral Scler Other Motor Neuron Disord 2003; 4: 232-242.

9 Molavi B. and Mehta J.L. Oxidative stress in cardiovascular disease: molecular basis of its deleterious effects, its detection, and therapeutic considerations. Curr Opin Cardiol 2004; 19: 488-493.

10 Bast A., Haenen G.R. and Doelman C.J. Oxidants and antioxidants: state of the art. Am J Med 1991; 91: 2S-13S.

11 Rahman I. and MacNee W. Role of transcription factors in inflammatory lung diseases. Thorax 1998; 53: 601-612.

12 Rahman I. and MacNee W. Oxidative stress and regulation of glutathione in lung inflammation. Eur Respir J 2000; 16: 534-554.

13 Grahames C.B., Michel A.D., Chessell I.P. and Humphrey P.P. Pharmacological characterization of ATP- and LPS-induced IL-1beta release in human monocytes. $\mathrm{Br} \mathrm{J}$ Pharmacol 1999; 127: 1915-1921.

14 Sanz J.M. and Di Virgilio F. Kinetics and mechanism of ATP-dependent IL-1 beta release from microglial cells. J Immunol 2000; 164: 4893-4898.

15 Perregaux D.G., McNiff P., Laliberte R., Conklyn M. and Gabel C.A. ATP acts as an agonist to promote stimulus-induced secretion of IL-1 beta and IL-18 in human blood. J Immunol 2000; 165: 4615-4623.

16 Hide I., Tanaka M., Inoue A., Nakajima K., Kohsaka S., Inoue K. and Nakata Y. Extracellular ATP triggers tumour necrosis factor-alpha release from rat microglia. J Neurochem 2000; 75: 965-972.

17 Shigemoto-Mogami Y., Koizumi S., Tsuda M., Ohsawa K., Kohsaka S. and Inoue K. Mechanisms underlying extracellular ATP-evoked interleukin-6 release in mouse microglial cell line, MG-5. J Neurochem 2001; 78: 1339-1349.

18 Ferrari D., Chiozzi P., Falzoni S., Hanau S. and Di Virgilio F. Purinergic modulation of interleukin-1 beta release from microglial cells stimulated with bacterial endotoxin. $J$ Exp Med 1997; 185: 579-582. 
19 Swennen E.L., Bast A. and Dagnelie P.C. Immunoregulatory effects of adenosine 5'triphosphate on cytokine release from stimulated whole blood. Eur J Immunol 2005; 35: 852858.

20 Van der Vliet A. and Bast A. Effect of oxidative stress on receptors and signal transmission. Chem Biol Interact 1992; 85: 95-116.

21 bast $\mathrm{A}$. antioxidant pharmacotherapy. DN\&P 1994; 7 (8).

22 Kaul N. and Forman H.J. Activation of NF kappa B by the respiratory burst of macrophages. Free Radic Biol Med 1996; 21: 401-405.

23 Chandrasekar B., Colston J.T., de la Rosa S.D., Rao P.P. and Freeman G.L. TNF-alpha and $\mathrm{H} 2 \mathrm{O} 2$ induce IL-18 and IL-18R beta expression in cardiomyocytes via NF-kappa B activation. Biochem Biophys Res Commun 2003; 303: 1152-1158.

24 Ikeda M., Hirose Y., Miyoshi K. and Kodama H. Nuclear factor kappaB (NF-kappaB) activation by hydrogen peroxide in human epidermal keratinocytes and the restorative effect of interleukin-10. J Dermatol Sci 2002; 28: 159-170.

25 Schoonbroodt S. and Piette J. Oxidative stress interference with the nuclear factor-kappa B activation pathways. Biochem Pharmacol 2000; 60: 1075-1083.

26 Bowie A. and O'Neill L.A. Oxidative stress and nuclear factor-kappaB activation: a reassessment of the evidence in the light of recent discoveries. Biochem Pharmacol 2000; 59: 13-23.

27 Bonizzi G. and Karin M. The two NF-kappaB activation pathways and their role in innate and adaptive immunity. Trends Immunol 2004; 25: 280-288.

28 Barnes P.J. and Karin M. Nuclear factor-kappaB: a pivotal transcription factor in chronic inflammatory diseases. N Engl J Med 1997; 336: 1066-1071.

29 Jiang Q., Akashi S., Miyake K. and Petty H.R. Lipopolysaccharide induces physical proximity between CD14 and toll-like receptor 4 (TLR4) prior to nuclear translocation of NF-kappa B. $J$ Immunol 2000; 165: 3541-3544. 


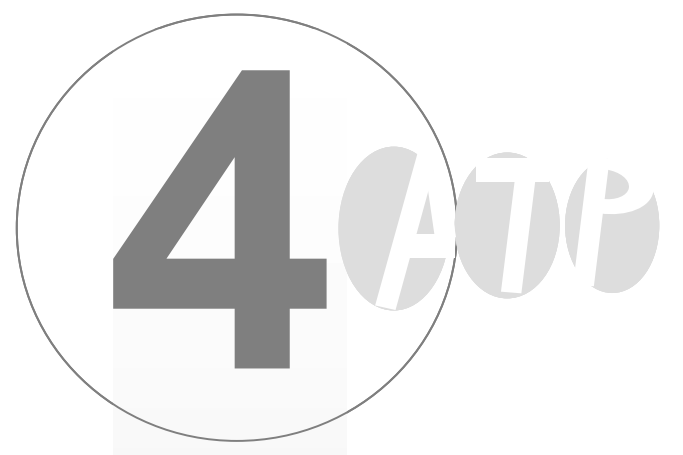

Purinergic receptors involved in the immunomodulatory effects of ATP in human blood

Els L.R. Swennen

Aalt Bast

Pieter C. Dagnelie

Biochemical and Biophysical Research Communications 2006; 348: 1194-1199 


\section{Abstract}

We recently showed that the physiological compound adenosine 5'-triphosphate (ATP) simultaneously inhibited tumour necrosis factor-alpha (TNF- $\alpha$ ) and stimulated interleukin (IL)-10 release in lipopolysaccharide (LPS)-phytohemagglutininstimulated blood. The purpose of the present study was to determine the mechanism involved in the concerted modulatory effect of ATP on TNF- $\alpha$ and IL-10. Incubation of blood with ATP in the presence of selective P2 receptor antagonists showed that the stimulatory effect of ATP on IL-10 release was completely annihilated by both 2-MeSAMP (a P2Y ${ }_{12 / 13}$ receptor antagonist) and PSB-0413 (a P2 $Y_{12}$ receptor antagonist). On the other hand, the inhibitory effect of ATP on TNF- $\alpha$ release was completely reversed by 5'-AMPS (a P2Y ${ }_{11}$ receptor antagonist) as well as by $\mathrm{H}-89$, an inhibitor of cyclic AMP (cAMP)-activated protein kinase A (PKA). The concerted inhibition by ATP of TNF- $\alpha$ release via $\mathrm{P}_{2} \mathrm{Y}_{11}$ activation and stimulation of IL-10 release via $\mathrm{P}_{2} \mathrm{Y}_{12}$ activation implicates a novel approach towards immunomodulation by altering the balance among pro- and anti-inflammatory cytokines. 


\section{Introduction}

So-called 'tumour necrosis factor-alpha (TNF- $\alpha$ ) blockers', such as infliximab $\left(\right.$ Remicade $\left.^{\circledR}\right)$, etanercept $\left(\right.$ Enbrel $^{\circledR}$ ) and adalimumab (Humira ${ }^{\circledR}$ ), are effective therapeutic agents for treating patients with severe rheumatologic and chronic inflammatory conditions [1, 2]. For instance, the well-studied clinical effects of these agents in rheumatoid arthritis (RA) include reduction of symptoms of joint inflammation, slowing the disease progression and arresting bone destruction [1, 2]. However, the use of these synthetic TNF- $\alpha$ blockers has also been associated with an increased rate of side effects such as tuberculosis, endemic mycoses and intracellular bacterial infections [3, 4]. Infliximab especially is associated with a markedly elevated risk of infection, due to its long half-life and induction of monocyte apoptosis [3, 4].

In view of the notion that both up-regulation of pro-inflammatory cytokines and down-regulation of anti-inflammatory cytokines contribute to chronic inflammatory conditions, a different approach in the treatment of such conditions could involve the combined modulation of both pro- and anti-inflammatory cytokines. We recently reported that the physiological compound adenosine 5'-triphosphate (ATP) modulates the immune response by simultaneously inhibiting TNF- $\alpha$ and stimulating interleukin (IL)-10 release in lipopolysaccharide (LPS)-phytohemagglutinin (PHA) stimulated whole blood from healthy subjects [5]. An important property of ATP, in comparison with TNF- $\alpha$ blockers, is that ATP appears to be able to modulate both the pro- and anti-inflammatory response in a concerted manner. Moreover, since ATP is a physiological compound, which is ubiquitously present in the human body, it is not surprising that clinical application of ATP in humans induces no long-term side effects. ATP is known to regulate a wide variety of physiological processes through the activation of purinergic $P 2$ receptors [6-8], which are subdivided into $\mathrm{P} 2 \mathrm{Y}$ and $\mathrm{P} 2 \mathrm{X}$ receptors $[7,9]$. Also adenosine, the breakdown product of ATP, is known to exhibit anti-inflammatory effects through the activation of $P 1$ receptors $[10$, 11].

The aim of the present study was to identify which receptors are involved in the recently reported immunomodulatory ATP effect on cytokine release. To identify which P2 receptors mediated the observed ATP effect, we tested the effect of ATP on cytokine release in stimulated blood in the presence of different P2 selective receptor antagonists. Since ATP is rapidly broken down to adenosine, we also tested the involvement of adenosine in the immunomodulatory effects of ATP by using $\mathrm{P} 1$ selective receptor antagonists. 


\section{Materials and methods}

\section{Reagents}

Purified PHA (HA16) was from Murex, Dartford, UK. Adenosine 5'-diphosphate (ADP), uridine 5'-triphosphate (UTP), ATP $\gamma \mathrm{S}$ (adenosine 5'-O-(3-thiotriphosphate)), 2-MeSATP, $\mathrm{P}^{1}, \quad \mathrm{P}^{4}$-di (adenosine-5') tretraphosphate $\left(\mathrm{Ap}_{4} \mathrm{~A}\right), \quad 2^{\prime}$-deoxy- $\mathrm{N}^{6}$ methyladenosine-3',5'-biphosphate (MRS2179), pyridoxalphosphate-6-azophenyl2',4'-disulfonic acid (PPADS), 2-MeSAMP, adenosine 5'-triphosphate 2',3'-acyclic dialcohol (oxidized ATP), adenosine 5'-O-thiomonophosphate (5'-AMPS), forskolin and LPS (E. Coli 0.26:B6) were purchased from Sigma Chemical Co, St. Louis, USA. Human TNF- $\alpha(7300 \mathrm{pg} / \mathrm{ml})$ and human IL-10 $(4000 \mathrm{pg} / \mathrm{ml})$ were obtained from CLB/Sanquin, The Netherlands. RPMI 1640 medium containing L-glutamine was obtained from Gibco, UK. ATP and $\mathrm{H}-89$ was purchased from Calbiochem, USA.

PSB-0413 (AR-C67085MX, 2-propylthioadenosine-5'-adenylic acid (1,1-dichloro-1phosphonomethyl-1-phosphonyl) anhydride) [12], PSB-63 (2-(hexahydro-2,5methanopentalen-3a-yl)-4,5-dihydro-9-propyl-6H,8H-pyrimido[1,2,3-cd]purine-

8,10(9H)-dione) [13], MSX-2 (3-(3-hydroxypropyl)-7-methyl-1-propargyl-8-(mmethoxystryryl)xanthine) $\quad[14, \quad 15], \quad$ PSB-10 (8-ethyl-4-methyl-2-(2,3,5trichlorophenyl)-(8R)-4,5,7,8-tetrahydro-1H-imidazo[2.1-i]purin-5-one) [16, 17] and PSB-1115 (1-propyl-8-p-sulfophenylxanthine $\times 2 \mathrm{H}_{2} \mathrm{O}$ ) $[18,19]$ were a kind gift from Prof. Dr. C.E. Müller (Pharmaceutical Chemistry University of Bonn).

\section{Blood assay and substance application}

The blood assay was performed as described previously [5]. To test receptor agonists, blood of healthy volunteers was incubated with medium (control) or agonists (P2 and P1 receptor agonists) for $30 \mathrm{~min}$ prior to stimulation with LPSPHA. The effects of various receptor antagonists were investigated by preincubating the blood for $15 \mathrm{~min}$ with the antagonists before the addition of medium (control) or ATP and the stimulants. Stock solutions of agonists and antagonists were prepared in external stock solution (dissolved either in RPMI 1640 culture medium, dimethyl sulfoxide (DMSO) or ethanol) stored at $-20^{\circ} \mathrm{C}$ and diluted immediately before use.

\section{Enzyme linked immune sorbent assay (ELISA) measurement}

All cytokines were quantified by means of PeliKine Compact human ELISA kits (CLB/Sanquin, The Netherlands), based on appropriate and validated sets of monoclonal antibodies as described previously [5]. 


\section{Statistics}

Statistical comparisons were made by Wilcoxon's signed rank test. Two-tailed Pvalues of 0.05 or less were considered statistically significant. Results are reported as means \pm SEM.

\section{Results}

\section{Purinergic receptors involved in the ATP-induced IL-10 stimulation}

To investigate whether P2 receptors modulate the $\mathrm{IL}-10$ response, we first determined the effects of purinergic receptor agonists on IL-10 release in blood. Similar to our earlier results [5], ATP strongly stimulated IL-10 release in blood (Figure 1). Of the tested $P 2 Y$ agonists, only ADP (P2Y $1 / P_{2} Y_{12}$ agonist) significantly stimulated IL-10 release (Figure 1). The other $\mathrm{P} 2 \mathrm{Y}$ receptor agonists such as ATP $\gamma \mathrm{S}$ (P2Y 11 agonist), 2-MeSATP (P2Y $/ \mathrm{P}_{2} \mathrm{Y}_{11}$ agonist), Ap $\mathrm{p}_{4} \mathrm{~A}$ (P2Y 13 agonist), UTP $\left(\mathrm{P}_{2} \mathrm{Y}_{2} / \mathrm{P}_{2} \mathrm{Y}_{4}\right.$ agonist) and UDP (P2Y $\mathrm{Y}_{6}$ agonist) showed no significant effect on IL-10 release (Figure 1).

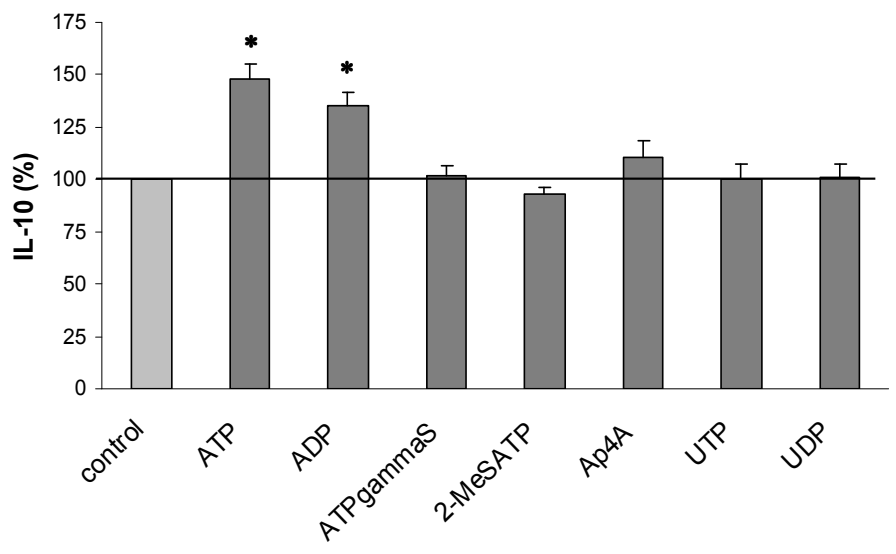

Figure 1: Effect of P2Y receptor agonists on LPS-PHA-induced IL-10 release in whole blood from healthy subjects $(n=6)$. Results are expressed as percentage, with $100 \%$ representing IL-10 release under stimulation by LPS and PHA in the absence of P2Y receptor agonists (=control, indicated by solid line). Bars represent mean values, with error bars representing SEM. ${ }^{*} \mathrm{P}<0.05$ compared to control. 
As a next step, to identify which $\mathrm{P} 2 \mathrm{Y}$ receptors mediated the observed stimulatory effect of ATP on IL-10 release in blood, we combined ATP with different P2 and P1 selective receptor antagonists. To exclude direct effects of the receptor antagonists alone on IL-10 release, we first pre-incubated blood with these antagonists. None of the used P2 or P1 antagonist alone had any effect on IL-10 release in blood (data not shown). We then pre-incubated blood with the same antagonists in the presence of ATP. As shown in figure $2 \mathrm{~A}$ and $2 \mathrm{~B}$, the receptor-selective antagonists such as Ox-ATP (P2X $\mathrm{X}_{7}$ antagonist, $\left.30 \mu \mathrm{M}\right)$, MRS2179 (P2Y ${ }_{1}$ antagonist, $\left.30 \mu \mathrm{M}\right)$, PPADS (P2Y, antagonist, $50 \mu \mathrm{M})$, 5'-AMPS (P2Y 11 antagonist, $100 \mu \mathrm{M})$, MSX-2 $\left(\mathrm{A}_{2 \mathrm{~A}}\right.$ antagonist, $50 \mathrm{nM})$, PSB-1115 $\left(\mathrm{A}_{2 \mathrm{~B}}\right.$ antagonist, $\left.300 \mathrm{nM}\right)$ and PSB-10 $\left(\mathrm{A}_{3}\right.$ antagonist, $5 \mathrm{nM}$ ) did not alter the stimulatory effect of ATP on IL-10 release. PSB-63 (100 nM), an $A_{1}$ antagonist showed only a partial reversion of the ATP-induced IL-10 release (Figure 2B). In contrast, the $\mathrm{P}_{2} \mathrm{Y}_{12 / 13}$ antagonist 2-MeSAMP $(10 \mu \mathrm{M})$ and the selective $\mathrm{P}_{2} \mathrm{Y}_{12}$ antagonist PSB-0413 (25 nM) completely annihilated the ATPinduced IL-10 stimulation (Figure 2A).
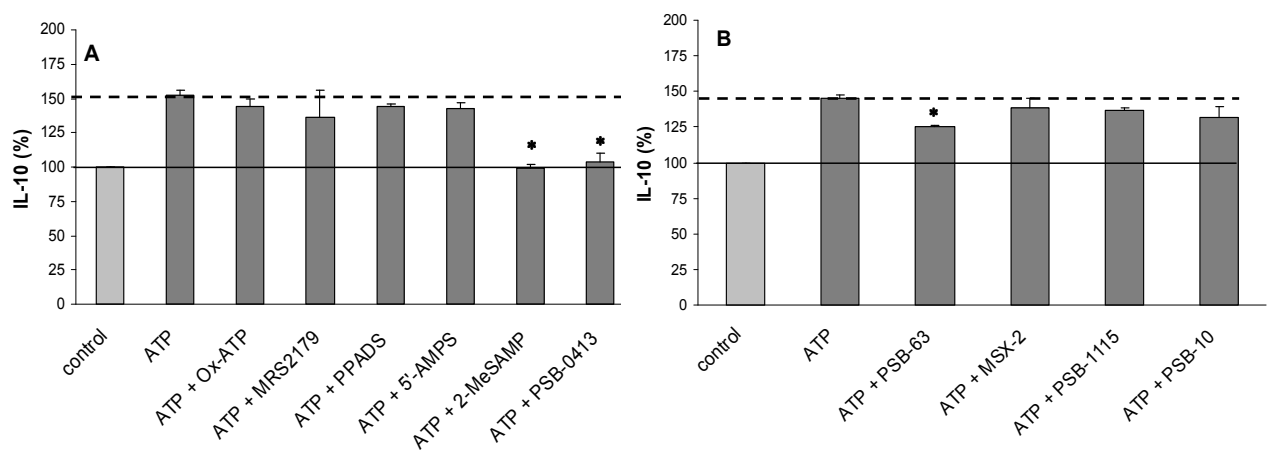

Figure 2: Effect of $P 2(A)$ and $P 1$ receptor antagonists $(B)$ on the ATP-induced stimulation of IL-10 release in LPS-PHA-stimulated whole blood from healthy subjects $(n=6)$. Results are expressed as percentage, with $100 \%$ representing IL-10 release under stimulation by LPS and PHA in the absence of both ATP and receptor antagonists (=control, indicated by solid line). Bars represent mean values, with error bars representing SEM. ${ }^{*} \mathrm{P}<0.05$ compared to the ATP effect in the absence of receptor antagonists (as indicated by the dotted line).

\section{Purinergic receptors involved in the ATP-induced TNF $\alpha$ inhibition}

To investigate the possible mechanism by which ATP inhibits TNF- $\alpha$ release in blood, we first tested the effect of P2 receptor agonists on TNF- $\alpha$ release. Similar to our earlier results [5], ATP strongly inhibited TNF- $\alpha$ release in blood (Figure 3). 
Also the P2Y agonists ADP (P2Y $1 / \mathrm{P}^{2} \mathrm{Y}_{12}$ agonist), ATP $\gamma \mathrm{S}$ (P2Y 11 agonist) and 2MeSATP $\left(P_{2} Y_{1} / P_{2} Y_{11}\right.$ agonist) significantly inhibited TNF- $\alpha$ release. $A p_{4} A\left(P 2 Y_{13}\right.$ agonist), UTP (P2Y ${ }_{2} / \mathrm{P}^{2} \mathrm{Y}_{4}$ agonist) and UDP (P2Y ${ }_{6}$ agonist) had no significant effect on TNF- $\alpha$ release.

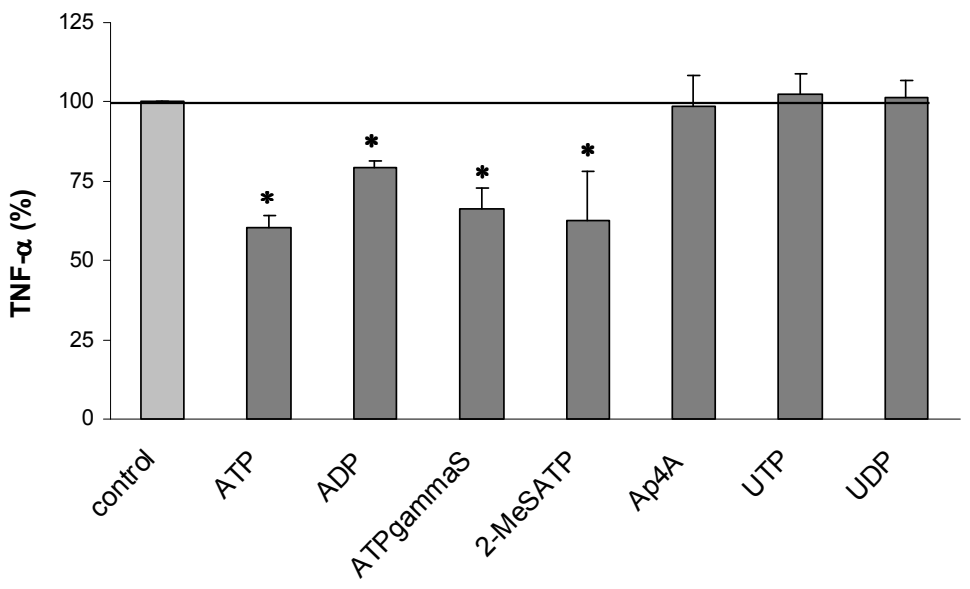

Figure 3: Effect of P2Y receptor agonists on LPS-PHA-induced TNF- $\alpha$ release in whole blood from healthy subjects $(n=6)$. Results are expressed as percentage, with $100 \%$ representing TNF- $\alpha$ release under stimulation by LPS and PHA in the absence of the P2Y receptor agonists (=control, indicated by solid line). Bars represent mean values, with error bars representing SEM. ${ }^{*} \mathrm{P}<0.05$ compared to control.

Again, as a next step, to identify which $\mathrm{P} 2 \mathrm{Y}$ receptors mediated the observed inhibitory effect of ATP on TNF- $\alpha$ release in blood, we incubated ATP in combination with different $\mathrm{P} 2$ and $\mathrm{P} 1$ selective receptor antagonists. Initial tests with $\mathrm{P} 2$ and $\mathrm{P} 1$ receptor antagonists alone confirmed that none of the used antagonists modulated TNF- $\alpha$ release (data not shown). As shown in figure $4 \mathrm{~A}$ and $4 \mathrm{~B}$, incubation of ATP together with the receptor-selective antagonists Ox-ATP (P2X antagonist, $30 \mu \mathrm{M})$, MRS $2179\left(\mathrm{P}_{2} \mathrm{Y}_{1}\right.$ antagonist, $\left.30 \mu \mathrm{M}\right)$, PPADS (P2Y 1 antagonist, $50 \mu \mathrm{M})$, 2-MeSAMP (P2Y $12 / 13$ antagonist, $10 \mu \mathrm{M})$, PSB-0413 (P2Y 12 antagonist, 25 $n M)$, PSB-63 ( $A_{1}$ antagonist, $\left.100 \mathrm{nM}\right), \mathrm{MSX}-2$ ( $\mathrm{A}_{2 \mathrm{~A}}$ antagonist, $\left.50 \mathrm{nM}\right)$, PSB-1115 $\left(A_{2 B}\right.$ antagonist, $\left.300 \mathrm{nM}\right)$ and PSB-10 ( $A_{3}$ antagonist, $\left.5 \mathrm{nM}\right)$ did not alter the inhibitory effect of ATP on TNF- $\alpha$ release. In contrast, the P2Y 11 antagonist 5'AMPS $(100 \mu \mathrm{M})$ completely reversed the ATP-induced TNF- $\alpha$ inhibition (Figure 4A). 

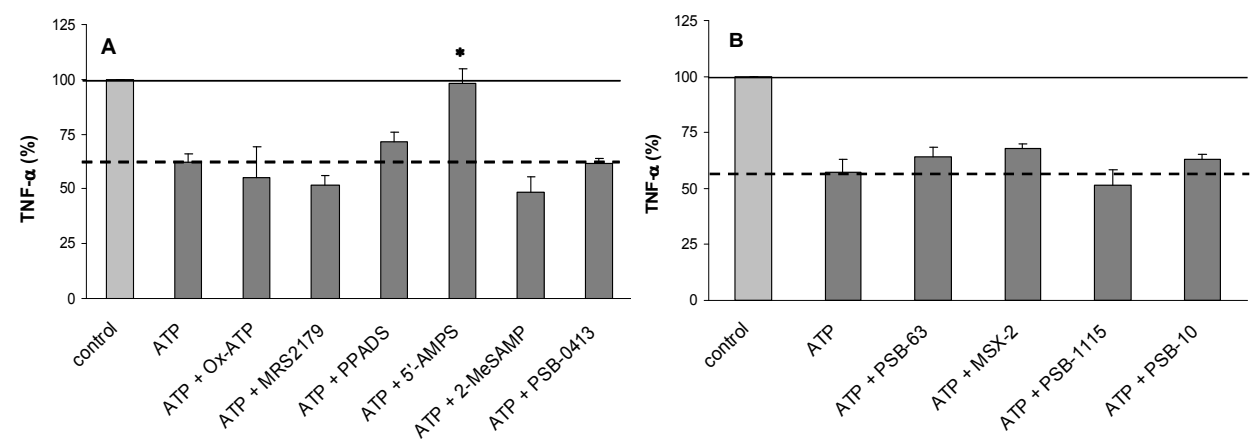

Figure 4: Effect of P2 (A) and P1 receptor antagonists (B) on the ATP-induced inhibition of TNF- $\alpha$ release in LPS-PHA-stimulated whole blood from healthy subjects $(n=6)$. Results are expressed as percentage, with $100 \%$ representing TNF $\alpha$ release under stimulation by LPS and PHA in the absence of both ATP and receptor antagonists (=control, as indicated by solid line). Bars represent mean values, with error bars representing SEM. ${ }^{*} \mathrm{P}<0.05$ compared to the ATP effect in the absence of receptor antagonists (as indicated by the dotted line).

As an next step, we pre-incubated blood with $\mathrm{H}-89$, an inhibitor of cyclic AMP (cAMP)-activated protein kinase A (PKA).

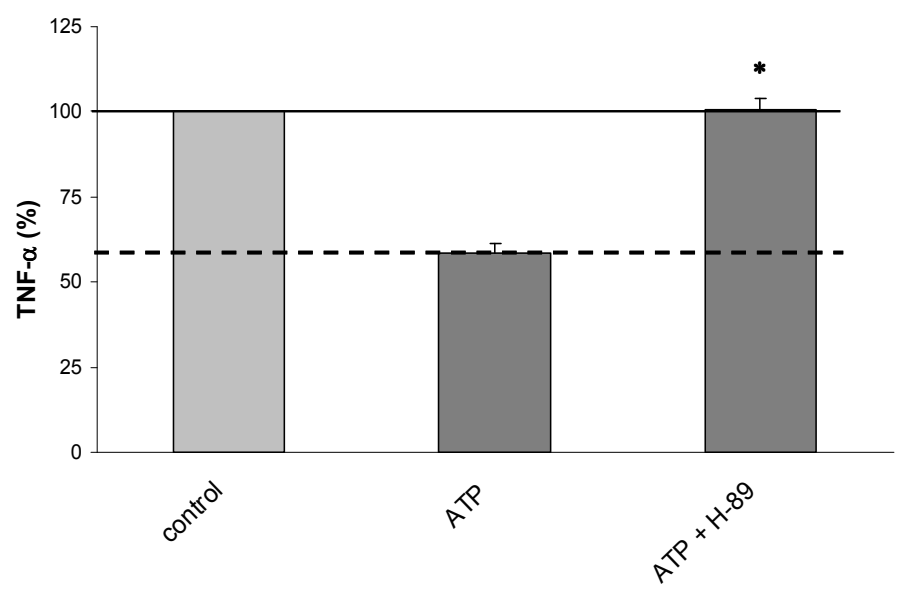

Figure 5: Effect of H-89 on ATP-induced inhibition of TNF- $\alpha$ release in LPS-PHA-stimulated whole blood from healthy subjects $(n=6)$. Results are expressed in percentage, with $100 \%$ representing TNF- $\alpha$ release under stimulation by LPS and PHA in the absence of ATP and H-89 (=control, as indicated by the solid line). $\mathrm{H}-89$ alone had no effect on cytokine release (data not shown). Bars represent mean values, with error bars representing SEM. ${ }^{*} \mathrm{P}<0.05$ compared to the ATP effect in the absence of $\mathrm{H}-89$ (indicated by the dotted line). 
$\mathrm{H}-89(10 \mu \mathrm{M})$ completely blocked the ATP-induced inhibition of TNF- $\alpha$ release (Figure 5).

To corroborate the effect that arises from cAMP activation, we incubated blood with forskolin, an adenylyl cyclase (AC) activator. Results showed that $10 \mu \mathrm{M}$ of forskolin significantly inhibited LPS-PHA-induced TNF- $\alpha$ release (32 $\pm 2 \%$ inhibition), mimicking the effect of ATP ( $41 \pm 2 \%$ inhibition).

\section{Discussion}

We recently reported that micromolar concentrations of the physiological compound ATP inhibit the release of the pro-inflammatory cytokine TNF- $\alpha$, and stimulate the release of the anti-inflammatory cytokine IL-10, in LPS-PHA-stimulated whole blood [5]. The aim of the present study was to identify the receptors involved in these effects of ATP. ATP and its breakdown product adenosine are known to regulate a wide variety of physiological processes via $\mathrm{P} 2$ and $\mathrm{P} 1$ receptors, respectively. The $\mathrm{P} 2$ receptor family is subdivided in two subfamilies, i.e. P2X and P2Y [7]. P2Y receptors are seven-transmembrane receptors of which eight subtypes have been identified to date $\left(\mathrm{P} 2 \mathrm{Y}_{1}, \mathrm{P}_{2} \mathrm{Y}_{2}, \mathrm{P}_{2} \mathrm{Y}_{4}, \mathrm{P} 2 \mathrm{Y}_{6}, \mathrm{P} 2 \mathrm{Y}_{11}, \mathrm{P} 2 \mathrm{Y}_{12}, \mathrm{P} 2 \mathrm{Y}_{13}, \mathrm{P} 2 \mathrm{Y}_{14}\right)$ [9, 20-23], whereas $\mathrm{P} 2 \mathrm{X}$ receptors are ligand-gated ion channels of which seven subtypes have been characterized $\left(\mathrm{P}_{2} \mathrm{X}_{1-7}\right)$ [24, 25]. With respect to the present study, it is particularly relevant that extracellular nucleotides exert numerous actions via several $\mathrm{P} 2 \mathrm{X}$ and $\mathrm{P} 2 \mathrm{Y}$ receptors present on different cell types such as monocytes, macrophages, dendritic cells, lymphocytes, platelets and erythrocytes [6]. P1 receptors belong to the superfamily of seven-transmembrane receptors and are subdivided into $A_{1}, A_{2 A}, A_{2 B}$ and $A_{3}$ receptor subtypes [9, 26, 27].

Among the $\mathrm{P} 2 \mathrm{Y}$ receptors, $\mathrm{P} 2 \mathrm{Y}_{11}$ is the only ATP-selective receptor. $\mathrm{P} 2 \mathrm{Y}_{1}, \mathrm{P}_{2} \mathrm{Y}_{12}$, and $P 2 Y_{13}$ prefer ADP; at $P 2 Y_{2}$, ATP and UTP are equipotent [20, 21, 28]; $P 2 Y_{4}$ is preferentially activated by UTP, $P 2 Y_{6}$ is UDP-selective and the $\mathrm{P}_{2} \mathrm{Y}_{14}$ receptor subtype is activated by the nucleotide sugar UDPglucose [29]. After binding of their cognate ligands, most $\mathrm{P} 2 \mathrm{Y}$ receptors $\left(\mathrm{P} 2 \mathrm{Y}_{1}, \mathrm{P}_{2} \mathrm{Y}_{2}, \mathrm{P}_{2} \mathrm{Y}_{4}\right.$ and $\left.\mathrm{P} 2 \mathrm{Y}_{6}\right)$ initiate signaling through $\mathrm{G}_{\mathrm{q}}$-proteins, activating phospholipase (PLC), which in turn increases inositol 1,4,5-triphosphate $\left(\mathrm{IP}_{3}\right)$ and thereby results in mobilization of $\mathrm{Ca}^{2+}$ from intracellular stores. Unlike the $\mathrm{G}_{\mathrm{q}}$-coupled $\mathrm{P} 2 \mathrm{Y}_{1}$ receptor, the ADP-selective $P 2 \mathrm{Y}_{12}$ and $P 2 Y_{13}$ receptors both use $G_{i}$ proteins to inhibit $A C$. $P 2 Y_{11}$ has the remarkable and unique property among the P2Y family of being dually coupled to $G_{q}$, thereby activating the PLC pathway, and to $G_{s}$, which leads to $A C$ activation $[20,21,23]$. Furthermore, the human $\mathrm{P}_{2} \mathrm{Y}_{11}$-receptor is the only cloned P2Y-receptor that is selective for ATP as a naturally occurring agonist [20]. This $\mathrm{P}_{2} \mathrm{Y}_{11}$ receptor is highly expressed in immunocytes and may play a role in the differentiation of these cells [30].

We here present data demonstrating that $\mathrm{P}_{2} \mathrm{Y}_{11}$ is the mediator of the ATP-induced inhibition of TNF- $\alpha$ release in blood and that this activation occurs through PKA 
stimulation coupled to cAMP as a second messenger. Importantly, our data show that the ATP-induced stimulation of $\mathrm{IL}-10$ release in blood is mediated through a completely different receptor, i.e. the $\mathrm{P}_{2} \mathrm{Y}_{12}$ receptor, suggesting an ADP effect and a cAMP inhibition pathway. Our finding that the ATP-induced effect on TNF- $\alpha$ and $\mathrm{IL}-10$ release is mediated via $\mathrm{P} 2$ receptors and not via $\mathrm{P} 1$ receptors corroborates and expands on our recent report [5] which showed that the effect of ATP on cytokine release was not blocked by adenosine deaminase.

In the present study, the involvement of the $\mathrm{P}_{2} \mathrm{Y}_{11}$ receptor in the ATP-induced inhibition of TNF- $\alpha$ was demonstrated by pre-incubation of blood with 5'-AMPS prior to incubation with ATP. 5'-AMPS is a selective inhibitor of P2Y 11 , since it was shown that 5'-AMPS inhibited ATP-induced cAMP accumulation in transfected haematological cell lines [31] and in human B-lymphocytes from patients with chronic lymphocytic leukemia [32], which stably expressed the $\mathrm{P}_{2} \mathrm{Y}_{11}$ receptor. We here show that 5'-AMPS completely reversed the inhibitory effect of ATP on TNF- $\alpha$ release in blood, indicating $P 2 Y_{11}$ as the receptor through which ATP inhibits TNF- $\alpha$ release. Consistent with this conclusion, the potent $\mathrm{P}_{2} \mathrm{Y}_{11}$ receptor agonist ATP $\gamma \mathrm{S}$, and 2-MeSATP, which also acts on $\mathrm{P}_{2 Y_{11}}$ receptors, inhibited TNF- $\alpha$ release. Based on our data, the involvement of other $\mathrm{P} 2 \mathrm{Y}$ receptors in the ATP-mediated effect on TNF- $\alpha$ release can be excluded, since the $P 2 Y_{1}, P 2 Y_{12}$ and $P 2 Y_{13}$ antagonists did not interfere with the ATP-induced TNF- $\alpha$ inhibition. Moreover, the lack of a UTP and UDP effect is inconsistent with a role of $\mathrm{P}_{2} \mathrm{Y}_{2}, \mathrm{P}_{2} \mathrm{Y}_{4}$ or $\mathrm{P} 2 \mathrm{Y}_{6}$ receptor. In contrast to the ATP-induced inhibition of TNF- $\alpha$, our data demonstrate that the IL-10 stimulation by ATP in blood is mediated through the $\mathrm{P}_{2} \mathrm{Y}_{12}$ receptor, as shown by the observation that the stimulatory effect of ATP on IL-10 was completely annihilated both by $P 2 Y_{12} / P 2 Y_{13}$ and by selective $P 2 Y_{12}$ receptor antagonists. Moreover, ADP as a $\mathrm{P}_{2} \mathrm{Y}_{12}$ agonist showed a stimulatory effect on IL-10 release, like ATP.

Because the $\mathrm{P}_{2} \mathrm{Y}_{11}$ receptor is the only known $\mathrm{P} 2 \mathrm{Y}$ receptor coupled to $\mathrm{AC}$ activation, we speculated that an increase in CAMP, induced via $P 2 Y_{11}$ activation, might be responsible for the inhibition of TNF- $\alpha$ release by ATP. In support of this notion, we showed that direct activation of AC with forskolin inhibited LPS-PHAinduced TNF- $\alpha$ production in blood, though less effectively than ATP. To confirm the involvement of the $\mathrm{P}_{2} \mathrm{Y}_{11}$ receptor in the ATP-induced TNF- $\alpha$ inhibition, we incubated blood with ATP in the presence of $\mathrm{H}-89$, a potent inhibitor of cAMPactivated PKA. We were thus able to show that the process whereby ATP inhibits TNF- $\alpha$ release is dependent on PKA stimulation by CAMP, indicating the involvement of the $\mathrm{P}_{2} \mathrm{Y}_{11}$ receptor. Stimulation of $\mathrm{P}_{2} \mathrm{Y}_{11}$ receptors by nucleotides has been associated with increased generation of cAMP production in many cell types [31-33]. It was hypothesized that cAMP signal transduction pathways may modulate the activity of nuclear factor kappaB $(N F \kappa B)$ by regulating its phosphorylation state, thereby modulating the cytokine biosynthesis [34]. 
In conclusion, our data show that upon stimulation with ATP, P2Y 11 is activated, followed by CAMP-induced PKA stimulation and subsequent down-regulation of TNF- $\alpha$ release. On the other hand, ATP also stimulates P2Y $Y_{12}$, possibly via its breakdown product ADP, thereby leading to an increase in IL-10 release. Thus, ATP is able to down-regulate the pro-inflammatory cytokine TNF- $\alpha$ by $\mathrm{P}_{2} \mathrm{Y}_{11}$ activation, and to simultaneously up-regulate the anti-inflammatory cytokine IL-10 by P2Y 12 activation in human blood. Such a concerted modulation, which involves alteration of the balance among pro- and anti-inflammatory cytokines, implicates a significant novel approach in the treatment of chronic inflammatory diseases, especially in cases where the disease process is complex and involves simultaneous deregulation of many different cytokines. 


\section{References}

1 Reimold A.M. New indications for treatment of chronic inflammation by TNF-alpha blockade. Am J Med Sci 2003; 325: 75-92.

2 Atzeni F., Sarzi-Puttini P., Doria A., laccarino L. and Capsoni F. Potential off-label use of infliximab in autoimmune and non-autoimmune diseases: a review. Autoimmun Rev 2005; 4: 144-152.

3 Crum N.F., Lederman E.R. and Wallace M.R. Infections associated with tumour necrosis factor-alpha antagonists. Medicine (Baltimore) 2005; 84: 291-302.

4 Bakleh M., Tleyjeh I., Matteson E.L., Osmon D.R. and Berbari E.F. Infectious complications of tumour necrosis factor-alpha antagonists. Int J Dermatol 2005; 44: 443-448.

5 Swennen E.L., Bast A. and Dagnelie P.C. Immunoregulatory effects of adenosine 5'triphosphate on cytokine release from stimulated whole blood. Eur J Immunol 2005; 35: 852858.

6 Di Virgilio F., Chiozzi P., Ferrari D., Falzoni S., Sanz J.M., Morelli A., Torboli M., Bolognesi G. and Baricordi O.R. Nucleotide receptors: an emerging family of regulatory molecules in blood cells. Blood 2001; 97: 587-600.

7 Burnstock G. and Knight G.E. Cellular distribution and functions of P2 receptor subtypes in different systems. Int Rev Cytol 2004; 240: 31-304.

8 Ferrari D., La Sala A., Chiozzi P., Morelli A., Falzoni S., Girolomoni G., Idzko M., Dichmann S., Norgauer J. and Di Virgilio F. The P2 purinergic receptors of human dendritic cells: identification and coupling to cytokine release. Faseb J 2000; 14: 2466-2476.

9 Ralevic V. and Burnstock G. Receptors for purines and pyrimidines. Pharmacol Rev 1998; 50: 413-492.

10 Hasko G. and Cronstein B.N. Adenosine: an endogenous regulator of innate immunity. Trends Immunol 2004; 25: 33-39.

11 Sitkovsky M.V. Use of the $\mathrm{A}(2 \mathrm{~A})$ adenosine receptor as a physiological immunosuppressor and to engineer inflammation in vivo. Biochem Pharmacol 2003; 65: 493-501.

12 El-Tayeb A., Griessmeier K.J. and Muller C.E. Synthesis and preliminary evaluation of [3H]PSB-0413, a selective antagonist radioligand for platelet P2Y12 receptors. Bioorg Med Chem Lett 2005; 15: 5450-5452.

13 Weyler S., Hayallah A.M. and Muller C.E. Versatile, convenient synthesis of pyrimido[1,2,3cd]purinediones. Tetrahedron 2003; 59: 47-54.

14 Sauer R., Maurinsh J., Reith U., Fulle F., Klotz K.N. and Muller C.E. Water-soluble phosphate prodrugs of 1-propargyl-8-styrylxanthine derivatives, $\mathrm{A}(2 \mathrm{~A})$-selective adenosine receptor antagonists. J Med Chem 2000; 43: 440-448.

15 Hockemeyer J., Burbiel J.C. and Muller C.E. Multigram-scale syntheses, stability, and photoreactions of A2A adenosine receptor antagonists with 8-styrylxanthine structure: potential drugs for Parkinson's disease. J Org Chem 2004; 69: 3308-3318.

16 Ozola V., Thorand M., Diekmann M., Qurishi R., Schumacher B., Jacobson K.A. and Muller C.E. 2-Phenylimidazo[2,1-i]purin-5-ones: structure-activity relationships and characterization of potent and selective inverse agonists at Human A3 adenosine receptors. Bioorg Med Chem 2003; 11: 347-356.

17 Burbiel J.C., Thorand M. and Muller C.E. Improved, efficient synthesis for multigram-scale production of PSB-10, a potent antagonist at human A3 adenosine receptors. Heterocycles 2003; 60: 1425-1432.

18 Hayallah A.M., Sandoval-Ramirez J., Reith U., Schobert U., Preiss B., Schumacher B., Daly J.W. and Muller C.E. 1,8-disubstituted xanthine derivatives: synthesis of potent A2B-selective adenosine receptor antagonists. J Med Chem 2002; 45: 1500-1510. 
19 Abo-Salem O.M., Hayallah A.M., Bilkei-Gorzo A., Filipek B., Zimmer A. and Muller C.E. Antinociceptive effects of novel A2B adenosine receptor antagonists. J Pharmacol Exp Ther 2004; 308: 358-366.

20 von Kugelgen I. and Wetter A. Molecular pharmacology of P2Y-receptors. Naunyn Schmiedebergs Arch Pharmacol 2000; 362: 310-323.

21 Communi D., Janssens R., Suarez-Huerta N., Robaye B. and Boeynaems J.M. Advances in signalling by extracellular nucleotides. the role and transduction mechanisms of P2Y receptors. Cell Signal 2000; 12: 351-360.

22 Burnstock G. and Williams M. P2 purinergic receptors: modulation of cell function and therapeutic potential. J Pharmacol Exp Ther 2000; 295: 862-869.

23 Communi D., Robaye B. and Boeynaems J.M. Pharmacological characterization of the human P2Y11 receptor. Br J Pharmacol 1999; 128: 1199-1206.

24 Khakh B.S., Burnstock G., Kennedy C., King B.F., North R.A., Seguela P., Voigt M. and Humphrey P.P. International union of pharmacology. XXIV. Current status of the nomenclature and properties of P2X receptors and their subunits. Pharmacol Rev 2001; 53: 107-118.

25 North R.A. Molecular physiology of P2X receptors. Physiol Rev 2002; 82: 1013-1067.

26 Fredholm B.B., AP I.J., Jacobson K.A., Klotz K.N. and Linden J. International Union of Pharmacology. XXV. Nomenclature and classification of adenosine receptors. Pharmacol Rev 2001; 53: 527-552.

27 Muller C.E. Medicinal chemistry of adenosine A3 receptor ligands. Curr Top Med Chem 2003; 3: $445-462$.

28 Marteau F., Le Poul E., Communi D., Labouret C., Savi P., Boeynaems J.M. and Gonzalez N.S. Pharmacological characterization of the human P2Y13 receptor. Mol Pharmacol 2003; 64: 104-112.

29 Brunschweiger A. and Muller C.E. P2 receptors activated by uracil nucleotides--an update. Curr Med Chem 2006; 13: 289-312.

30 Communi D., Govaerts C., Parmentier M. and Boeynaems J.M. Cloning of a human purinergic P2Y receptor coupled to phospholipase C and adenylyl cyclase. J Biol Chem 1997; 272: 31969-31973.

31 van der Weyden L., Adams D.J., Luttrell B.M., Conigrave A.D. and Morris M.B. Pharmacological characterisation of the $\mathrm{P} 2 \mathrm{Y} 11$ receptor in stably transfected haematological cell lines. Mol Cell Biochem 2000; 213: 75-81.

32 Conigrave A.D., Fernando K.C., Gu B., Tasevski V., Zhang W., Luttrell B.M. and Wiley J.S. P2Y(11) receptor expression by human lymphocytes: evidence for two cAMP-linked purinoceptors. Eur J Pharmacol 2001; 426: 157-163.

33 Duhant X., Schandene L., Bruyns C., Gonzalez N.S., Goldman M., Boeynaems J.M. and Communi D. Extracellular adenine nucleotides inhibit the activation of human CD4+ T lymphocytes. J Immunol 2002; 169: 15-21.

34 Haraguchi S., Good R.A. and Day N.K. Immunosuppressive retroviral peptides: cAMP and cytokine patterns. Immunol Today 1995; 16: 595-603. 



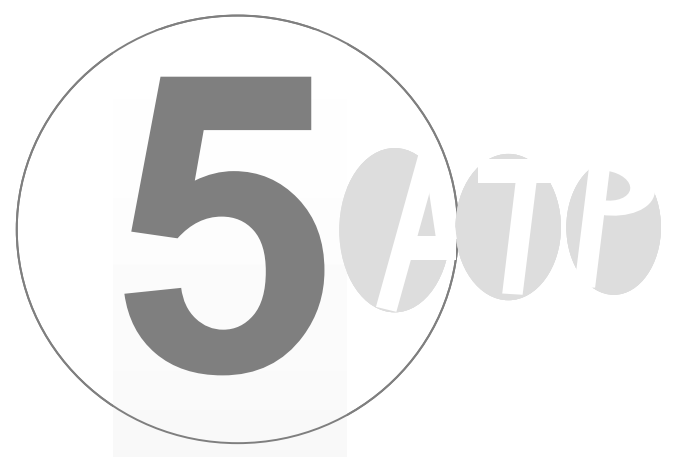

Time-dependent effects of ATP and its degradation products on inflammatory markers in human blood ex vivo

Els L.R. Swennen

Erik J.C.M. Coolen Ilja C.W. Arts

Aalt Bast

Pieter C. Dagnelie

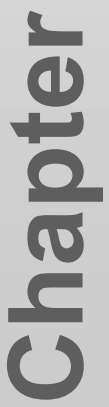

Submitted 


\begin{abstract}
We recently reported that adenosine 5'-triphosphate (ATP) modulates cytokine release in lipopolysaccharide (LPS)-phytohemagglutinin (PHA)-stimulated blood. ATP inhibited tumour necrosis factor-alpha (TNF- $\alpha$ ) release via activation of the $\mathrm{P}_{2} \mathrm{Y}_{11}$ receptor and increased interleukin (IL)-10 release via stimulation of the $\mathrm{P}_{2} \mathrm{Y}_{12}$ receptor. Because ATP is known to be broken down by various ecto-enzymes, we determined the degradation profile of ATP in time in LPS-PHA-stimulated blood. ATP slowly metabolized with $14 \%$ remaining after $6 \mathrm{~h}$. Simultaneously, adenosine 5'-diphosphate (ADP), adenosine 5'-monophosphate (AMP) and hypoxanthine were formed. Subsequently, we investigated the time-dependent effects of ATP and its metabolites on inflammatory markers. Results showed that ATP decreased the rise in concentrations of TNF- $\alpha$, interferon-gamma (IFN- $\gamma$ ) and IL-1 $1 \beta$, but increased concentrations of IL-8 and IL-10. Metabolites of ATP showed either no, similar or opposite effects on cytokine release, compared to ATP. In conclusion, ATP has rapid immunomodulatory effects on a variety of cytokines in stimulated whole blood that persist until $24 \mathrm{~h}$.
\end{abstract}




\section{Introduction}

Purinergic receptors are known to mediate the variety of effects induced by extracellular adenosine 5'-triphosphate (ATP) [1-3]. Extracellular ATP modulates cytokine release induced by several inflammatory stimulators (lipopolysaccharide (LPS), cytokine mix, etc.) in different cell lines [4]. However, ATP is metabolized by various ecto-enzymes [5] to adenosine 5'-diphosphate (ADP) and adenosine 5'monophosphate (AMP). AMP can be further degraded to adenosine, inosine and hypoxanthine and eventually to uric acid.

We showed earlier that ATP modulates cytokine release in LPSphytohemagglutinin (PHA)-stimulated blood, a model closely resembling the in vivo situation in contrast with most studies done in cell lines, by inhibiting tumour necrosis factor-alpha (TNF- $\alpha$ ) and increasing interleukin (IL)-10 release [6]. In a subsequent study [7], we showed that the inhibitory effect of ATP on TNF- $\alpha$ release observed $24 \mathrm{~h}$ after stimulation was mediated by activation of the $\mathrm{P} 2 \mathrm{Y}_{11}$ receptor. Since this receptor is preferentially activated by ATP [8-11], this would indicate a possible direct effect of ATP without the involvement of its metabolites. In contrast, the involvement of the P2Y 12 receptor, a receptor activated by ADP [10, 12], in the stimulatory effect of ATP on IL-10 release observed $24 \mathrm{~h}$ after stimulation, suggested that this effect was due to its metabolite ADP. At present, it is unclear whether ATP modulates cytokine release at earlier time-points than $24 \mathrm{~h}$ after stimulation and, moreover, if ATP is able to modulate the release of other cytokines like interferon-gamma (IFN- $\gamma$ ), IL-1 $\beta$ and IL-8 in stimulated human blood.

In the present study, we intended to further characterize the ATP effects in this LPSPHA-stimulated blood model and the behaviour of ATP in this model. The primary aim of the present study was therefore, first to determine the degradation profile of ATP and, second, to investigate the time-dependent effect of ATP and its metabolites on the release of the cytokines TNF- $\alpha$, IFN- $\gamma$, IL-1 $1 \beta$, IL-8 and IL-10 in LPS-PHA-stimulated blood. Since the transcription factor nuclear factor kappaB $(\mathrm{NF} K \mathrm{~B})$ is activated during an inflammatory response [13-15], we further investigated whether the anti-inflammatory effects of ATP were due to interference with the NFKB pathway.

\section{Material and methods}

\section{Chemicals}

Purified PHA (HA16) was purchased from Murex, Dartford, UK. LPS (E.coli 0.26:B6), ADP, AMP, adenine, adenosine, inosine, hypoxanthine, uric acid and bovine serum albumin (BSA) were obtained from Sigma Chemical Co., St. Louis, USA. ATP was purchased from Calbiochem, USA. 
Human enzyme linked immune sorbent assay (ELISA) kits (TNF- $\alpha$, IFN- $\gamma$, IL-1 $\beta$, IL8 and IL-10) were obtained from CLB/Sanquin, Amsterdam, The Netherlands. RPMI 1640 medium containing L-glutamine was obtained form Gibco, Paisly, UK. Bio-Rad protein assay Dye reagent concentrate was obtained from Bio-Rad Laboratories $\mathrm{GmbH}$, Munich, Germany. All other chemicals were of analytical purity.

\section{Study design}

Blood was collected from twelve healthy volunteers (age range 25-36 years; 6 women en 6 men) in heparin-containing vacutainer tubes (Vacutainer, BectonDickinson, $170 \mathrm{IU})$. Fresh blood was aliquoted into 6 or 24-well plates and incubated with medium (control) or ATP, ADP, AMP, adenosine, inosine, hypoxanthine or uric acid at $t=-30$ min followed by LPS-PHA incubation at $t=0$. Consequently, the blood was diluted four times and the final concentration of ATP and the other compounds was $300 \mu \mathrm{M}$ at $\mathrm{t}=0$. Samples for analysis of cytokines, NF $\kappa B, A T P$ and its metabolites were taken at time-points $\mathrm{t}=0$, 15, $30 \mathrm{~min}$ and 1, 2, 4, 6 and $24 \mathrm{~h}$ after LPS-PHA stimulation. All the incubations were done at $5 \% \quad \mathrm{CO}_{2}$ and $37^{\circ} \mathrm{C}$ as previously described [6]. PHA and bacterial LPS were added to whole blood at a concentration of $1 \mu \mathrm{g} / \mathrm{ml}$ and $10 \mu \mathrm{g} / \mathrm{ml}$ respectively. After each incubation period, cell-free supernatant fluids were collected by centrifugation $(3500 \mathrm{rpm}, 10 \mathrm{~min}$ at $4^{\circ} \mathrm{C}$ ) and stored at $-20^{\circ} \mathrm{C}$ for cytokine analysis and at $-80^{\circ} \mathrm{C}$ for measurement of the concentrations of ATP and its metabolites. To isolate white blood cells, the pellet remaining after centrifugation of the blood was washed 3 times with erythrocyte lysis buffer (containing $\mathrm{NH}_{4} \mathrm{Cl}, \mathrm{KHCO}_{3}$ and EDTA) and placed on ice to lyse the erythrocytes. The white blood cell pellets were surface washed with ice-cold PBS, centrifuged and the supernatant was discarded. Subsequently, the white blood cell pellets were lysed using an ice-cold lysis buffer as described by Hofmann et al. [16] and centrifuged at $15000 \mathrm{rpm}$ for $1 \mathrm{~min}$ at $4^{\circ} \mathrm{C}$. The nuclear pellets were resuspended in ice-cold extraction buffer as described by Hofmann et al. [16]. After $20 \mathrm{~min}$ at $4^{\circ} \mathrm{C}$, the nuclear lysates were centrifuged at $15000 \mathrm{rpm}$ for $2 \mathrm{~min}$ at $4^{\circ} \mathrm{C}$ and the supernatants, containing the nuclear proteins, were immediately collected and stored at $-80^{\circ} \mathrm{C}$ until analysis of $\mathrm{NF} \kappa \mathrm{B}$ and protein concentration.

\section{Cytokine measurement via ELISA}

All cytokines were quantified using PeliKine Compact human ELISA kits (CLB/Sanquin, The Netherlands) based on appropriate and validated sets of monoclonal antibodies. Assays were performed as described by the manufacturer's instructions. 


\section{NFKB and protein measurement}

NF $\kappa B$ concentrations were determined in nuclear extracts of white blood cells, according to the manufacturer's instructions (TransAM NFKB p50 transcription Factor Assay Kit; Active Motif Europe, Rixensart, Belgium), using a protein content of $200-300 \mu \mathrm{g} / \mathrm{ml}$ in the nuclear extracts; protein concentrations were determined using the method of Bradford (Biorad), using bovine serum albumin as a standard. Specific NFKB concentrations in the nuclear extracts were determined using a wildtype oligonucleotide incubation versus a mutated oligonucleotide incubation.

\section{ATP measurement in plasma by high performance liquid chromatography (HPLC)}

The analyses of the concentrations of ATP, ADP, AMP, adenosine, inosine, hypoxanthine and uric acid were done according to the method described by Schweinsberg et al. [17] with minor modifications. Plasma samples were deproteinized with a final concentration of $4 \%$ perchloric acid. The supernatant was neutralized ( $\mathrm{pH} \mathrm{6-7)}$ with $2 \mathrm{M} \mathrm{K}_{2} \mathrm{CO}_{3}$ in $6 \mathrm{M} \mathrm{KOH}$ and centrifuged (14.000 rpm, 10 min, $4^{\circ} \mathrm{C}$ ). In a single run, ATP and its metabolites were quantified using an HPLC system (Agilent, Palo Alto, CA, USA) equipped with a UVIVIS detector (254 nm). Separation was achieved with a $3 \mu \mathrm{m}$ ODS Hypersil C18 RP column $(150 \times 4.6 \mathrm{~mm}$ i.d.; Thermo Electron Corp., USA) protected by a $5 \mu \mathrm{m}$ Hypersil C18 guard column $(10 \times 4 \mathrm{~mm}$ i.d.; Alltech BV, Breda, The Netherlands). $50 \mathrm{mM}$ phosphate buffer $(\mathrm{pH}$ 6.0) (mobile phase A), 100\% methanol (mobile phase B) and a flow of $1 \mathrm{ml} / \mathrm{min}$ were employed. From 0 to $2 \mathrm{~min}$, a linear gradient was started with $100 \%$ mobile phase A, from 2-10 min the amount of mobile phase $B$ was linearly increased to $12.5 \%$ and remained for $2 \mathrm{~min}$ at $12.5 \%$. Finally, the amount of methanol was reduced to $0 \%$ and the gradient returned to $100 \%$ mobile phase $A$ at $17 \mathrm{~min}$. Concentrations of ATP and its metabolites were calculated by comparing peak areas with appropriate standards.

\section{Statistics}

Changes in cytokine release and NFKB activation compared to time-point $0 \mathrm{~h}$ were appraised by Wilcoxon's signed rank test, and effects of ATP and its metabolites on cytokine release compared to the control condition (medium) were determined using Mann-Whitney-U-test. Two-tailed P-values of 0.05 or less were considered statistically significant. Results are reported as means \pm SEM. 


\section{Results}

\section{ATP degradation profile in LPS-PHA-stimulated human blood}

Figure 1 shows the time-dependent degradation of ATP and the simultaneous formation of its metabolites ADP, AMP and hypoxanthine in human blood at different time-points after LPS-PHA stimulation. Other known metabolites of ATP, such as xanthine, adenosine, adenine or inosine were not detected.

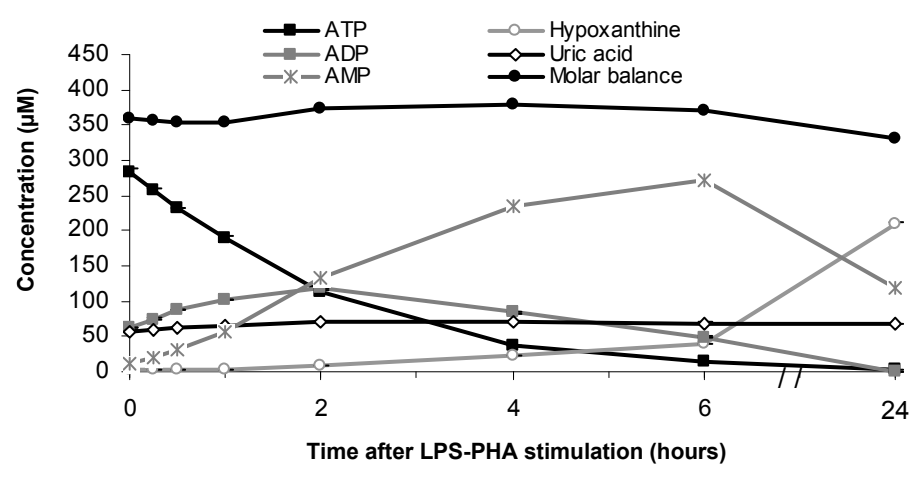

Figure 1: Degradation profile of ATP at different time-points after LPS-PHA stimulation in diluted blood from healthy subjects. The concentration of each of the detected components is plotted on the $\mathrm{Y}$-axis. The ATP concentration at $\mathrm{t}=0$ was $300 \mu \mathrm{M}$. Curves represent means, and error bars SEM $(n=6)$.

The molar balance (which is determined as the sum of the molar concentrations of ATP and its metabolites) in the samples remained stable during the experiment. Fifty-five \% of the initial concentration of ATP was degraded after $2 \mathrm{~h}$. After 6 hours, $86 \%$ was degraded. As the ATP concentration declined, both ADP and AMP were formed. The ADP concentrations increased two-fold after $2 \mathrm{~h}$, followed by a gradual decrease. At $24 \mathrm{~h}$, no detectable levels of ATP and ADP were left. AMP levels increased up to twenty-fold after $6 \mathrm{~h}$, followed by a decrease after $24 \mathrm{~h}$. Hypoxanthine levels showed a gradual rise from 2-6 h, with an increase after $24 \mathrm{~h}$. Uric acid levels remained constant at $60 \mu \mathrm{M}$. The ATP breakdown profile in blood not treated with LPS-PHA was similar (data not shown). Furthermore, control experiments showed that no ATP was formed in blood treated with LPS-PHA only (data not shown). 


\section{Effects of ATP on inflammatory markers at different time-points after LPS-PHA stimulation}

Figures 2A-2F show the effects of ATP on different cytokines in human blood at 2, 4,6 and $24 \mathrm{~h}$ after LPS-PHA stimulation.
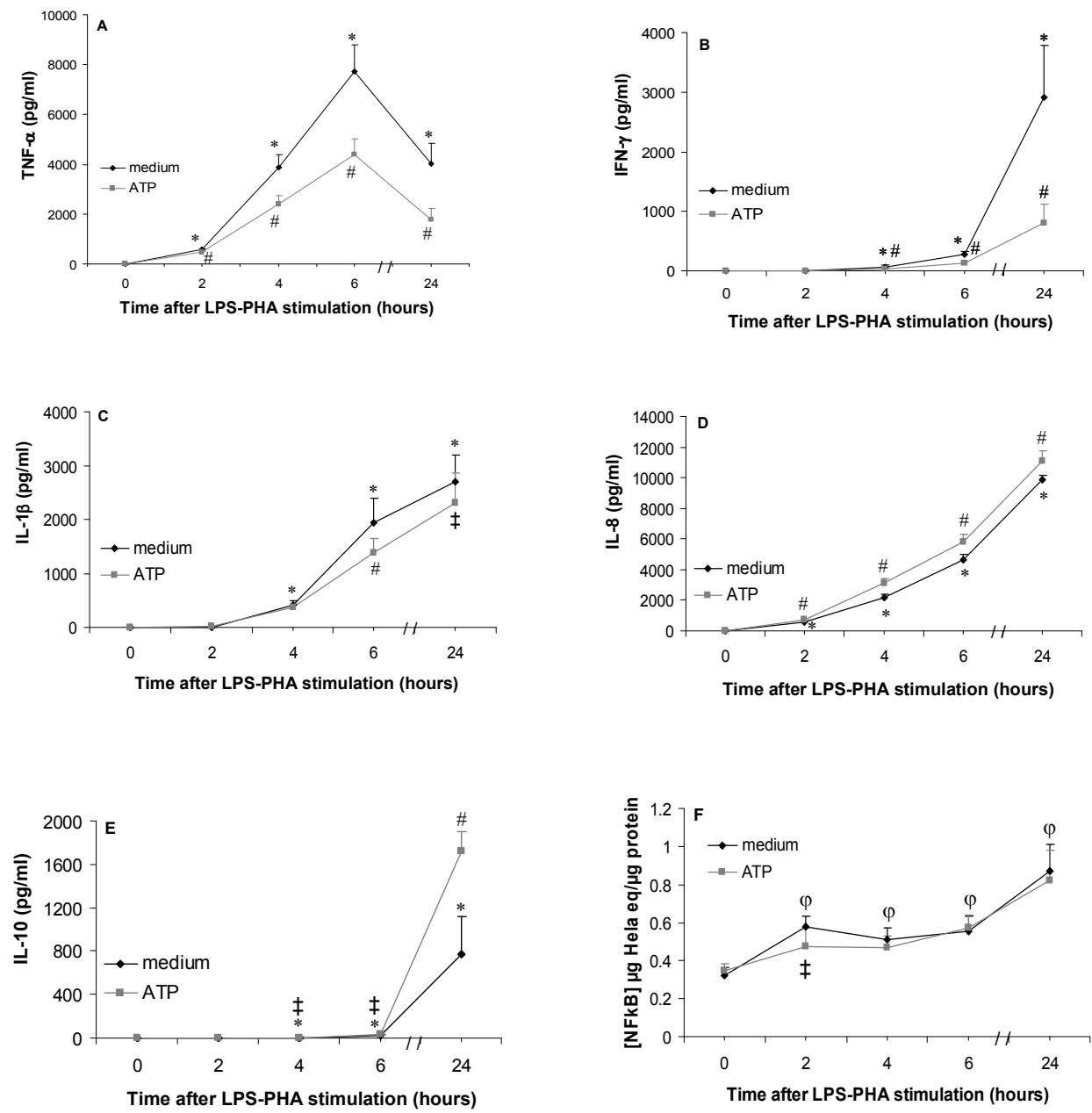

Figure 2 (A-F): Modulating effects of ATP $(300 \mu \mathrm{M})$ on TNF- $\alpha$ (A), IFN- $\gamma(B)$, IL-1 $\beta$ (C), IL-8 (D), IL$10(E)$ concentrations and $N F \kappa B(F)$ activation induced at different time-points $(0,2,4,6$ and $24 \mathrm{~h})$ after LPS-PHA stimulation in blood from healthy subjects. Curves represent means, and error bars SEM ( $n=12) .{ }^{*} \mathrm{P}<0.01$ and ${ }^{\varphi} \mathrm{P}<0.05$ compared to $0 \mathrm{~h}$ after LPS-PHA stimulation. ${ }^{\#} \mathrm{P}<0.01$ and ${ }^{ \pm} \mathrm{P}<0.05$ compared to stimulation in the absence of ATP. 
TNF- $\alpha$ concentrations increased between 2 and $6 \mathrm{~h}$ after LPS-PHA stimulation, but decreased thereafter (Figure 2A). ATP pre-treatment of blood attenuated the rise in TNF- $\alpha$ concentrations at all time-points (mean \pm SEM: $21 \pm 3 \%$ at $2 \mathrm{~h}, 41 \pm 3 \%$ at 4 $\mathrm{h}, 42 \pm 2 \%$ at $6 \mathrm{~h}$ and $58 \pm 5 \%$ at $24 \mathrm{~h}$ ).

IFN- $\gamma$ concentrations started to rise at $4 \mathrm{~h}$ after stimulation and continuously increased until $24 \mathrm{~h}$ (Figure 2B). ATP reduced the rise in IFN- $\gamma$ concentrations at $4 \mathrm{~h}$ $(56 \pm 5 \%), 6 \mathrm{~h}(54 \pm 5 \%)$ and $24 \mathrm{~h}(72 \pm 3 \%)$.

Concentrations of IL-1 $\beta$ increased from $4 \mathrm{~h}$ until $24 \mathrm{~h}$ after stimulation (Figure $2 \mathrm{C}$ ). Again, pretreatment with ATP caused a suppression of the increased IL-1 $\beta$ concentrations at $6 \mathrm{~h}(26 \pm 4 \%)$ and $24 \mathrm{~h}(18 \pm 4 \%)$.

As shown in figure 2D, LPS-PHA stimulation induced a continuous increase of IL-8 concentrations from 2-24 $\mathrm{h}$ after stimulation. Pre-treatment of blood with ATP increased the induced IL-8 concentrations at all time-points (23 $\pm 2 \%$ at $2 \mathrm{~h}, 29 \pm$ $3 \%$ at $4 \mathrm{~h}, 20 \pm 5 \%$ at $6 \mathrm{~h}$ and $11 \pm 2 \%$ at $24 \mathrm{~h}$ ).

The concentrations of IL-10 were increased from 4-24 $\mathrm{h}$ after, with a sharp rise between 6 and $24 \mathrm{~h}$ (Figure 2E). ATP further increased the induced IL-10 concentrations at $4 \mathrm{~h}(29 \pm 3 \%), 6 \mathrm{~h}(22 \pm 2 \%)$ and $24 \mathrm{~h}(55 \pm 4 \%)$. As shown in figure $2 \mathrm{~F}$, the activation of $\mathrm{NF} \kappa \mathrm{B}$ increased from 2-24 $\mathrm{h}$ after LPS-PHA challenge in human blood. Pre-treatment with ATP attenuated this NFKB activation at $2 \mathrm{~h}$ only $(18 \pm 3 \%)$.

\section{Effects of ATP metabolites on inflammatory markers at different time-points after LPS-PHA stimulation}

As shown in table 1, ADP and AMP significantly inhibited the LPS-PHA-induced rise in TNF- $\alpha$ concentrations at 4, 6 and $24 \mathrm{~h}$. Inosine caused an increase in the LPSPHA-induced TNF- $\alpha$ concentration, which was only significant at $24 \mathrm{~h}$. Adenosine, hypoxanthine and uric acid showed no effect on the LPS-PHA-induced TNF- $\alpha$ levels. The LPS-PHA-induced rise in IFN- $\gamma$ concentrations was significantly decreased by ADP, AMP and adenosine. ADP and AMP showed this effect at 4, 6 and $24 \mathrm{~h}$ and adenosine only at 6 and $24 \mathrm{~h}$. Inosine, hypoxanthine and uric acid showed no effect on LPS-PHA-induced IFN- $\gamma$ release. ADP increased the LPSPHA-induced IL-1 $\beta$ release at 6 and $24 \mathrm{~h}$ and AMP and hypoxanthine at $24 \mathrm{~h}$. Adenosine, inosine and uric acid showed no significant effect on the induced IL-1 $\beta$ concentrations. The LPS-PHA-induced rise in IL-8 levels was significantly increased by ADP and AMP at 2, 4, 6 and $24 \mathrm{~h}$. Adenosine, inosine, hypoxanthine and uric acid showed no effect on IL-8. The LPS-PHA-induced rise in IL-10 concentrations were only significantly increased by ADP at $24 \mathrm{~h}$. Hypoxanthine, adenosine and inosine significantly decreased the stimulation-induced rise in IL-10 concentrations at $24 \mathrm{~h}$. AMP and uric acid showed no effect on IL-10 concentrations. 
Table 1: Effect of ATP metabolites $(300 \mu \mathrm{M})$ on cytokine release in LPS-PHA-stimulated blood.

\begin{tabular}{|c|c|c|c|c|c|}
\hline TNF- $\alpha(\mathrm{pg} / \mathrm{ml})$ & $\mathbf{O h}$ & $2 \mathrm{~h}$ & $4 \mathrm{~h}$ & $6 \mathrm{~h}$ & $24 \mathrm{~h}$ \\
\hline Medium & $1.47(0.1)$ & $614(65)$ & $5001(703)$ & 9744 (1431) & $5181(1490)$ \\
\hline ADP & $1.40(0.06)$ & $622(86)$ & $3169(535) *$ & $5696(810) *$ & $2879(958) *$ \\
\hline AMP & $2.00(0.5)$ & $531(48)$ & $2873(502) *$ & $5288(719) *$ & $2786(1028) *$ \\
\hline Adenosine & $1.43(0.9)$ & $546(39)$ & $5603(868)$ & $10633(1892)$ & $5726(1454)$ \\
\hline Inosine & $1.48(0.1)$ & $664(39)$ & $6317(1012)$ & $10789(2460)$ & $6115(1667) *$ \\
\hline hypoxanthine & $1.51(0.09)$ & $690(61)$ & 5914 (969) & 8983 (1551) & $5210(1464)$ \\
\hline Uric acid & $1.4(0.14)$ & $599(39)$ & 4677 (729) & $8417(1330)$ & $4952(965)$ \\
\hline IFN- $\gamma(\mathrm{pg} / \mathrm{ml})$ & $\mathrm{Oh}$ & $2 \mathrm{~h}$ & $4 \mathrm{~h}$ & $6 \mathrm{~h}$ & $24 \mathrm{~h}$ \\
\hline Medium & $2.07(0.25)$ & $2.02(0.13)$ & $97(35)$ & 307 (83) & $3687(1530)$ \\
\hline ADP & $1.74(0.09)$ & $2.1(0.15)$ & 49 (19)* & $143(42) *$ & $1190(528) *$ \\
\hline AMP & $1.82(0.13)$ & $1.94(0.1)$ & $54(22) *$ & $147(44) *$ & 1515 (769)* \\
\hline Adenosine & $1.8(0.14)$ & $2.12(0.15)$ & $92(37)$ & $232(69) *$ & $2020(805) *$ \\
\hline Inosine & $1.74(0.1)$ & $1.99(0.13)$ & $99(38)$ & $303(85)$ & 3167 (85) \\
\hline Hypoxanthine & $1.8(0.12)$ & $2.05(0.11)$ & $78(24)$ & $227(56)$ & 3107 (1267) \\
\hline Uric acid & $1.73(0.12)$ & $1.99(0.14)$ & $87(32)$ & $261(73)$ & $2942(1298)$ \\
\hline $\mathrm{IL}-1 \beta(\mathrm{pg} / \mathrm{ml})$ & $\mathrm{Oh}$ & $2 \mathrm{~h}$ & $4 \mathrm{~h}$ & $6 \mathrm{~h}$ & $24 \mathrm{~h}$ \\
\hline Medium & $2.85(0.89)$ & $1.33(0.17)$ & $325(50)$ & $1271(360)$ & 1774 (279) \\
\hline ADP & $2.80(0.85)$ & $1.68(0.22)$ & $308(48)$ & $1452(362) *$ & $2897(594) *$ \\
\hline AMP & $2.76(0.75)$ & $1.34(0.09)$ & $250(31)$ & $1090(263)$ & $2327(474) *$ \\
\hline Adenosine & $2.88(0.89)$ & $1.45(0.15)$ & $300(47)$ & $1387(875)$ & $2980(1453)$ \\
\hline Inosine & $2.97(0.85)$ & $1.29(0.1)$ & $330(75)$ & $1213(343)$ & 2193 (359) \\
\hline Hypoxanthine & $8.1(5.02)$ & $1.29(0.11)$ & $344(49)$ & $1172(326)$ & 2197 (327)* \\
\hline Uric acid & $2.33(0.65)$ & $1.24(0.1)$ & $286(36)$ & $1089(236)$ & $1645(180)$ \\
\hline IL-8 (pg/ml) & $\mathbf{O h}$ & $2 \mathrm{~h}$ & $4 \mathrm{~h}$ & $6 \mathrm{~h}$ & $24 \mathrm{~h}$ \\
\hline Medium & $4.19(1.39)$ & $480(87)$ & 2255 (309) & $4331(297)$ & $10772(262)$ \\
\hline ADP & $4.13(0.83)$ & 824 (105)* & $3429(383) *$ & 4963 (165)* & $12574(213) *$ \\
\hline AMP & $3.96(0.98)$ & $577(87) *$ & $3156(432) *$ & $5094(154) *$ & $11857(254) *$ \\
\hline Adenosine & $3.1(0.43)$ & $446(56)$ & 2452 (395) & $4650(292)$ & $10315(286)$ \\
\hline Inosine & $3.38(0.44)$ & $526(69)$ & $2572(386)$ & $4532(222)$ & $10577(312)$ \\
\hline Hypoxanthine & $3.49(0.62)$ & $581(83)$ & $2833(468)$ & 4361 (259) & $10710(329)$ \\
\hline Uric acid & $3.17(0.45)$ & $530(70)$ & 2257 (301) & $4293(261)$ & 10467 (311) \\
\hline IL-10 (pg/ml) & $\mathbf{O h}$ & $2 \mathrm{~h}$ & $4 \mathrm{~h}$ & $6 \mathrm{~h}$ & $24 \mathrm{~h}$ \\
\hline Medium & $1.044(0.07)$ & $1.088(0.09)$ & $4.99(0.66)$ & $30.99(3)$ & $1966(257)$ \\
\hline ADP & $0.95(0.01)$ & $1.225(0.10)$ & $4.92(0.65)$ & $34.75(7)$ & $2566(143) *$ \\
\hline AMP & $0.98(0.06)$ & $1.39(0.16)$ & $4.65(0.74)$ & $32(5)$ & $1905(227)$ \\
\hline Adenosine & $1.03(0.06)$ & $1.30(0.13)$ & $3.62(0.25)$ & $27.77(4)$ & $1437(172) *$ \\
\hline Inosine & $0.93(0.04)$ & $1.09(0.07)$ & $3.93(0.43)$ & $28.19(4)$ & $1585(220) *$ \\
\hline Hypoxanthine & $0.93(0.09)$ & $1.069(0.05)$ & $3.88(0.39)$ & $28.45(5)$ & $1517(237) *$ \\
\hline Uric acid & $0.87(0.03)$ & $1.08(0.04)$ & $3.90(0.37)$ & $30.78(5)$ & $1608(234)$ \\
\hline
\end{tabular}


Data are shown as mean (SEM) in six subjects $\left({ }^{*} \mathrm{P}<0.05\right.$ compared to cytokine release in the presence of medium (control condition)).

\section{Discussion}

We recently showed that the natural compound ATP is able to modulate cytokine release in LPS-PHA-stimulated blood by simultaneously inhibiting TNF- $\alpha$ release via activation of the $P 2 Y_{11}$ receptor and increasing IL-10 release by activating the $P 2 Y_{12}$ receptor [6, 7]. These data were observed $24 \mathrm{~h}$ after LPS-PHA stimulation of blood. So far, it was unclear whether ATP also exerts these immunomodulatory effects at earlier time-points, and if ATP is able to modulate the release of other cytokines, besides TNF- $\alpha$ and IL-10.

ATP in the extracellular compartment is known to be metabolized by various ectoenzymes and xanthine oxidase [5]. Several groups have shown that ATP, when added to whole blood, was completely degraded within 30 min $[18,19]$. Our results indicate that the complete degradation of ATP, added to LPS-PHA-stimulated blood, takes more than 6 hours. This discrepancy can be explained by the fact that we diluted the blood four times with medium, thus lowering ecto-enzyme concentrations. There was no difference in the degradation profile of ATP when saline instead of medium was used, indicating that the medium as such did not interfere with the degradation of ATP. The strong hypoxanthine release observed at $24 \mathrm{~h}$ was not due to the presence of LPS-PHA, because the degradation profile of ATP was the same in the absence of LPS-PHA.

We then investigated the time-dependent effects of ATP on several inflammatory markers at different time-points after LPS-PHA stimulation. The pro-inflammatory cytokines TNF- $\alpha$, IFN- $\gamma$ and IL-1 $\beta$ are known to be primarily involved in promoting inflammatory processes [20-23]. The chemokine IL-8 is responsible for inducing the directed migration of cells to a site of inflammation (chemotaxis) and has an important role in regulating the acute inflammatory response [24]. Increased plasma levels of IL-8 may exert anti-inflammatory effects since it has been demonstrated that elevated levels in the circulation reduce recruitment of neutrophils [25]. IL-10 is a potent anti-inflammatory cytokine that inhibits the synthesis of many inflammatory proteins, including cytokines like TNF- $\alpha$ and chemokines and is among others produced by activated T cells [21]. Our study shows that TNF- $\alpha$, IL-8 and IL-1 $\beta$ are released early and gradually after stimulation of blood by LPS-PHA, which is consistent with their role in acute inflammatory processes. IFN- $\gamma$ release appeared to predominate at later time-points, possibly reflecting its role in amplifying inflammatory processes. Finally, the predominant IL-10 release at the latest timepoint $(24 \mathrm{~h})$ may reflect its role in the resolution of inflammatory processes as a natural feedback mechanism. Our data show that ATP attenuates the stimulationinduced rise in concentrations of TNF- $\alpha$, IFN- $\gamma$ and IL-1 $1 \beta$, but increases the 
stimulation-induced rise in IL-8 and IL-10 concentrations. In addition, our data indicate that ATP already exerts these anti-inflammatory effects within $2 \mathrm{~h}$ for TNF- $\alpha$ and IL-8 and within $4 \mathrm{~h}$ for IFN- $\gamma, \mathrm{IL}-1 \beta$ and IL-10, and that these effects persist until $24 \mathrm{~h}$ for all cytokines.

It is well recognized that metabolites of ATP can also exert powerful modulatory effects on the immune system. We therefore tested the time-dependent effects of several metabolites of ATP on cytokine release in stimulated blood. Our data show that ADP has some similar effects as ATP: it inhibits LPS-PHA-induced TNF- $\alpha$ and IFN- $\gamma$ and stimulates IL-8 and IL-10 production. Moreover, in contrast to ATP, ADP stimulated LPS-PHA-induced IL-1 $\beta$ production. Among all the tested metabolites, ADP is the only metabolite, which showed, just as ATP, a stimulatory effect on LPSPHA-induced IL-10. This finding corroborates and expands on our recent report [7], which showed that the stimulatory effect of ATP on IL-10 release observed $24 \mathrm{~h}$ after stimulation, when all ATP is metabolized, was regulated via activation of the $\mathrm{P}_{2} \mathrm{Y}_{12}$ receptor, a receptor activated by ADP [10, 12]. AMP, similar to ATP, inhibited LPS-PHA-induced TNF- $\alpha$ and IFN- $\gamma$ production and stimulated LPS-PHA-induced IL-8 production. But in contrast to ATP, AMP stimulated LPS-PHA-induced IL-1 $\beta$ and had no effect on IL-10 production.

ADP and AMP were the only metabolites showing, just like ATP, an attenuation of the stimulation-induced rise in TNF- $\alpha$ concentration. This does not necessarily indicate that the earlier observed inhibitory effect of ATP on TNF- $\alpha$ release $24 \mathrm{~h}$ after stimulation [6], when all ATP is metabolized, is due to these metabolites. In fact, we earlier demonstrated that the inhibitory effect of ATP on TNF- $\alpha$ release observed $24 \mathrm{~h}$ after stimulation was mediated by the $\mathrm{P}_{2} \mathrm{Y}_{11}$ receptor [7], which is known to be activated only by ATP as a natural occurring agonist [8, 10, 11]. Moreover, we showed earlier that adenosine 5'-O-(3-thiotriphosphate) (ATP $\gamma \mathrm{S}$ ), a stable analogue of ATP, also inhibited the TNF- $\alpha$ release $24 \mathrm{~h}$ after stimulation [6, 7].

The nucleoside adenosine is a well known immunomodulatory agent and has been shown to inhibit deleterious immune-mediated processes, including the release of pro-inflammatory cytokines from different types of stimulated cells [4, 26-29]. Surprisingly, in our study, adenosine showed no effect on LPS-PHA-induced TNF- $\alpha$, $\mathrm{IL}-1 \beta$ and IL-8 concentrations, but it inhibited IFN- $\gamma$ and IL-10 release. Similar inhibitory effects of adenosine on IL-10 and IFN- $\gamma$ release were shown earlier in different cell types by several groups. Thus, Erdmann at al. [30] showed that the IL10 secretion, induced by a mixed population of murine effector CD4 ${ }^{+} \mathrm{Th}_{2}$ and CD8 ${ }^{+}$ $\mathrm{Th}_{2}$ cells, was inhibited through $\mathrm{A}_{2 \mathrm{~A}}$ receptor stimulation. Furthermore, adenosine inhibited the production of IFN- $\gamma$ in immuno-stimulated mature human dendritic cells [31]. Inosine, which is formed by the breakdown of adenosine by adenosine deaminase, is also known to have potent anti-inflammatory effects by inhibiting the release of pro-inflammatory cytokines and chemokines by different stimulated cell types [32-34]. In our stimulated blood model, inosine showed no effect on LPS-PHA- 
induced IFN- $\gamma$, IL-1 $\beta$ and IL-8 concentrations, but it showed an inhibitory effect on TNF- $\alpha$ and IL-10.

Very limited information is available on the pharmacological effects of hypoxanthine, the purine base that is cleaved off from inosine. In our study, hypoxanthine showed no effect on LPS-PHA-induced TNF- $\alpha$, IFN- $\gamma$ and IL-8 concentrations but it significantly stimulated the rise in IL-1 $\beta$ concentrations and decreased the rise in IL10 concentrations after LPS-PHA stimulation. The fact that hypoxanthine showed no effect on TNF- $\alpha$ release and an opposite effect on IL-10 release, compared to ATP, indicates that the release of hypoxanthine observed $24 \mathrm{~h}$ after LPS-PHA stimulation is not responsible for the anti-inflammatory effects of ATP observed $24 \mathrm{~h}$ after stimulation, when all ATP is metabolized.

Production of cytokines and chemokines is essential in immunity and involves the activation of several transcription factors, including NFKB [15]. In the resting state, $N F_{\kappa B}$ is present in the cytoplasm of the cell through its tight association with the inhibitory protein $I_{\kappa} B$ [35]. Upon cell stimulation, such as LPS, $I_{\kappa} B$ is phosphorylated and degraded, followed by translocation of $\mathrm{NF} \kappa \mathrm{B}$ into the nucleus to regulate transcriptional activation of a host of cytokine genes and subsequent release of cytokines, including TNF- $\alpha, \mathrm{IL}-6, \mathrm{IL}-1 \beta$ and IL-8 $[36,37]$. Our data show that NF $\mathrm{B}$ is activated in a time-dependent fashion (at 2 until $24 \mathrm{~h}$ ) after LPS-PHA stimulation in blood. Moreover, ATP was able to down-regulate the stimulation-induced NFKB activation at $2 \mathrm{~h}$ only, which indicates an early inhibitory effect of ATP on NFkB. The modest inhibitory effect of ATP on NFкB activation could suggest that other transcription factors or other intracellular pathways are also involved in the observed effects of ATP on cytokine production. Another possibility is that NFKB has already reached it maximum activation between 0 and $2 \mathrm{~h}$ after stimulation.

In conclusion, in the present study, we have further characterized the used LPSPHA-stimulated blood model. In this model, ATP is slowly broken down and almost completely degraded after $6 \mathrm{~h}$. During that time, ADP, AMP and hypoxanthine are formed, with a high release of hypoxanthine at $24 \mathrm{~h}$. ATP inhibits the release of TNF- $\alpha$, IFN- $\gamma$ and IL-1 $\beta$, but stimulates the release of IL-10 and IL-8 after LPS-PHA stimulation of blood. Our results demonstrate that ATP is able to modulate a variety of cytokines in stimulated blood; moreover, these immunomodulatory effects of ATP are rapid (at 2, 4 and $6 \mathrm{~h}$ after LPS-PHA stimulation) and persist until $24 \mathrm{~h}$. 


\section{References}

1 Burnstock G. and Knight G.E. Cellular distribution and functions of P2 receptor subtypes in different systems. Int Rev Cytol 2004; 240: 31-304.

2 Ralevic V. and Burnstock G. Receptors for purines and pyrimidines. Pharmacol Rev 1998; 50: 413-492.

3 Abbracchio M.P. and Burnstock G. Purinoceptors: are there families of P2X and P2Y purinoceptors? Pharmacol Ther 1994; 64: 445-475.

4 Bours M.J., Swennen E.L., Di Virgilio F., Cronstein B.N. and Dagnelie P.C. Adenosine 5'triphosphate and adenosine as endogenous signaling molecules in immunity and inflammation. Pharmacol Ther 2006.

5 Zimmermann $\mathrm{H}$. Extracellular metabolism of ATP and other nucleotides. Naunyn Schmiedebergs Arch Pharmacol 2000; 362: 299-309.

6 Swennen E.L., Bast A. and Dagnelie P.C. Immunoregulatory effects of adenosine 5'triphosphate on cytokine release from stimulated whole blood. Eur J Immunol 2005; 35: 852858.

7 Swennen E.L., Bast A. and Dagnelie P.C. Purinergic receptors involved in the immunomodulatory effects of ATP in human blood. Biochem Biophys Res Commun 2006; 348: 1194-1199.

8 Communi D., Govaerts C., Parmentier M. and Boeynaems J.M. Cloning of a human purinergic P2Y receptor coupled to phospholipase C and adenylyl cyclase. J Biol Chem 1997; 272: 31969-31973.

9 von Kugelgen I. and Wetter A. Molecular pharmacology of P2Y-receptors. Naunyn Schmiedebergs Arch Pharmacol 2000; 362: 310-323.

10 Von Kugelgen I. Pharmacological profiles of cloned mammalian P2Y-receptor subtypes. Pharmacology \& Therapeutics 2005; 110: 415-432.

11 Communi D., Robaye B. and Boeynaems J.M. Pharmacological characterization of the human P2Y11 receptor. Br J Pharmacol 1999; 128: 1199-1206.

12 Communi D., Gonzalez N.S., Detheux M., Brezillon S., Lannoy V., Parmentier M. and Boeynaems J.M. Identification of a novel human ADP receptor coupled to G(i). J Biol Chem 2001; 276: 41479-41485.

13 Moynagh P.N. The NF-kappaB pathway. J Cell Sci 2005; 118: 4589-4592.

14 Bonizzi G. and Karin M. The two NF-kappaB activation pathways and their role in innate and adaptive immunity. Trends Immunol 2004; 25: 280-288.

15 Barnes P.J. and Karin M. Nuclear factor-kappaB: a pivotal transcription factor in chronic inflammatory diseases. N Engl J Med 1997; 336: 1066-1071.

16 Hofmann M.A., Schiekofer S., Isermann B., Kanitz M., Henkels M., Joswig M., Treusch A., Morcos M., Weiss T., Borcea V., Abdel Khalek A.K., Amiral J., Tritschler H., Ritz E., Wahl P., Ziegler R., Bierhaus A. and Nawroth P.P. Peripheral blood mononuclear cells isolated from patients with diabetic nephropathy show increased activation of the oxidative-stress sensitive transcription factor NF-kappaB. Diabetologia 1999; 42: 222-232.

17 Schweinsberg P.D. and Loo T.L. Simultaneous analysis of ATP, ADP, AMP, and other purines in human erythrocytes by high-performance liquid chromatography. $J$ Chromatogr 1980; 181 : 103-107.

18 Heptinstall S., Johnson A., Glenn J.R. and White A.E. Adenine nucleotide metabolism in human blood--important roles for leukocytes and erythrocytes. $J$ Thromb Haemost 2005; 3: 2331-2339.

19 Coade S.B. and Pearson J.D. Metabolism of adenine nucleotides in human blood. Circ Res 1989; 65: 531-537. 
20 Adam J.K., Odhav B. and Bhoola K.D. Immune responses in cancer. Pharmacol Ther 2003; 99: 113-132.

21 Curfs J.H., Meis J.F. and Hoogkamp-Korstanje J.A. A primer on cytokines: sources, receptors, effects, and inducers. Clin Microbiol Rev 1997; 10: 742-780.

22 Yamagata T. and Ichinose M. Agents against cytokine synthesis or receptors. Eur $J$ Pharmacol 2006; 533: 289-301.

23 Dinarello C.A. Interleukin-1 beta. Crit Care Med 2005; 33: S460-462.

24 Remick D.G. Interleukin-8. Crit Care Med 2005; 33: S466-467.

25 Mehrad B., Strieter R.M., Moore T.A., Tsai W.C., Lira S.A. and Standiford T.J. CXC chemokine receptor-2 ligands are necessary components of neutrophil-mediated host defense in invasive pulmonary aspergillosis. J Immunol 1999; 163: 6086-6094.

26 Hasko G. and Cronstein B.N. Adenosine: an endogenous regulator of innate immunity. Trends Immunol 2004; 25: 33-39.

27 Sitkovsky M.V. Use of the $\mathrm{A}(2 \mathrm{~A})$ adenosine receptor as a physiological immunosuppressor and to engineer inflammation in vivo. Biochem Pharmacol 2003; 65: 493-501.

28 Zhang J.G., Hepburn L., Cruz G., Borman R.A. and Clark K.L. The role of adenosine A2A and $\mathrm{A} 2 \mathrm{~B}$ receptors in the regulation of TNF-alpha production by human monocytes. Biochem Pharmacol 2005; 69: 883-889.

29 Bouma M.G., Stad R.K., van den Wildenberg F.A. and Buurman W.A. Differential regulatory effects of adenosine on cytokine release by activated human monocytes. $J$ Immunol 1994; 153: 4159-4168.

30 Erdmann A.A., Gao Z.G., Jung U., Foley J., Borenstein T., Jacobson K.A. and Fowler D.H. Activation of Th1 and Tc1 cell adenosine A2A receptors directly inhibits IL-2 secretion in vitro and IL-2-driven expansion in vivo. Blood 2005; 105: 4707-4714.

31 Schnurr M., Toy T., Shin A., Hartmann G., Rothenfusser S., Soellner J., Davis I.D., Cebon J. and Maraskovsky E. Role of adenosine receptors in regulating chemotaxis and cytokine production of plasmacytoid dendritic cells. Blood 2004; 103: 1391-1397.

32 Mabley J.G., Pacher P., Liaudet L., Soriano F.G., Hasko G., Marton A., Szabo C. and Salzman A.L. Inosine reduces inflammation and improves survival in a murine model of colitis. Am J Physiol Gastrointest Liver Physiol 2003; 284: G138-144.

33 Hasko G., Kuhel D.G., Nemeth Z.H., Mabley J.G., Stachlewitz R.F., Virag L., Lohinai Z., Southan G.J., Salzman A.L. and Szabo C. Inosine inhibits inflammatory cytokine production by a posttranscriptional mechanism and protects against endotoxin-induced shock. $J$ Immunol 2000; 164: 1013-1019.

34 Marton A., Pacher P., Murthy K.G., Nemeth Z.H., Hasko G. and Szabo C. Anti-inflammatory effects of inosine in human monocytes, neutrophils and epithelial cells in vitro. Int $\mathrm{J}$ Mol Med 2001; 8: 617-621.

35 Karin M. and Ben Neriah Y. Phosphorylation meets ubiquitination: the control of NF-[kappa]B activity. Annu Rev Immunol 2000; 18: 621-663.

36 Lazaron V. and Dunn D.L. Molecular biology of endotoxin antagonism. World J Surg 2002; 26: 790-798.

37 Cadenas S. and Cadenas A.M. Fighting the stranger-antioxidant protection against endotoxin toxicity. Toxicology 2002; 180: 45-63. 
Radioprotective effects of ATP in human blood ex vivo

\author{
Els L.R. Swennen \\ Twan van den Beucken \\ Pieter C. Dagnelie
}

Aalt Bast

Submitted 


\begin{abstract}
Damage to healthy tissue is a major disadvantage of radiotherapy treatment of cancer patients, leading to several side effects and complications. Radiationinduced release of pro-inflammatory cytokines is thought to be partially responsible for the radiation-associated complications. The aim of the present study was to investigate the protective effects of the natural compound adenosine 5'-triphosphate (ATP) on markers of oxidative stress, radiation-induced inflammation and DNA damage in irradiated blood ex vivo. ATP inhibited radiation-induced tumour necrosis factor-alpha $(T N F-\alpha)$ release and increased interleukin (IL)-10 release. The inhibitory effect of ATP on TNF- $\alpha$ release was completely reversed by adenosine 5'O-thiomonophosphate (5'-AMPS), indicating a P2Y 11 mediated effect. Furthermore, ATP attenuated radiation-induced DNA damage at 10 min (immediate), 3 and $6 \mathrm{~h}$ after irradiation. Pretreatment of blood with ATP protected against irradiationinduced glutathione (GSH) depletion. Our study indicates that ATP administration alleviates radiation-toxicity to blood cells, mainly by inhibiting radiation-induced inflammation and DNA damage.
\end{abstract}




\section{Introduction}

Radiation is one of the main options for treatment of cancer. Damage to healthy tissue is a major factor limiting the radiation dose applied in cancer treatment. This is especially the case for highly radiosensitive organs, such as the lungs [1, 2]. Pneumonitis as an early pathologic change, and pulmonary fibrosis as a late pathologic change are common toxicities observed after radiotherapy for lung cancer [3, 4]. Although the underlying mechanisms responsible for radiationassociated complications remain unclear, radiation-induced release of proinflammatory cytokines is likely to be involved [4,5]. The cytokine network is activated shortly after irradiation and this may account at least partly for the acute (pneumonitis), as well as the late (fibrosis) effects of radiation-induced damage [4].

The importance of protection of healthy tissue against radiation injury has triggered the search for radioprotective compounds. However, even though many compounds tested showed good radioprotection in in vitro studies, most failed in in vivo application mainly because of their acute toxicity [6].

We earlier reported that the natural compound adenosine 5'-triphosphate (ATP) has anti-inflammatory properties in lipopolysaccharide (LPS)-phytohemagglutinin (PHA) stimulated human blood, as shown by inhibition of tumour necrosis factor- $\alpha$ (TNF- $\alpha$ ) and stimulation of interleukin (IL)-10 release [7]; these effects were attributed to activation of the $P 2 Y_{11}$ and $P 2 Y_{12}$ receptors, respectively [8]. The present study aimed to examine the protective effects of ATP against radiation-induced injury in human blood ex vivo. For this purpose, we investigated the effects of ATP on cytokine release, nuclear factor kappaB $(\mathrm{NF} \kappa \mathrm{B})$ activation, DNA damage and oxidative stress markers at different time-points after irradiation of blood.

\section{Material and methods}

\section{Chemicals}

Human TNF- $\alpha$ and human IL-10 high sensitivity enzyme linked immune sorbent assay (ELISA) kits were obtained from R\&D systems (Quantikine HS, Minneapolis, United States of America). RPMI 1640 medium containing L-glutamine was obtained form Gibco, UK. ATP was purchased from Calbiochem, USA. Adenosine 5'-Othiomonophosphate (5'-AMPS) was purchased from Sigma Chemical Co, St. Louis, USA. PSB-0413 (AR-C67085MX, 2-propylthioadenosine-5'-adenylic acid (1,1dichloro-1-phosphonomethyl-1-phosphonyl) anhydride) [9] was a kind gift from Prof. Dr. C.E. Müller (Pharmaceutical Chemistry, University of Bonn). All other chemicals were of analytical grade. 


\section{Irradiation}

Blood from eight healthy volunteers (age range 25-35 years; 4 women and 4 men) was incubated with medium (control) or ATP $(300 \mu \mathrm{M})$. Following a $30 \mathrm{~min}$ incubation period at $37^{\circ} \mathrm{C}$, each blood sample was divided into two parts: one was exposed to $16 \mathrm{~Gy}$ (irradiated sample); the other was not exposed to irradiation. The effects of receptor antagonists were investigated by pre-incubating blood for $15 \mathrm{~min}$ with antagonists prior to the addition of medium or ATP. Antagonists were prepared in external stock solutions (dissolved either in RPMI 1640 medium or dimethyl sulfoxide (DMSO)), which were stored at $-20^{\circ} \mathrm{C}$ and diluted immediately before use. Irradiations were performed with a Philips MCN 225 industrial x-ray tube (Philips, W Germany) operated at $225 \mathrm{kV}$ and $10 \mathrm{~mA}$ delivering a dose-rate of $0.85 \mathrm{~Gy} / \mathrm{min}$.

\section{Blood sampling}

At different time-points after irradiation whole blood samples were collected and frozen for analysis of glutathione-related enzymes. For the analysis of reduced glutathione (GSH) and oxidized glutathione (GSSG) blood samples were treated with $1.3 \%$ sulphosalicilic acid (SSA) in $100 \mathrm{mM} \mathrm{HCl}$ to preserve the samples. Because of the instability of GSH in blood, GSH and GSSG levels were measured only $10 \mathrm{~min}$ (immediate) after irradiation. Plasma was collected by centrifugation (3500 rpm, $10 \mathrm{~min}$ at $4^{\circ} \mathrm{C}$ ) and stored at $-80^{\circ} \mathrm{C}$ for cytokines, Trolox equivalent antioxidant capacity (TEAC) and malondialdehyde (MDA) analysis. To isolate white blood cells (WBC), the erythrocyte pellet was washed several times with erythrocyte lysis buffer (containing $\mathrm{NH}_{4} \mathrm{Cl}, \mathrm{KHCO}_{3}$ and EDTA) and placed on ice to lyse the erythrocytes. At the end, the pellet was washed with PBS and finally, the cells were resuspended in $1 \mathrm{ml}$ cold PBS. For the analysis of DNA damage, $10 \mu \mathrm{l}$ of the cell suspension was mixed with $90 \mu \mathrm{l}$ of $1 \%$ low-melting-point agarose of $37^{\circ} \mathrm{C}$ and layered onto agarose-coated (1.5\% agarose in PBS) microscope slides. The slides were covered with a coverslip and kept at $4^{\circ} \mathrm{C}$ for $5 \mathrm{~min}$ to allow the low-meltingpoint agarose to solidify. Then, the coverslips were removed and the slides were stored in a jar containing cold lysing solution $(2.5 \mathrm{M} \mathrm{NaCl}, 100 \mathrm{mM} \mathrm{Na}$ ethylenediaminetetraacetic acid, $10 \mathrm{mM}$ Tris [pH 10], $1 \%$ Triton-X-100 and 10\% DMSO). The remaining WBC solution was centrifuged and the pellet was used to prepare nuclear extracts for NFKB determination. For this purpose, the WBC pellets were lysed using an ice-cold lysis buffer as described by Hofmann et al. [10] and centrifuged at $15000 \mathrm{rpm}$ for $1 \mathrm{~min}$ at $4^{\circ} \mathrm{C}$. The nuclear pellets were resuspended in ice-cold extraction buffer as described by Hofmann et al. [10]. After 20 min at $4^{\circ} \mathrm{C}$, the nuclear lysates were centrifuged at $15000 \mathrm{rpm}$ for $2 \mathrm{~min}$ at $4^{\circ} \mathrm{C}$ and the supernatants, containing the nuclear proteins, were immediately collected and stored at $-80^{\circ} \mathrm{C}$ until analysis of $\mathrm{NF} \kappa \mathrm{B}$ and protein concentration. 


\section{Cytokine measurement via ELISA}

All cytokines were quantified using R\&D high sensitivity ELISA kits (Quantikine HS, Minneapolis, United States of America) based on appropriate and validated sets of monoclonal antibodies. Assays were performed as described by the manufacturer's instructions.

\section{NFKB and protein measurement}

NFKB concentrations were determined in nuclear extracts, according to the manufacturer's instructions (TransAM NFкB p50 transcription Factor Assay Kit; Active Motif Europe, Rixensart, Belgium), using a protein content of $200-300 \mu \mathrm{g} / \mathrm{ml}$ in the nuclear extracts; protein concentrations were determined using the method of Bradford (Biorad), using bovine serum albumin as a standard.

\section{Comet assay}

As an additional marker of systemic oxidative stress, the comet assay, which is a sensitive technique for analyzing reactive oxygen species (ROS)-induced DNA damage, was used. The comet assay (single-cell gel electrophoresis) was adapted from the method described by Mercken et al. [11] with minor modifications. In short, the prepared slides stored in lysing solution (see preparation as described in blood sampling) were placed in a horizontal electrophoresis unit filled with fresh cold electrophoresis buffer $\left(10 \mathrm{~N} \mathrm{NaOH}, 200 \mathrm{mM} \mathrm{Na}{ }_{2}\right.$ ethylenediaminetetraacetic acid, $\mathrm{pH}$ between 12.5 and 13.5) for $20 \mathrm{~min}$. Electrophoresis was performed for $20 \mathrm{~min}$ at $25 \mathrm{~V}$ and $300 \mathrm{~mA}$. Subsequently, slides were washed gently three times in neutralization buffer $(0.4 \mathrm{M}$ Tris, $\mathrm{pH} 7.5)$ and stored at $4^{\circ} \mathrm{C}$ until further analysis. For microscope analysis, each slide was stained with $50 \mu \mathrm{l}$ of ethidium bromide (20 $\mu \mathrm{g} / \mathrm{ml}$ ). Comet measurements were made by image analysis using a fluorescence microscope and the comet assay III software (perceptive Instruments, Suffolk, UK). DNA damage was measured as tail moment (based on the product of the percentage of DNA in the tail and tail length).

\section{GSH and GSSG}

GSH and GSSG calibrators were prepared freshly and contained the same concentrations of SSA as the samples. GSH levels were determined by measuring the increase in absorbance, caused by the GSH driven reduction of 5',5'-dithiobis-2nitrobenzoic acid (DTNB) during the enzymatic reaction started by adding GSSG reductase, using the recycling method as described by Vandeputte et al. [12]. GSSG was measured by the same protocol as GSH, with the only difference that this assay involves a GSH derivatization by 2-vinylpyridine [12]. 


\section{TEAC and uric acid}

The TEAC value, which gives the capacity of a solution to neutralize the stable $(2,2$ 'azino-bis(3-ethylbenzothiazoline-6-sulfonate) (ABTS) radical, was determined as previously described by Fischer et al. [13] and is expressed as $\mu \mathrm{M}$ trolox equivalents. Uric acid was measured in plasma, deproteinated with a final concentration of $5 \%$ trichloric acid, using a high performance liquid chromatography (HPLC) method described by Lux et al. [14]. The system (Agilent, Palo Alto, CA, USA) consisted of a Hypersil ODS C-18 end-capped column, $125 \times 4 \mathrm{~mm}$, particle size $5 \mu \mathrm{M}$ (Agilent, Palo Alto, CA, USA) with a mobile phase of $0.1 \%$ trifluoric acid in MilliQ. UV detection was performed at $292 \mathrm{~nm}$.

\section{MDA}

The determination of MDA was based on the formation of a colored adduct of MDA with 2-thiobarbituric acid (TBA) using a HPLC method as described previously by Lepage et al. [15].

\section{Glutathione Peroxidase assay (GPx)}

The selenium-dependent GPx activity, with hydrogen peroxide $\left(\mathrm{H}_{2} \mathrm{O}_{2}\right)$ as substrate, was determined by measuring the decrease in absorbance due to the consumption of NADPH [16]. GPx activity was calculated using the molar absorbance coefficient of NADPH.

\section{Glutathione Reductase assay (GR)}

GR activity was determined by measuring the decrease in absorbance caused by the consumption of NADPH in the enzymatic reduction of GSSG to GSH by GR [17]. The activity was calculated using the molar absorbance coefficient of NADPH.

\section{Glutathione-S-Transferase assay (GST)}

GST activity was determined by the GST catalyzed reaction of 1-chloro-2,4dinitrobenzene with GSH, resulting in a yellow colored product, $\mathrm{GSH}$ dinitrobenzene, of which the increase in absorbance was measured [18]. The activity of GST in the samples was calculated using the molar absorbance coefficient of GSH-dinitrobenzene. 


\section{Statistics}

The effect of irradiation compared to baseline (no irradiation) and of ATP on radiation-induced damage compared to irradiation in the absence of ATP was determined using Wilcoxon's signed rank test. Two-tailed $P$ values of 0.05 or less were considered statistically significant. Results are reported as means \pm SEM. For the comet assay, data were expressed as median \pm SEM.

\section{Results}

\section{Effect of ATP on radiation-induced cytokine release}

As shown in figure 1, TNF- $\alpha$ concentrations in non-irradiated blood were stable. TNF- $\alpha$ was induced $3 \mathrm{~h}$ after irradiation exposure and this effect remained at $6 \mathrm{~h}$ after irradiation. In the presence of ATP, the radiation-induced TNF- $\alpha$ release was significantly attenuated by $42 \pm 6 \%$ (mean \pm SEM) at $3 \mathrm{~h}$ after irradiation and by 34 $\pm 8 \%$ at $6 \mathrm{~h}$ after irradiation. The $\mathrm{P}_{2} \mathrm{Y}_{11}$ antagonist 5'-AMPS largely reversed the inhibitory effect of ATP on radiation-induced TNF- $\alpha$ release.

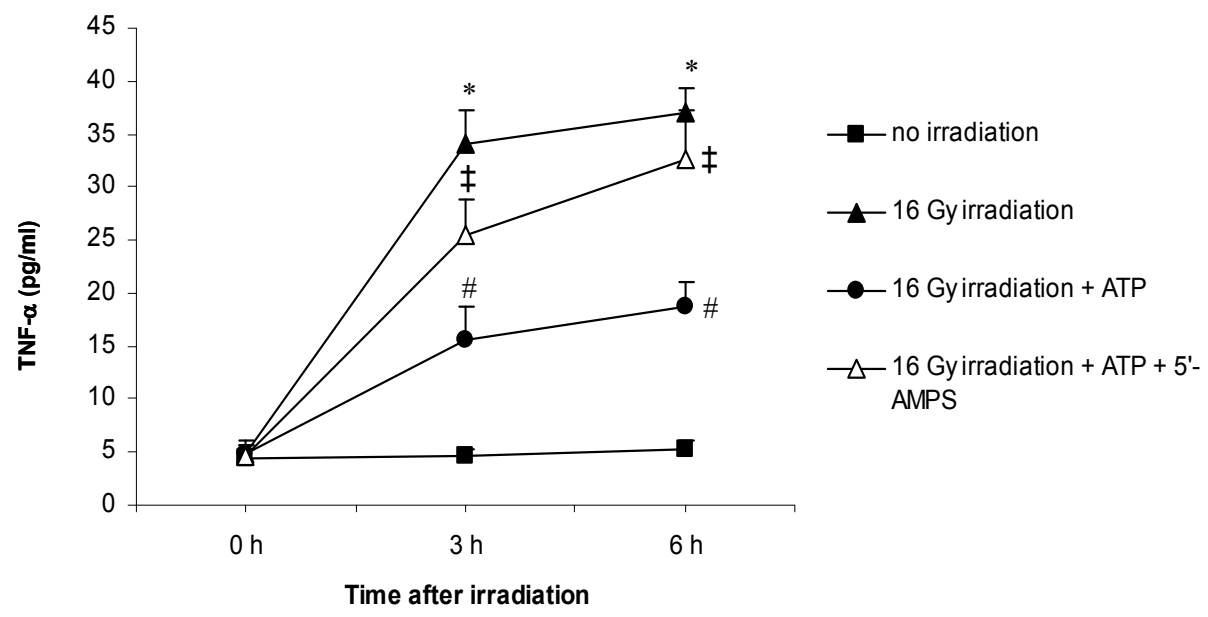

Figure 1: Effect of ATP $(300 \mu \mathrm{M})$ on TNF- $\alpha$ release at different time-points $(0,3$ and $6 \mathrm{~h})$ after irradiation in the absence and presence of the P2Y ${ }_{11}$ receptor antagonist 5'-AMPS $(100 \mu \mathrm{M})$ in human blood. Data are expressed as mean values, with error bars representing SEM. ${ }^{*} \mathrm{P}<0.01$ compared to no irradiation, ${ }^{\sharp} \mathrm{P}<0.05$ compared to irradiation in the absence of $\mathrm{ATP},{ }^{\ddagger} \mathrm{P}<0.05$ compared to irradiation in the presence of ATP. 
The $\mathrm{P}_{2} \mathrm{Y}_{12}$ receptor antagonist PSB-0413 showed no effect on TNF- $\alpha$ release in the presence of ATP (data not shown).

In non-irradiated blood, concentrations of the anti-inflammatory cytokine IL-10 were stable (Figure 2). IL-10 concentrations were slightly, but not significantly ( $P=0.069$ ), increased at $3 \mathrm{~h}$ after irradiation. At $6 \mathrm{~h}$ after irradiation exposure, IL-10 concentrations were significantly increased and in the presence of ATP this radiation-induced IL-10 increase was significantly stimulated by $27 \pm 7 \%$. Both the $\mathrm{P}_{2} \mathrm{Y}_{12}$ receptor antagonist PSB-0413 and the $\mathrm{P}^{2} \mathrm{Y}_{11}$ antagonist 5'-AMPS (data not shown) did not block the ATP-induced IL-10 stimulation. Both 5'-AMPS and PSB0413 alone and in the absence of irradiation did not have an effect on TNF- $\alpha$ and IL10 release (data not shown).

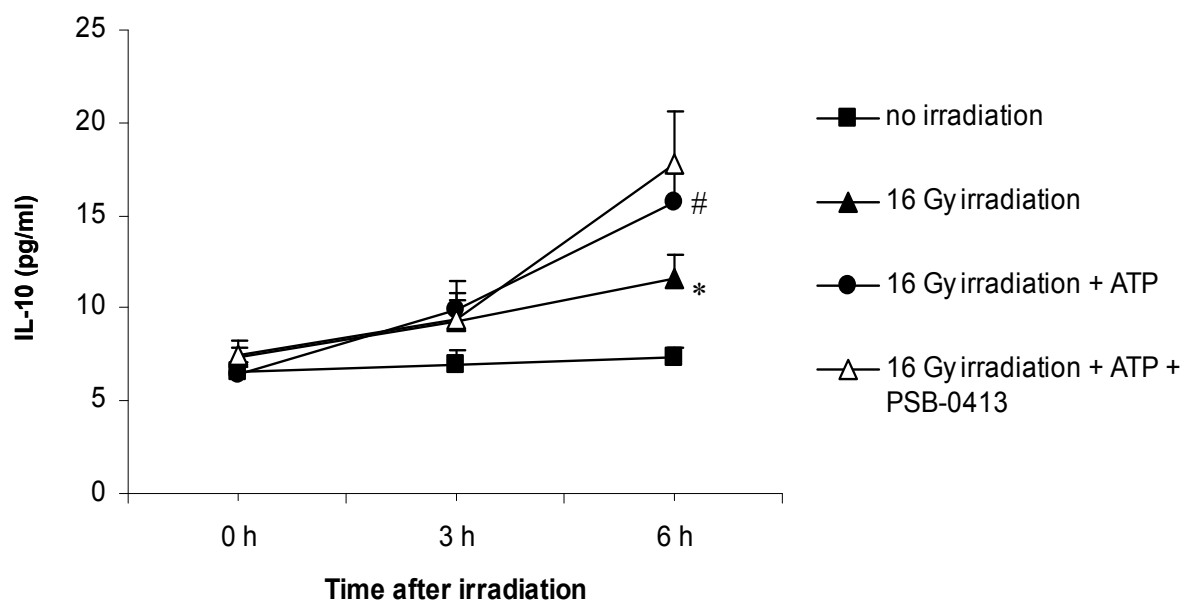

Figure 2: Effect of ATP $(300 \mu \mathrm{M})$ on IL-10 release at different time-points $(0,3$ and $6 \mathrm{~h})$ after irradiation in the absence and presence of the $\mathrm{P}_{2} \mathrm{Y}_{12}$ receptor antagonist PSB-0413 (25 nM) in human blood. Data are expressed as mean values, with error bars representing SEM. ${ }^{*} \mathrm{P}<0.05$ compared to no irradiation, ${ }^{\#}<0.05$ compared to irradiation in the absence of ATP.

\section{Effect of ATP on radiation-induced NFKB activation}

As shown in figure 3 , the transcription factor $N F_{\kappa B}$ was significantly increased $3 \mathrm{~h}$ after irradiation exposure; this effect was no longer observed $6 \mathrm{~h}$ after irradiation exposure. In the presence of ATP, the irradiation-induced NFKB activation was not significantly attenuated compared to the control condition (no ATP). In nonirradiated blood, no NFKB activation was observed at any time-point. 


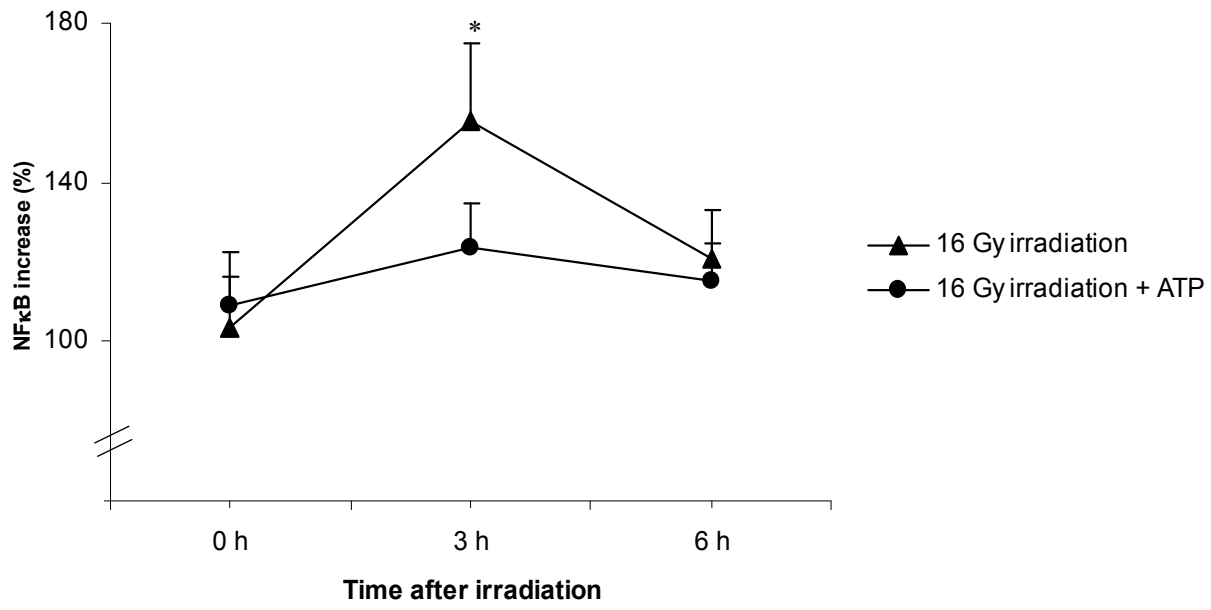

Figure 3: Effect of ATP $(300 \mu \mathrm{M})$ on NFKB activation at different time-points $(0,3$ and $6 \mathrm{~h})$ after irradiation in human blood. Results are expressed as percentage, with $100 \%$ representing $N F \kappa B$ release in non-irradiated blood. Data are expressed as mean values, with error bars representing SEM. ${ }^{*} \mathrm{P}<0.01$ compared to no irradiation.

\section{Effect of ATP on radiation-induced DNA damage}

Figure 4 shows the radiation-induced DNA damage as measured by the comet assay (tail moment) at different time-points after irradiation of blood. In nonirradiated blood, no DNA damage was observed at any time-point. Already immediately (10 $\mathrm{min}$ ) after irradiation a significant increase in DNA damage was seen. Although DNA damage decreased at $3 \mathrm{~h}$ and $6 \mathrm{~h}$ after irradiation, it remained significantly different from the non-irradiated samples at both time-points. ATP significantly attenuated the radiation-induced DNA damage at $0 \mathrm{~h}(29 \pm 8 \%), 3 \mathrm{~h}$ (45 $\pm 10 \%)$ and $6 \mathrm{~h}(58 \pm 10 \%)$ after irradiation. 


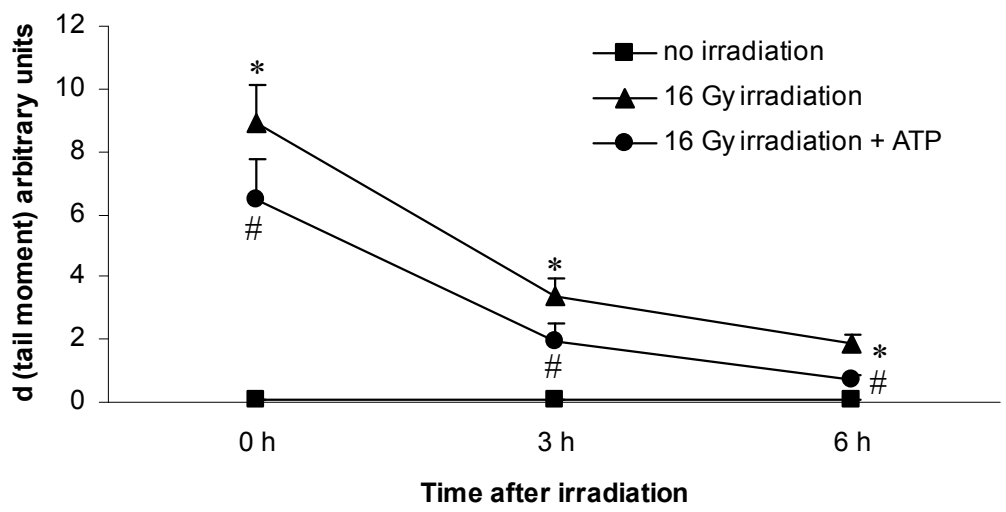

Figure 4: Effect of ATP on irradiation-induced DNA damage (tail moment) in white blood cells isolates from irradiated blood at different time-points $(0,3$ and $6 \mathrm{~h})$ after irradiation. Values are expressed as median \pm SEM. ${ }^{*} \mathrm{P}<0.05$ compared to no irradiation, ${ }^{\#} \mathrm{P}<0.05$ compared to irradiation in the absence of ATP.

\section{Effect of ATP on radiation-induced oxidative stress}

Because of the instability of GSH in blood, GSH and GSSG levels were measured only $10 \mathrm{~min}$ (immediately) after irradiation. As shown in table 1, GSH levels were significantly decreased 10 min after irradiation. In the presence of ATP, GSH levels were not influenced after irradiation exposure. GSSG levels were significantly increased 10 min after irradiation both in the absence and presence of ATP. As a final point, the GSH/GSSG ratio, which was decreased significantly 10 min after irradiation, was not altered by ATP.

Table 1: Effect of ATP on GSH and GSSG levels immediately after irradiation of human blood ${ }^{\text {a) }}$

\begin{tabular}{llll}
\hline Condition & $\begin{array}{l}\text { GSH } \\
(\boldsymbol{\mu m o l} / \mathbf{g H b})\end{array}$ & $\begin{array}{l}\text { GSSG } \\
(\boldsymbol{\mu m o l} / \mathbf{g H b})\end{array}$ & GSH/GSSG ratio \\
\hline No irradiation & $10 \pm 0.5$ & $0.18 \pm 0.02$ & $55.7 \pm 3.5$ \\
Medium + irradiation & $8.7 \pm 0.2^{*}$ & $0.25 \pm 0.04^{*}$ & $34.8 \pm 5.8^{*}$ \\
ATP + irradiation & $9.1 \pm 0.2$ & $0.26 \pm 0.03^{*}$ & $35 \pm 3.5^{*}$ \\
\hline
\end{tabular}

a) Data are shown as mean \pm SEM in eight subjects ( ${ }^{*} \mathrm{P}<0.05$ compared to no irradiation). 
The TEAC value, a marker of total antioxidant capacity, and MDA, a marker of lipid peroxidation, were not significantly changed at any time-point after irradiation of blood. Also, none of the GSH-relating enzymes such as GPx, GST and GR were significantly changed at any time-points (data not shown).

\section{Discussion}

Damage to healthy tissue is a major radiation dose limiting factor in treatment of cancer. Although several compounds have been shown to possess the property of protecting various biological systems from deleterious effects of ionizing radiation, many of these compounds showed acute toxicity, limiting their clinical usefulness [6]. Therefore, development of protectors with minimal toxicity is of high clinical relevance.

The aim of the present study was to investigate the protective effects of the natural compound ATP on radiation-induced damage at different time-points after irradiation of human blood. To our knowledge, our study is the first study regarding the protective effects of ATP on radiation-induced inflammation and DNA damage in irradiated human blood ex vivo. Results showed that radiation induced a marked increase in TNF- $\alpha$ and IL-10 concentrations. ATP was able to protect against radiation-induced inflammation in blood by attenuating TNF- $\alpha$ release and increasing IL-10 release. Recently, we reported that ATP gave similar protective effects against LPS-PHA-induced inflammation in human blood [7]. Several studies have shown that concentrations of cytokines such as IL-6 and TNF- $\alpha$ were higher after irradiation in vivo [19-22]. Moreover, many studies have implicated the involvement of cytokines in the initiation and maintenance of radiation-induced toxicity [3, 23].

The inhibitory effect of ATP on the radiation-induced TNF- $\alpha$ release was largely blocked by 5 '-AMPS, indicating that the $\mathrm{P}_{2} \mathrm{Y}_{11}$ receptor is involved. This is in agreement with our earlier study [8], in which we showed that the inhibition of LPSPHA-induced TNF- $\alpha$ release by ATP was mediated via $\mathrm{P}_{2} \mathrm{Y}_{11}$ receptor activation. In contrast to our previous publication [8], the stimulatory effect of ATP on the radiation-induced $\mathrm{IL}-10$ release did not involve the $\mathrm{P} 2 \mathrm{Y}_{12}$ receptor. One possible explanation could be that the receptor and its transduction system are damaged by radiation [24]. Another possible explanation could be that another P2Y receptor is involved in the stimulatory effect of ATP on radiation-induced IL-10 release. It is also possible that IL-10 is not yet maximally expressed at $6 \mathrm{~h}$ after irradiation, and consequently the stimulatory effect of ATP on IL-10 release may be higher at later time-points after irradiation.

The transcription factor $\mathrm{NF} \kappa \mathrm{B}$ plays an important role during an inflammatory response by regulating the expression of many downstream genes, including 
cytokines in inflammatory responses [25]. In our study, NFKB activation was transiently increased $3 \mathrm{~h}$ after irradiation of blood. ATP showed a non-significant attenuation on the $\mathrm{NF} \kappa \mathrm{B}$ activation induced $3 \mathrm{~h}$ after irradiation exposure. The temporal relationship between the radiation-induced activation of $N F \kappa B$ and increases in TNF- $\alpha$ expression suggests that activation of NFKB by irradiation could play a role in the induction of this cytokine. Production of ROS upon irradiation could provide a possible mechanism for the activation of $N F \kappa B$ as has been seen in several cell types [26-30]. Linard et al [31], showed that whole body irradiation of rats induced a cascade of inflammatory responses, which was dependent on the transcription factor NFKB.

Exposure to ionizing radiation produces a variety of lesions in DNA such as single strand breaks, double strand breaks, DNA-DNA and DNA protein cross-links together with damage to nucleotide bases [32]. Our study showed that DNA damage occurred immediately after irradiation, followed by a decrease of this damage indicating a repair mechanism, which continues at 3 and $6 \mathrm{~h}$ after irradiation. ATP administration before radiation resulted in a significant inhibition of the radiationinduced comet tail length at all time-points after irradiation, indicating the protection of cellular DNA. Several groups have demonstrated initial DNA damage after irradiation of lymphocytes followed by repair [33, 34]. We showed earlier, by electron spin measurements, that ATP attenuated spin-trap-hydroxyl radical $\left(\mathrm{OH}^{\circ}\right)$ adduct formation in the Fenton reaction [35]. Thus, the protective effects of ATP on radiation-induced DNA damage may be partly due to scavenging of $\mathrm{OH}^{\circ}$, produced by irradiation.

It is known that in physiological processes, GSH acts as a protective agent against ROS. GSH participates non-enzymatically in protection against radiation damage. In our study, we observed decreased levels of GSH in irradiated blood, presumably due to its utilization by ROS. Pretreatment of blood with ATP prior to irradiation, protected against this GSH depletion. Oxidized levels of GSSG were increased in irradiated blood, but were still increased in the presence of ATP. No effect of irradiation was seen on TEAC, MDA levels and activities of GPx, GST and GR. This finding contrast with data from Prasad et al. [36] who showed that in cultured lymphocytes, exposed to irradiation, GPx activity decreased. Also, whole body irradiation of mouse/rats, induced a reduction in erythrocyte GR, GPx and GST activities [37, 38] and increase in MDA levels [38].

Our observation that ATP inhibited radiation induced inflammation and DNA damage would suggest that ATP could be used as a protector against radiationinduced damage. Indeed, protective effects of ATP against radiation damage on normal tissues were observed in various animal models in vivo, as shown by enhanced survival rates [39, 40]. Moreover, Senagore et al. [41] demonstrated that intravenous ATP- $\mathrm{MgCl}_{2}$ infusions in pigs offered significant cytoprotection from pelvic radiotherapy by diminishing colorectal seromuscular ischaemia and decreasing skin and subcutaneous tissue injury and inflammatory reactions. When 
compared with other possible protectors, ATP has the advantage of being a natural compound with little toxicity. Moreover, the anti-inflammatory properties of ATP in blood exposed to radiation, suggest the potential attenuation of complications, which are related to cytokine production. Besides these possible properties of ATP as a protector against radiation-induced injury, potential applications for ATP in cancer treatment have aroused increasing interest over the past decade [42]. At concentrations of 1-5 mM, extracellular ATP exerted cytostatic and cytotoxic effects on several tumour cell lines, which were stronger than the effect upon nontransformed mother cells [43-45]. Estrela et al [46] showed that the combination of radiotherapy and ATP administration reduced GSH-levels in tumour cells, but not in normal cells, offering a selective point of attack in cancer therapy. Both the groups of Estrela et al. [46] and Szeinfeld et al. [47] showed a markedly differential response to ATP plus radiation treatment in tumoural vs. healthy tissue, suggesting protection against radiation damage by ATP in healthy tissue, but not in tumour tissue. The therapeutic potential of ATP and other extracellular nucleotides in the treatment of cancer by signaling through $\mathrm{P} 2$ receptors has recently been reviewed by White et al. [48].

We conclude that ATP is able to attenuate radiation-induced DNA damage and inflammation in blood. Further work in vitro and in vivo will be needed to substantiate these findings and unravel underlying mechanisms. 


\section{References}

1 Movsas B., Raffin T.A., Epstein A.H. and Link C.J., Jr. Pulmonary radiation injury. Chest 1997; 111: 1061-1076.

2 Abratt R.P. and Morgan G.W. Lung toxicity following chest irradiation in patients with lung cancer. Lung Cancer 2002; 35: 103-109.

3 Morgan G.W. and Breit S.N. Radiation and the lung: a reevaluation of the mechanisms mediating pulmonary injury. Int J Radiat Oncol Biol Phys 1995; 31: 361-369.

4 McDonald S., Rubin P., Phillips T.L. and Marks L.B. Injury to the lung from cancer therapy: clinical syndromes, measurable endpoints, and potential scoring systems. Int $J$ Radiat Oncol Biol Phys 1995; 31: 1187-1203.

5 Hong J.H., Chiang C.S., Tsao C.Y., Lin P.Y., McBride W.H. and Wu C.J. Rapid induction of cytokine gene expression in the lung after single and fractionated doses of radiation. Int $J$ Radiat Biol 1999; 75: 1421-1427.

6 Nair C.K., Parida D.K. and Nomura T. Radioprotectors in radiotherapy. J Radiat Res (Tokyo) 2001; 42: 21-37.

7 Swennen E.L., Bast A. and Dagnelie P.C. Immunoregulatory effects of adenosine 5'triphosphate on cytokine release from stimulated whole blood. Eur J Immunol 2005; 35: 852858.

8 Swennen E.L., Bast A. and Dagnelie P.C. Purinergic receptors involved in the immunomodulatory effects of ATP in human blood. Biochem Biophys Res Commun 2006; 348: 1194-1199.

9 El-Tayeb A., Griessmeier K.J. and Muller C.E. Synthesis and preliminary evaluation of [3H]PSB-0413, a selective antagonist radioligand for platelet P2Y12 receptors. Bioorg Med Chem Lett 2005; 15: 5450-5452.

10 Hofmann M.A., Schiekofer S., Isermann B., Kanitz M., Henkels M., Joswig M., Treusch A., Morcos M., Weiss T., Borcea V., Abdel Khalek A.K., Amiral J., Tritschler H., Ritz E., Wahl P., Ziegler R., Bierhaus A. and Nawroth P.P. Peripheral blood mononuclear cells isolated from patients with diabetic nephropathy show increased activation of the oxidative-stress sensitive transcription factor NF-kappaB. Diabetologia 1999; 42: 222-232.

11 Mercken E.M., Hageman G.J., Schols A.M., Akkermans M.A., Bast A. and Wouters E.F. Rehabilitation decreases exercise-induced oxidative stress in chronic obstructive pulmonary disease. Am J Respir Crit Care Med 2005; 172: 994-1001.

12 Vandeputte C., Guizon I., Genestie-Denis I., Vannier B. and Lorenzon G. A microtiter plate assay for total glutathione and glutathione disulfide contents in cultured/isolated cells: performance study of a new miniaturized protocol. Cell Biol Toxicol 1994; 10: 415-421.

13 Fischer M.A., Gransier T.J., Beckers L.M., Bekers O., Bast A. and Haenen G.R. Determination of the antioxidant capacity in blood. Clin Chem Lab Med 2005; 43: 735-740.

14 Lux O., Naidoo D. and Salonikas C. Improved HPLC method for the simultaneous measurement of allantoin and uric acid in plasma. Ann Clin Biochem 1992; 29 ( Pt 6): 674675.

15 Lepage G., Munoz G., Champagne J. and Roy C.C. Preparative steps necessary for the accurate measurement of malondialdehyde by high-performance liquid chromatography. Anal Biochem 1991; 197: 277-283.

16 Paglia D.E. and Valentine W.N. Studies on the quantitative and qualitative characterization of erythrocyte glutathione peroxidase. J Lab Clin Med 1967; 70: 158-169.

17 McCormick $\mathrm{D}$. Method for the determination of erythrocyte glutathion reductase activity. Tietz NM, editor. Textbook of clinical chemistry. Philadelphia: WB Saunders Company 1986. 
18 Habig W.H. and Jakoby W.B. Assays for differentiation of glutathione S-transferases. Methods Enzymol 1981; 77: 398-405.

19 Cengiz M., Akbulut S., Atahan I.L. and Grigsby P.W. Acute phase response during radiotherapy. Int J Radiat Oncol Biol Phys 2001; 49: 1093-1096.

20 Gridley D.S., Bonnet R.B., Bush D.A., Franke C., Cheek G.A., Slater J.D. and Slater J.M. Time course of serum cytokines in patients receiving proton or combined photon/proton beam radiation for resectable but medically inoperable non-small-cell lung cancer. Int $J$ Radiat Oncol Biol Phys 2004; 60: 759-766.

21 Hong J.H., Chiang C.S., Campbell I.L., Sun J.R., Withers H.R. and McBride W.H. Induction of acute phase gene expression by brain irradiation. Int J Radiat Oncol Biol Phys 1995; 33: 619626.

22 Hallahan D.E. Radiation-Mediated Gene Expression in the Pathogenesis of the Clinical Radiation Response. Semin Radiat Oncol 1996; 6: 250-267.

23 Rubin P., Johnston C.J., Williams J.P., McDonald S. and Finkelstein J.N. A perpetual cascade of cytokines postirradiation leads to pulmonary fibrosis. Int J Radiat Oncol Biol Phys 1995; 33: 99-109.

24 Van der Vliet A. and Bast A. Effect of oxidative stress on receptors and signal transmission. Chem Biol Interact 1992; 85: 95-116.

25 Barnes P.J. and Karin M. Nuclear factor-kappaB: a pivotal transcription factor in chronic inflammatory diseases. N Engl J Med 1997; 336: 1066-1071.

26 Flohe L., Brigelius-Flohe R., Saliou C., Traber M.G. and Packer L. Redox regulation of NFkappa B activation. Free Radic Biol Med 1997; 22: 1115-1126.

27 Schoonbroodt S. and Piette J. Oxidative stress interference with the nuclear factor-kappa B activation pathways. Biochem Pharmacol 2000; 60: 1075-1083.

28 Rahman I. Oxidative stress, transcription factors and chromatin remodelling in lung inflammation. Biochem Pharmacol 2002; 64: 935-942.

29 Chandel N.S., Trzyna W.C., McClintock D.S. and Schumacker P.T. Role of oxidants in NFkappa $\mathrm{B}$ activation and TNF-alpha gene transcription induced by hypoxia and endotoxin. $J$ Immunol 2000; 165: 1013-1021.

30 Li N. and Karin M. Is NF-kappaB the sensor of oxidative stress? Faseb $J$ 1999; 13: 11371143.

31 Linard C., Marquette C., Mathieu J., Pennequin A., Clarencon D. and Mathe D. Acute induction of inflammatory cytokine expression after gamma-irradiation in the rat: effect of an NF-kappaB inhibitor. Int J Radiat Oncol Biol Phys 2004; 58: 427-434.

$32 \mathrm{Li}$ L., Story M. and Legerski R.J. Cellular responses to ionizing radiation damage. Int J Radiat Oncol Biol Phys 2001; 49: 1157-1162.

33 Muller W.U., Bauch T., Stuben G., Sack H. and Streffer C. Radiation sensitivity of lymphocytes from healthy individuals and cancer patients as measured by the comet assay. Radiat Environ Biophys 2001; 40: 83-89.

34 Burger S., Schindler D., Fehn M., Muhl B., Mahrhofer H., Flentje M., Hoehn H., Seemanova E. and Djuzenova C.S. Radiation-induced DNA damage and repair in peripheral blood mononuclear cells from Nijmegen breakage syndrome patients and carriers assessed by the Comet assay. Environ Mol Mutagen 2006; 47: 260-270.

35 Swennen E.L., Dagnelie P.C. and Bast A. ATP inhibits hydroxyl radical formation and the inflammatory response of stimulated whole blood even under circumstances of severe oxidative stress. Free Radic Res 2006; 40: 53-58.

36 Prasad N.R., Menon V.P., Vasudev V. and Pugalendi K.V. Radioprotective effect of sesamol on gamma-radiation induced DNA damage, lipid peroxidation and antioxidants levels in cultured human lymphocytes. Toxicology 2005; 209: 225-235. 
37 Navarro J., Obrador E., Pellicer J.A., Aseni M., Vina J. and Estrela J.M. Blood glutathione as an index of radiation-induced oxidative stress in mice and humans. Free Radic Biol Med 1997; 22: 1203-1209.

38 Emin Buyukokuroglu M., Taysi S., Koc M. and Bakan N. Dantrolene protects erythrocytes against oxidative stress during whole-body irradiation in rats. Cell Biochem Funct 2003; 21: 127-131.

39 Szeinfeld D. and De Villiers N. Radioprotective properties of ATP and modification of acid phosphatase response after a lethal dose of whole body $\mathrm{p}(66 \mathrm{MeV}) / \mathrm{Be}$ neutron radiation to BALB/c mice. Cancer Biochem Biophys 1992; 13: 123-132.

40 Szeinfeld D. and de Villiers N. Response of normal BALB/c mouse tissue to $p(66 \mathrm{MeV}) / \mathrm{Be}$ fast neutron radiation: protection by exogenous ATP. Strahlenther Onkol 1992; 168: 174-178.

41 Senagore A.J., Milsom J.W., Walshaw R.K., Mostoskey U., Dunstan R. and Chaudry I.H. Adenosine triphosphate-magnesium chloride in radiation injury. Surgery 1992; 112: 933-939.

42 Agteresch H.J., Dagnelie P.C., van den Berg J.W. and Wilson J.H. Adenosine triphosphate: established and potential clinical applications. Drugs 1999; 58: 211-232.

43 Agteresch H.J., Van Rooijen M., van den Berg J., Minderman-voortman G., Wilson J.H. and Dagnelie P.C. Growth inhibition of lung cancer cells by adenosine 5'-triphosphate. drug development research 2003; 60: 196-203.

44 Yamada T., Okajima F., Akbar M., Tomura H., Narita T., Ohwada S., Morishita Y. and Kondo $\mathrm{Y}$. Cell cycle arrest and the induction of apoptosis in pancreatic cancer cells exposed to adenosine triphosphate in vitro. Oncol Rep 2002; 9: 113-117.

45 Conigrave A.D., van der Weyden L., Holt L., Jiang L., Wilson P., Christopherson R.I. and Morris M.B. Extracellular ATP-dependent suppression of proliferation and induction of differentiation of human HL-60 leukemia cells by distinct mechanisms. Biochem Pharmacol 2000; 60: 1585-1591.

46 Estrela J.M., Obrador E., Navarro J., Lasso De la Vega M.C. and Pellicer J.A. Elimination of Ehrlich tumours by ATP-induced growth inhibition, glutathione depletion and X-rays. Nat Med 1995; 1: 84-88.

47 Szeinfeld D. and de Villiers N. Cholinesterase response in the rhabdomyosarcoma tumour and small intestine of the BALB/c mice and the radioprotective actions of exogenous ATP after lethal dose of neutron radiation. Strahlenther Onkol 1993; 169: 311-316.

48 White N. and Burnstock G. P2 receptors and cancer. Trends Pharmacol Sci 2006; 27: 211217. 


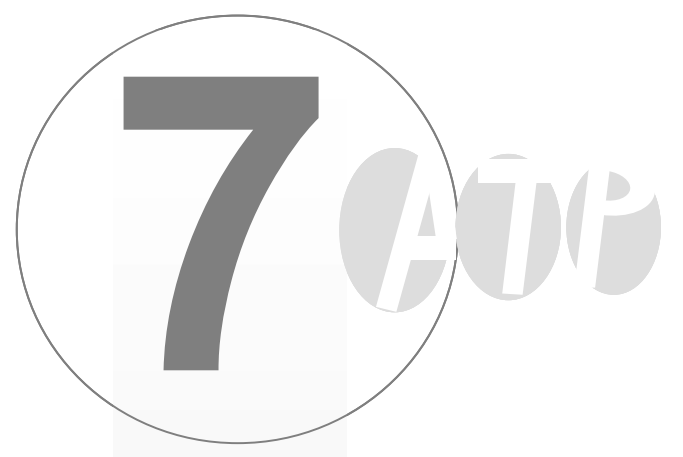

Inflammatory and oxidative stress status in NSCLC patients and the ex vivo immunomodulatory effects of ATP in stimulated blood: a pilot study

\author{
Els L.R. Swennen \\ Shireen A.W. van den Broek \\ Agnes W. Boots \\ Ilja C.W. Arts \\ Pieter A. van den Brandt
}

Aalt Bast

Pieter C. Dagnelie

Submitted 


\section{Abstract}

Cancer may be associated with inflammation and oxidative stress. Moreover, cancer-related side effects, such as fatigue and weight loss, are associated with an overproduction of pro-inflammatory cytokines. The first aim of this study was to determine the oxidative stress and inflammatory status in non-small-cell lung cancer (NSCLC) patients compared to a matched control group. Secondly, the potential of the natural compound adenosine 5'-triphosphate (ATP) to modulate cytokine release in ex vivo stimulated blood was assessed in both groups. NSCLC patients, selected for treatment with radiotherapy, as well as healthy controls matched for age, gender and smoking history were enrolled. Measurements included determination of total plasma antioxidant capacity, levels of uric acid, glutathione (GSH), GSH-related enzymes, malondialdehyde (MDA), tumour necrosis factoralpha (TNF- $\alpha$ ), interleukin (IL)-10, C-reactive protein, haptoglobin, albumin and prealbumin. Compared to the control group, NSCLC patients showed a significantly lower glutathione peroxidase (GPx) activity, while glutathione-S-transferase (GST) activity and MDA levels were significantly higher. Basal levels of TNF- $\alpha$ were significantly increased in the cancer group, whereas basal albumin levels were significantly decreased. ATP significantly inhibited TNF- $\alpha$ release and stimulated IL10 release in ex vivo lipopolysaccharide (LPS)-phytohemagglutinin (PHA)stimulated blood in a concentration-dependent manner, both in the cancer and control group. Our results show an impaired antioxidant system and an increased inflammatory status in NSCLC compared to healthy subjects. Moreover, the antiinflammatory effects of ATP in stimulated blood may partly explain the previously reported in vivo effects of ATP infusions in patients with advanced NSCLC. 


\section{Introduction}

Cancer, a disease characterized by uncontrolled growth and spread of abnormal cells, is one of the major causes of death in humans [1]. Lung cancer is a common cancer with high mortality due to late diagnosis; the major risk factor is smoking [13]. Non-small-cell lung cancer (NSCLC), which accounts for about $80 \%$ of all lung cancers, is the type of cancer with the highest incidence and mortality in men, and the third highest in women. The overall five-year survival rates of these patients remain relatively poor, ranging from $70 \%$ for stage IA patients to $25 \%$ for stage IIIA patients [4].

Cancer is known to be associated with inflammation [5-8]. Moreover, secondary symptoms of NSCLC, such as fatigue and weight loss, have been shown to correlate with an overproduction of cytokines such as tumour necrosis factor-alpha (TNF- $\alpha$ ) and C-reactive protein (CRP) [9-13]. Increased oxidative stress is a characteristic feature of chronic inflammation and the role of oxidative stress in the carcinogenesis process was recently reviewed by Valko et al. [14]. In addition, there is substantial evidence indicating that the redox balance in cancer cells is impaired relative to normal human cells $[15,16]$.

One approach to reduce side effects in cancer patients and thereby improving quality of life of these patients could be the administration of an anti-inflammatory agent. Moreover, this reduced inflammatory reaction will lead to less reactive oxygen species (ROS) production and thereby a decreased level of oxidative stress. We earlier showed that the natural compound adenosine 5'-triphosphate (ATP) was able to down-regulate TNF- $\alpha$ and to up-regulate interleukin (IL)-10 release in lipopolysaccharide (LPS)-phytohemagglutinin (PHA)-stimulated blood of healthy subjects [17]. Moreover, Agteresch et al. [18-20] showed in a randomized clinical trial that appetite, weight, muscle strength, fatigue and physical and functional quality of life remained stable for 6 months in the ATP group, but progressively deteriorated in the control group, receiving usual palliative care only.

The first aim of the present study was to determine both the oxidative stress and inflammatory status in NSCLC relative to matched healthy control subjects. Secondly, we investigated the potential anti-inflammatory properties of ATP in blood of NSCLC patients. For this purpose, blood was ex vivo exposed to LPS and PHA, both inducers of cytokines, in the absence and presence of ATP. 


\section{Material and methods}

\section{General information}

The study protocol was approved by the Ethical Committee of Maastricht University and MAASTRO clinic. Informed consent was obtained from all participants prior to inclusion.

\section{Patients}

Eligible were current or ex-smoking patients with histological or cytological confirmation of NSCLC, who had been selected by their treating pulmonologist for either high-dose radiotherapy (tumour stage I, II, IIIA and IIIB), aimed at locoregional tumour control, or for palliative radiotherapy (tumour stage IIIB or IV), aimed at palliation of complaints of intrathoracal tumour volume in patients with poor prognosis (both either with or without chemotherapy pretreatment). Patients had been diagnosed with the primary tumour between June 2005 and September 2006. All NSCLC patients were recruited by participating physicians in three regional hospitals located in Heerlen and Eindhoven, in the south-eastern part of The Netherlands, and Overpelt, Belgium, between November 2005 and September 2006. Patients with diagnosis of bronchial asthma were excluded. Blood was sampled prior to starting the first radiotherapy treatment.

\section{Controls}

The control group consisted of 12 smoking healthy volunteers, matched for age, gender and smoking history compared to the group of NSCLC patients. All healthy volunteers were recruited from an elderly home in Maastricht, in the south-eastern part of The Netherlands in a period between August 2006 and September 2006. The percentage weight loss in both groups was calculated by the following formula: [(weight six months ago - actual weight) / weight three years ago $\times 100 \%$.

\section{Blood sampling}

Blood samples were collected in EDTA-containing vacutainer tubes (Vacutainer, Becton-Dickinson) and kept on ice until processing, which occurred within one hour after blood collection. Blood was aliquoted into eppendorf cups for the analysis of glutathione-related enzymes. For analysis of reduced glutathione (GSH) and oxidized glutathione (GSSG), 1.3\% sulphosalicilic acid (SSA) in $100 \mathrm{mM} \mathrm{HCl}$ was used to preserve the blood samples. For ATP analysis, 8\% perchloric acid (PCA) was added to blood. The remaining blood was centrifuged (3500 rpm for $10 \mathrm{~min}$ at $4^{\circ} \mathrm{C}$ ) to obtain plasma for cytokine and malondialdehyde (MDA) analysis. 
Deproteinization of an aliquot of this plasma, using $10 \%$ trichloric acid followed by centrifugation (13000 rpm for $5 \mathrm{~min}$ at $4^{\circ} \mathrm{C}$ ), was done for measurement of the trolox equivalent antioxidant capacity (TEAC). After processing, all samples were stored at $-80^{\circ} \mathrm{C}$ until analysis.

\section{Blood-based cytokine production assay}

Blood was collected in a heparine-containing vacutainer tube (Vacutainer, BectonDickinson, $170 \mathrm{IU}$ ) and within one hour after blood collection, blood was aliquoted into 24-well plates and incubated with medium (control) or $300 \mu \mathrm{M} \mathrm{ATP}$ at $\mathrm{t}=-30 \mathrm{~min}$ followed at $\mathrm{t}=0 \mathrm{~min}$ by LPS-PHA stimulation at $37^{\circ} \mathrm{C}$ and $5 \% \mathrm{CO}_{2}$ for $24 \mathrm{~h}$ as described previously [17].

\section{Inflammatory markers}

Cytokines in the blood-based cytokine production assay were quantified using PeliKine Compact human enzyme linked immune sorbent assay (ELISA) kits (CLB/Sanquin, The Netherlands) based on appropriate and validated sets of monoclonal antibodies. Basal cytokine levels in plasma were quantified using R\&D high sensitivity ELISA kits (Quantikine HS, Minneapolis, United States of America). Assays were performed as described in the manufacturer's instructions.

Serum CRP and albumin levels were determined by Hitachi Modular equipment (Roche Diagnostics $\mathrm{GmbH}$, Mannheim, Germany). Serum haptoglobin and prealbumin levels were determined by Behring BN-Il equipment (Dade Behring $\mathrm{GmbH}$, Marburg, Germany). Assays were performed by the Medical Laboratory of Dr. Stein \& Colleges (Maastricht, The Netherlands) as described in the manufacturer's instructions. The erythrocyte sedimentation rate $(E S R, \mathrm{~mm} / \mathrm{h})$ was also determined.

\section{Blood analyses}

Hematology analyses such as hemoglobin, leukocytes, erythrocytes and monocytes were determined by the Sysmex/XE-2100 equipment. Clinical chemistry parameters including cholesterol, triglycerides, aspartate aminotransferase (AST), alanine aminotransferase (ALT), gamma glutamyl transferase (gamma-GT), lactate dehydrogenase (LDH), creatinine, vitamin B12 and folic acid were determined by Hitachi Modular equipment (Roche Diagnostics $\mathrm{GmbH}$, Mannheim, Germany). Assays were performed as described in the manufacturer's instructions.

\section{ATP measurement}

ATP in blood was determined as previously described by Schweinsberg et al. [21]. Briefly, blood was treated with 8\% PCA immediately after blood collection and 
frozen at $-80^{\circ} \mathrm{C}$. Prior to analysis, samples were thawed on ice and centrifuged at $12000 \mathrm{rpm}, 10 \mathrm{~min}, 4^{\circ} \mathrm{C}$. The supernatant was neutralized $\left(\mathrm{pH} \mathrm{6-7)}\right.$ with $2 \mathrm{M} \mathrm{K}_{2} \mathrm{CO}_{3}$ in $6 \mathrm{M} \mathrm{KOH}$ and centrifuged (14.000 rpm, $10 \mathrm{~min}, 4^{\circ} \mathrm{C}$ ). In a single run, ATP and its metabolites were quantified by high performance liquid chromatography (HPLC). Erythrocyte ATP levels are correlated to haematocrit levels.

\section{Oxidative stress markers}

\section{TEAC and uric acid}

The TEAC value, which gives the capacity of a solution to neutralize the stable 2,2'azino-bis(3-ethylbenzothiazoline-6-sulfonate (ABTS) radical, was determined as previously described by Fischer et al. [22] and is expressed as $\mu \mathrm{M}$ Trolox equivalent. Uric acid was measured in plasma, deproteinated with a final concentration of $5 \%$ trichloric acid, using a HPLC method as described by Lux et al. [23]. The system (Agilent, Palo Alto, CA, USA) consisted of a Hypersil ODS C-18 end-capped column, $125 \times 4 \mathrm{~mm}$, particle size $5 \mu \mathrm{M}$ (Agilent, Palo Alto, CA, USA) with a mobile phase of $0.1 \%$ trifluoric acid in MilliQ. UV detection was performed at $292 \mathrm{~nm}$.

\section{$M D A$}

The determination of MDA was based on the formation of a colored adduct of MDA with 2-thiobarbituric acid (TBA) using a HPLC method as described previously by Lepage et al. [24].

\section{GSH and GSSG}

Immediately after blood collection, to minimize the ability of GSH to form mixed disulfides, GSH/GSSG samples were stabilized by adding $1.3 \%$ SSA. GSH and GSSG calibrators were prepared freshly, and contained the same concentrations of SSA as the samples. GSH levels were determined by measuring the increase in absorbance, caused by the GSH driven reduction of 5',5' dithiobis-2-nitrobenzoic acid (DTNB) during the enzymatic reaction started by adding GSSG reductase, using the recycling method described by Vandeputte et al. [25]. GSSG was measured by the same protocol as GSH, with the only difference that this assay involves a GSH derivatization by 2-vinylpyridine [25].

\section{Glutathione peroxidase (GPx)}

The selenium-dependent GPx activity, with hydrogen peroxide $\left(\mathrm{H}_{2} \mathrm{O}_{2}\right)$ as substrate, was determined by measuring the decrease in absorbance due to the consumption of NADPH [26]. GPx activity was calculated using the molar absorbance coefficient of NADPH. 


\section{Glutathione reductase (GR)}

GR activity was determined by measuring the decrease in absorbance caused by the consumption of NADPH in the enzymatic reduction of GSSG to GSH by GR [27]. The activity was calculated using the molar absorbance coefficient of NADPH.

\section{Glutathione-S-transferase (GST)}

GST activity was determined by the GST catalyzed reaction of 1-chloro-2,4dinitrobenzene with GSH, resulting in a yellow colored product, GSHdinitrobenzene, of which the increase in absorbance was measured [28]. The activity of GST in the samples was calculated using the molar absorbance coefficient of GSH-dinitrobenzene.

\section{Statistics}

Data of patients and controls were compared using the Mann-Whitney-U-test. Spearman's rank correlation coefficients were calculated to appraise the relation between TNF- $\alpha$ or IL-10 levels in the absence and presence of ex vivo added ATP. Two-tailed P-values of 0.05 or less were considered statistically significant.

\section{Results}

Ten NSCLC patients and 12 healthy controls were enrolled in the study, who were all current smokers. Characteristics of the study populations are summarized in table 1.

Table 1: Characteristics of non-small-cell lung cancer patients and controls.

\begin{tabular}{lll}
\hline & $\begin{array}{l}\text { Patients } \\
(\mathrm{n}=10)\end{array}$ & $\begin{array}{l}\text { Controls } \\
(\mathrm{n}=12)\end{array}$ \\
\hline Gender (M/F) & $8 / 4$ & $6 / 6$ \\
Age (years, mean \pm SEM) & $70.1 \pm 3.0$ & $78.1 \pm 2.2$ \\
Smoking history (pack-years, mean \pm SEM) & $37.4 \pm 9.1$ & $27.2 \pm 4.5$ \\
Body mass index (mean \pm SEM) & $23.7 \pm 1.4$ & $24.3 \pm 0.4$ \\
Weight loss $(\geq 5 \% /<5 \%)$ & $6 / 4$ & $2 / 12$ \\
Chemotherapy as pre-treatment (yes/no) & $5 / 5$ & not applicable \\
Stage of lung cancer: I-II & 4 & not applicable \\
\multicolumn{1}{c}{ IIIA/B-IV } & 6 & not applicable \\
\hline
\end{tabular}


Six out of 10 patients and two out of 12 healthy controls had lost more than $5 \%$ body weight over the last 6 months. Five out of 10 patients had been pre-treated with chemotherapy. Four patients had tumour stage I or II and six patients had advanced cancer (stage IIIA/B or IV). At the moment of blood sampling, the time since diagnosis of the primary tumour was $2.8 \pm 0.5$ months (mean \pm SEM), and the time occurred since the last chemotherapy treatment in five out of ten patients was $1.5 \pm$ 0.3 months. Results of hematological and biochemical analysis of blood are presented in table 2.

Table 2: Hematological and biochemical parameters of patients with non-small cell lung cancer and control subjects ${ }^{\text {a) }}$.

\begin{tabular}{|c|c|c|c|}
\hline Parameters & Patients & Controls & Normal values \\
\hline Hemoglobin $(\mathrm{mmol} / \mathrm{l})$ & $7.2 \pm 0.4^{*}$ & $9.3 \pm 0.2$ & $8.1-10.7$ \\
\hline Erythrocytes (/pl) & $3.9 \pm 0.2^{* *}$ & $4.8 \pm 0.1$ & $4.2-5.7$ \\
\hline Hematocrit (I/I) & $0.4 \pm 0.02^{*}$ & $0.50 \pm 0.01$ & $0.39-0.55$ \\
\hline Leucocytes (/nl) & $9.7 \pm 2.1$ & $7.3 \pm 0.6$ & $4.0-11.0$ \\
\hline Thrombocytes (/nl) & $288.9 \pm 38$ & $205 \pm 13.3$ & $150-400$ \\
\hline Lymphocytes (\%) & $21 \pm 4.2^{*}$ & $30.9 \pm 2.7$ & $22-50$ \\
\hline Monocytes (\%) & $6.7 \pm 1$ & $6.7 \pm 0.7$ & $<18.0$ \\
\hline Neutrophilic granulocytes (\%) & $68.8 \pm 5$ & $59.8 \pm 2.5$ & $37-70$ \\
\hline Eosinophilic granulocytes (\%) & $1.7 \pm 0.3$ & $2 \pm 0.4$ & $<4.1$ \\
\hline Basophilic granulocytes (\%) & $0.6 \pm 0.1$ & $0.5 \pm 0.1$ & $<1.5$ \\
\hline Cholesterol (mmol/l) & $4.6 \pm 0.3$ & $5.2 \pm 0.4$ & $<6.50$ \\
\hline Bilirubin total $(\mu \mathrm{mol} / \mathrm{l})$ & $6.3 \pm 1$ & $11.1 \pm 1.2$ & $<17$ \\
\hline AST (U/I) & $37 \pm 10.6$ & $30.4 \pm 5.5$ & $10.0-50.0$ \\
\hline ALT (U/l) & $29.6 \pm 9.2$ & $23 \pm 3.8$ & $<50$ \\
\hline Gamma-GT (U/I) & $50.5 \pm 12.2$ & $78.4 \pm 35.2$ & $<66$ \\
\hline Alkaline phosphatase (U/l) & $107.7 \pm 8.7$ & $92.5 \pm 5.6$ & $40-129$ \\
\hline Creatinine $(\mu \mathrm{mol} / \mathrm{l})$ & $92.5 \pm 8.5$ & $92 \pm 6.5$ & $<124$ \\
\hline Vitamin B12 (pmol/l) & $270.2 \pm 37.1$ & $410.3 \pm 111.9$ & $145-639$ \\
\hline Folic acid (nmol/l) & $9.4 \pm 1$ & $15.6 \pm 3.7$ & $7.0-39.7$ \\
\hline Ferritin $(\mu \mathrm{g} / \mathrm{l})$ & $328.7 \pm 58$ & $271.7 \pm 129$ & $30-400$ \\
\hline Triglycerides $(\mathrm{mmol} / \mathrm{l})$ & $1.3 \pm 0.1$ & $1.7 \pm 0.2$ & $0.57-2.28$ \\
\hline $\mathrm{LDH}(\mathrm{U} / \mathrm{l})$ & $275.5 \pm 45.9^{*}$ & $182.5 \pm 9.5$ & $<295$ \\
\hline ATP in erythrocytes $(\mu \mathrm{M})$ & $2038 \pm 94$ & $1993 \pm 100$ & \\
\hline
\end{tabular}


Hemoglobin levels, hematocrit levels, erythrocytes, lymphocytes were significantly lower in cancer patients compared to the control group. Plasma lactate dehydrogenase (LDH) levels were significantly increased in the patients compared to the control group. The other parameters, such as erythrocyte ATP levels, were not significantly different between the groups.

As shown in table 3, GPx activity was significantly lower in cancer patients than in controls, and MDA levels and GST activity were significantly higher in cancer patients compared to controls. GSH, GSSG, uric acid, TEAC and GR activity were not significantly different between the NSCLC patients and their matched controls.

Table 3: Markers of oxidative stress in non-small-cell lung cancer patients and controls ${ }^{\text {a) }}$.

\begin{tabular}{lll}
\hline & Patients & Controls \\
\hline GSH $(\mu \mathrm{mol} / \mathrm{gHb})$ & $8.7 \pm 0.5$ & $7.6 \pm 0.5$ \\
GSSG $(\mu \mathrm{mol} / \mathrm{gHb})$ & $0.4 \pm 0.1$ & $0.4 \pm 0.05$ \\
Uric acid $(\mu \mathrm{M})$ & $340.1 \pm 27.4$ & $306.3 \pm 13.9$ \\
TEAC-uric acid $(\mu \mathrm{M})$ & $1039.4 \pm 57.5$ & $1007.2 \pm 57.3$ \\
MDA $(\mu \mathrm{M})$ & $1.3 \pm 0.04^{*}$ & $1.1 \pm 0.02$ \\
GPx $\left(\mu \mathrm{mol} \mathrm{H}_{2} \mathrm{O}_{2} / \mathrm{min} \mathrm{gHb}\right)$ & $17.4 \pm 0.9^{*}$ & $20.6 \pm 0.9$ \\
GST $(\mathrm{U} / \mathrm{gHb})$ & $4.6 \pm 0.7^{*}$ & $2.5 \pm 0.3$ \\
GR $(\mathrm{U} / \mathrm{gHb})$ & $6.4 \pm 0.9$ & $6.3 \pm 0.6$ \\
\hline
\end{tabular}

a) Data are expressed as mean \pm SEM. ${ }^{*}$ P $<0.05$ compared to controls. GSH (reduced glutathione), GSSG (oxidized glutathione), TEAC (Trolox equivalent antioxidant capacity), GPx (glutathione peroxidase), GST (glutathione-S-transferase), GR (glutathione reductase).

Table 4 shows the inflammatory markers in patients and control subjects. Basal levels of the pro-inflammatory cytokine TNF- $\alpha$ in plasma were significantly increased in cancer patients compared to their matched controls. Serum levels of albumin were significantly decreased in the patient group compared to the control group. Serum levels of CRP and haptoglobin as well as erythrocyte sedimentation rate (ESR) were higher in cancer patients than in the control group, but these differences did not reach statistical significance. 
Table 4: Markers of inflammation in non-small-cell lung cancer patients and controls ${ }^{\text {a) }}$.

\begin{tabular}{lll}
\hline & Patients & Controls \\
\hline TNF- $\alpha(\mathrm{pg} / \mathrm{ml})$ & $4.3 \pm 0.3^{*}$ & $2.9 \pm 0.2$ \\
$\mathrm{IL}-10(\mathrm{pg} / \mathrm{ml})$ & $16.9 \pm 2.2$ & $18.1 \pm 3.8$ \\
C-reactive protein $(\mathrm{mg} / \mathrm{l})$ & $34.1 \pm 15.3$ & $6.8 \pm 1.2$ \\
Haptoglobin $(\mathrm{g} / \mathrm{l})$ & $2.9 \pm 0.6$ & $1.8 \pm 0.2$ \\
Albumin $(\mathrm{g} / \mathrm{l})$ & $38.4 \pm 1.4^{*}$ & $46.7 \pm 0.5$ \\
Pre-albumin $(\mathrm{mg} / \mathrm{l})$ & $199.7 \pm 33.1$ & $241.2 \pm 13.6$ \\
Erythrocyte sedimentation rate $(\mathrm{mm} / \mathrm{h})$ & $46.6 \pm 11.2$ & $27.2 \pm 3.4$ \\
\hline
\end{tabular}

a) Data are expressed as mean \pm SEM. ${ }^{*} \mathrm{P}<0.01$ compared to control.

Antioxidant and cytokine levels of male and female patients were similar (data not shown). Moreover, antioxidant and cytokine levels were not correlated with age. Compared to patients not having any chemotherapy treatment $(n=5)$, the group of patients who had prior treatment with chemotherapy $(n=5)$, showed significantly lower levels of pre-albumin $(125 \pm 30 \mathrm{mg} / \mathrm{l}$ (mean \pm SEM) vs. $274 \pm 36 \mathrm{mg} / \mathrm{l}$; $\mathrm{P}<0.02)$, erythrocytes $(3.3 \pm 0.12 / \mathrm{pl}$ vs. $4.5 \pm 0.08 / \mathrm{pl} ; \mathrm{P}<0.02)$ and hemoglobin $(6.16 \pm 0.32 \mathrm{mmol} / \mathrm{l}$ vs. $8.4 \pm 0.17 \mathrm{mmol} / \mathrm{l} ; \mathrm{P}<0.02)$; and tended to display slightly lower levels of GSH $(8 \pm 0.4 \mu \mathrm{mol} / \mathrm{gHb}$ vs. $9.6 \pm 0.9 \mu \mathrm{mol} / \mathrm{gHb} ; \mathrm{P}=0.2)$, TEAC (1218 $\pm 66 \mu \mathrm{M}$ vs. $1486 \pm 67 \mu \mathrm{M} ; \mathrm{P}=0.1)$, uric acid $(269 \pm 27 \mu \mathrm{M}$ vs. $388 \pm 28 \mu \mathrm{M} ; \mathrm{P}=0.2)$ and higher levels of GSSG $(0.57 \pm 0.2 \mu \mathrm{mol} / \mathrm{gHb}$ vs. $0.24 \pm 0.05 \mu \mathrm{mol} / \mathrm{gHb} ; \mathrm{P}=0.1)$ and ESR ( $63 \pm 19 \mathrm{~mm} / \mathrm{h}$ vs. $30 \pm 9 \mathrm{~mm} / \mathrm{h} ; \mathrm{P}=0.06)$.

Compared to patients not having any weight loss $(n=4)$, the group of patients who had weight loss $(n=6)$, tended to display higher levels of LPS-PHA-stimulated TNF- $\alpha$ (11938 $\pm 1902 \mathrm{pg} / \mathrm{ml}$ vs. $5053 \pm 1624 \mathrm{pg} / \mathrm{ml}$; $\mathrm{P}=0.06)$.

Compared to the early stages (stage I/II) NSCLC patients $(n=4)$, advanced stages (stage IIIA-B/IV) NSCLC patients $(n=6)$ showed significantly lower levels of albumin (35 $\pm 1 \mathrm{~g} / \mathrm{l}$ vs. $43 \pm 1 \mathrm{~g} / \mathrm{l} ; \mathrm{P}=0.02)$ and significantly higher levels of ESR $(64 \pm 14$ $\mathrm{mm} / \mathrm{h}$ vs. $20 \pm 4 \mathrm{~mm} / \mathrm{h} ; \mathrm{P}=0.03)$ and tended to display higher levels of CRP $(47 \pm 22$ $\mathrm{mg} / \mathrm{l}$ vs. $7 \pm 4 \mathrm{mg} / \mathrm{l} ; \mathrm{P}=0.1$ ) and haptoglobin ( $3.6 \pm 0.8 \mathrm{~g} / \mathrm{l}$ vs. $1.8 \pm 0.4 \mathrm{~g} / \mathrm{l} ; \mathrm{P}=0.1$ ).

Ex vivo stimulation of blood with LPS-PHA for $24 \mathrm{~h}$ showed a non-significant trend of higher TNF- $\alpha$ concentrations and lower IL-10 concentrations in the patient group compared to the control group (TNF- $\alpha$ : $10134 \pm 1540 \mathrm{pg} / \mathrm{ml}$ in patients vs. $8572 \pm$ $1203 \mathrm{pg} / \mathrm{ml}$ in controls; IL-10: $1212 \pm 344 \mathrm{pg} / \mathrm{ml}$ in patients vs. $1478 \pm 186 \mathrm{pg} / \mathrm{ml}$ in controls). 
As shown in figure $1 \mathrm{~A}$ and $\mathrm{B}$, ATP inhibited the LPS-PHA-induced TNF- $\alpha$ production and stimulated the LPS-PHA-induced IL-10 production in the NSCLC patient group. Similar effects were observed in the matched controls, confirming our earlier results [17]. The observed immunomodulatory effects of ATP on TNF- $\alpha$ and IL-10 release were more pronounced as the concentration of ATP was higher (Figure $1 \mathrm{~A}$ and $B$ ).
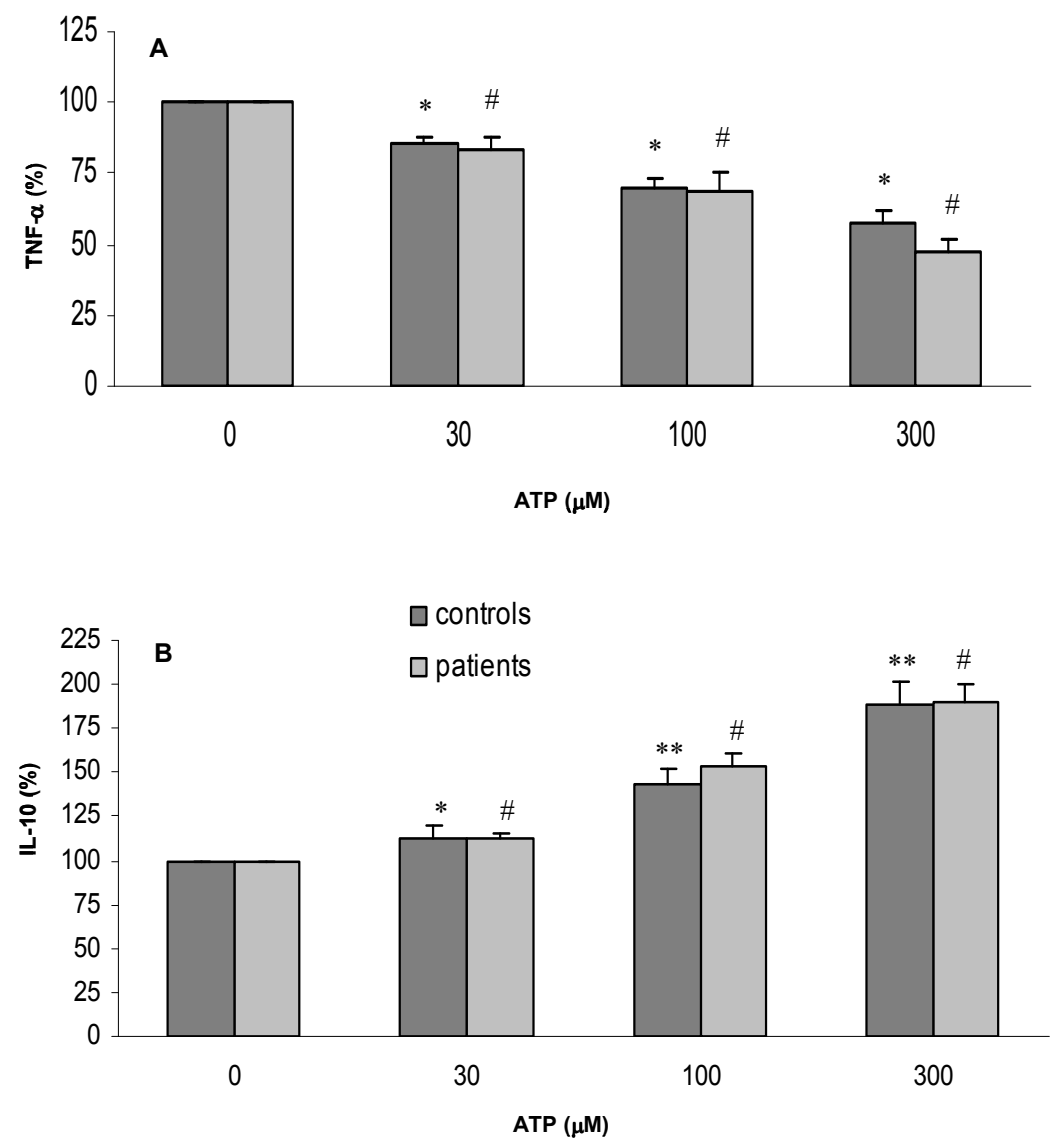

Figure 1 A/B: Modulating effect of ATP $(30,100$ and $300 \mu \mathrm{M})$ on LPS-PHA-induced TNF- $\alpha$ (A) and IL-10 (B) production in NSCLC patients compared to their matched controls. Results are expressed in percentage, with $100 \%$ representing the cytokine release under stimulation by LPS and PHA in the absence of ATP. Data are expressed as mean \pm SEM, ${ }^{*} P<0.01$ in the control group versus the incubation containing no ATP (panel A); ${ }^{\#}<<0.01$ in the patient group versus the incubating containing no ATP (panel $\mathrm{A}$ and $\mathrm{B}$ ), ${ }^{*} \mathrm{P}<0.05$ and ${ }^{* *} \mathrm{P}<0.01$ in the control group versus the incubation containing no ATP (panel B). 
As shown in figure $2 \mathrm{~A}$, the response of TNF- $\alpha$ to $300 \mu \mathrm{M}$ ATP seemed to be stronger in the cancer group compared to the control group (the slopes in figure $2 \mathrm{~A}$ indicate that on average, $300 \mu \mathrm{M}$ ATP reduces the TNF- $\alpha$ production in patients with $47 \%$ and in controls with $40 \%$ ). The correlation also indicates a stronger inhibitory effect of ATP as the basal inflammation is higher. For IL-10, only in the patient group a significant correlation was found between the stimulatory effect of ATP $(300 \mu \mathrm{M})$ on IL-10 and initial IL-10 levels (Figure 2B).
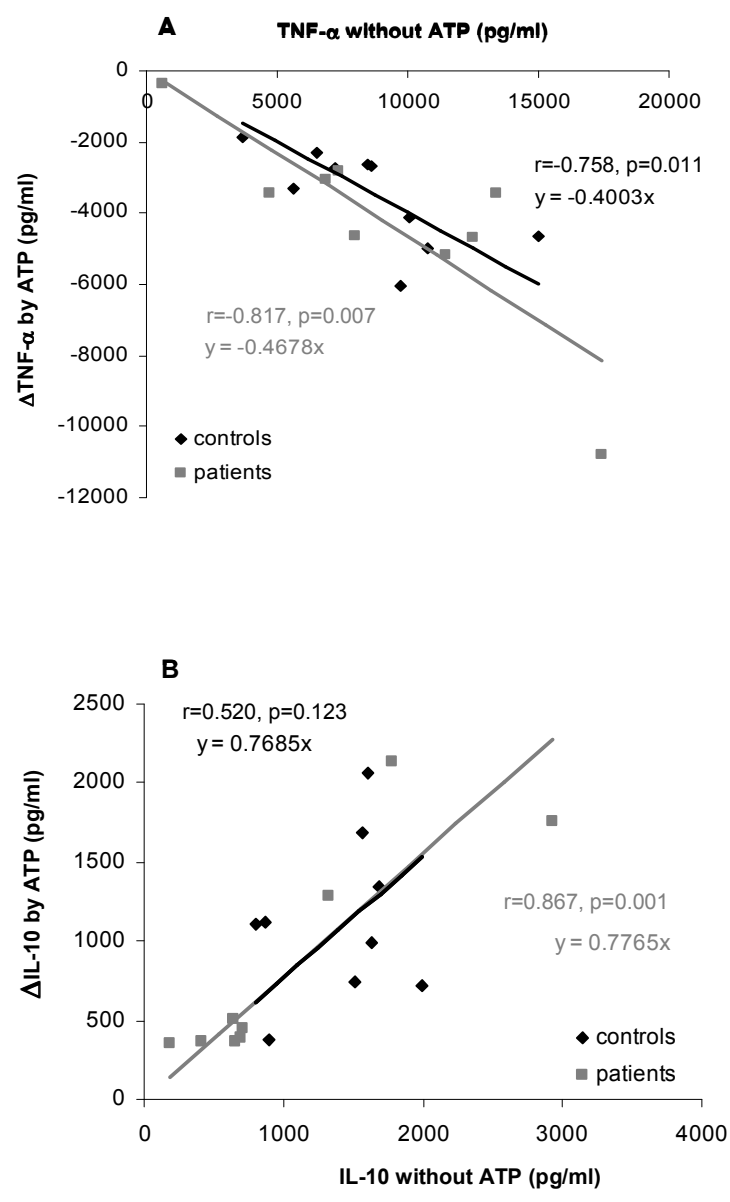

Figure 2 A/B: Effect of ATP $(300 \mu \mathrm{M})$ on LPS-PHA-induced TNF- $\alpha$ (A) and IL-10 (B) production in both NSCLC patients and their matched controls. The decrease and increase in LPS-PHA-induced TNF- $\alpha(A)$ and IL-10 (B) production respectively caused by ATP (Y-axis) is plotted against the LPSPHA-induced TNF- $\alpha$ (A) or IL-10 (B) production in the absence of ATP (X-axis). Data are expressed as individual values ( $n=10$ for the patients; $n=12$ for the controls). 


\section{Discussion}

ROS and free radicals are known to be involved in the process of carcinogenesis, as recently reviewed by Valko et al. [14]. Since little is known about the presence of oxidative stress in patients with progressive cancer, the first aim of our study was to determine the oxidative stress status in NSCLC patients compared to healthy individuals, matched for age, gender and smoking behaviour. Results showed a significant reduction in GPx activity and a significant increase in MDA levels and GST activity in NSCLC patients, compared to healthy controls. MDA is a marker of lipid peroxidation and this process is one of the reactions set into motion as a consequence of the formation of free radicals in cells and tissue. GPx is a primary antioxidant enzyme, since it is involved in the direct elimination of ROS, while GST, a secondary antioxidant enzyme, helps in the detoxification of ROS by decreasing peroxide levels. The data reported in the literature on antioxidant enzymes in different human cancer types are controversial. Our findings are different from Ho et al. [29] who showed an increase in GPx activity in NSCLC patients, however, the lack of matching for age en gender between the patients and healthy subjects is a limiting factor of that study. Kaynar et al. [30] did not find a different GPx activity in NSCLC and SCLC patients compared to a control group. However, our findings are consistent with several studies which showed that GPx was lowered in erythrocytes of cancer patients with advanced-stage tumours at different sites [31-33], in oesophageal and gastric cancer patients [34] and in serum of chronic lymphocytic leukemia patients [35]. Kaynar et al. [30] showed that MDA levels were increased in NSCLC and SCLC patients, and higher MDA levels were also observed in cancer patients with different tumour types with metastases [33], chronic lymphocytic leukemia [35] and patients with oesophageal and gastric cancer [34]. Slightly, but not significantly higher levels of GST activity, were observed in NSCLC and SCLC patients compared to controls [30]. Total antioxidant status, a marker comparable to the TEAC, and the activity of GR in serum of advanced stage cancer patients was, like in our study, also not different compared to controls [35]. In our study, patients and controls were matched for their smoking history (package years), indicating that the observed decrease in GPx activity and increase in MDA levels and GST activity were not caused by a different smoking history. Thus, the lower GPx activity and the higher MDA found in the cancer patient group are consistent with the elevated production of ROS present in NSCLC. This phenomenon is referred to as oxidative stress, which can cause serious oxidative damage to biological macromolecules like DNA, lipids and proteins.

To evaluate of the inflammatory status in NSCLC patients, basal levels of the proinflammatory cytokine TNF- $\alpha$, the anti-inflammatory cytokine IL-10, the positive acute phase proteins, CRP and haptoglobin, and the negative acute phase response proteins, albumin and pre-albumin, were measured. TNF- $\alpha$ was chosen because this cytokine has been implicated in cancer related side effects such as 
cachexia and fatigue [9-13]. Moreover, TNF- $\alpha$ is capable of activating nuclear factor kappaB $(\mathrm{NF} \kappa \mathrm{B})$ and activator protein-1 (AP-1) that will subsequently enhance other inflammatory mediators such as IL-8 and TNF- $\alpha$ itself, thereby amplifying the TNF$\alpha$-mediated inflammatory processes $[36,37]$. Our study shows that basal plasma TNF- $\alpha$ levels were significantly increased in NSCLC patients compared to healthy controls. This finding is consistent with previous studies in newly diagnosed NSCLC patients [38], advanced-stage NSCLC patients [39] and in advanced stage cancer patients with tumours at different sites [31, 32]. Moreover, we showed that levels of albumin, a negative acute phase protein, were significantly lower in NSCLC patients compared to controls. We found no changes in the basal levels of the antiinflammatory cytokine IL-10 between the NSCLC and the control group.

The subgroup of patients with chemotherapy pretreatment showed lower levels of pre-albumin and tended to display lower levels of GSH and TEAC, and higher levels of GSSG than the subgroup of patients without prior chemotherapy, suggesting that chemotherapy may have contributed to inflammation and oxidative stress in these patients. Patients with advanced NSCLC (stage IIIA-B/IV) showed lower levels of albumin and a higher ESR compared to early stages (stage I/II) NSCLC patients, indicating that the level of inflammation may be related to the severity of the disease. However, the number of patients in these subgroups are small and thus these results require confirmation in a larger population.

Since we showed earlier that the natural compound ATP has anti-inflammatory properties in LPS-PHA-stimulated blood of healthy subjects, we compared the antiinflammatory potential of ATP on induced inflammation in blood of controls and NSCLC patients. This stimulated blood model reflects the in vivo condition because all the cell-to-cell interactions are preserved and all blood components are present in in vivo ratios with non-cellular components [40]. In both the NSCLC and the control group, incubation with ATP significantly reduced LPS-PHA-induced TNF- $\alpha$ release and increased IL-10 release. These effects were dose-dependent and could already be achieved at $30 \mu \mathrm{M}$ of ATP. It is noteworthy that the anti-inflammatory effect of ATP was directly proportional to the level of induced inflammation both for TNF- $\alpha$ and IL-10, indicating that ATP may be especially effective in situations of marked inflammation.

The observed ex vivo anti-inflammatory effects of ATP in blood from NSCLC patients may partly explain the favourable effects of ATP on appetite, weight, muscle strength, fatigue and physical and functional quality of life, which were shown in a randomized clinical trial of NSCLC patients receiving ATP infusions compared to a control group of patients receiving usual palliative care only. Moreover, albumin levels remained stable in the ATP-treated group, whereas they decreased in the control group [18-20]. Besides these anti-inflammatory properties, ATP is also known to have in vitro anti-tumour effects via P2 receptors, as recently reviewed by White et al. [41]. 
In conclusion, our study shows an impaired antioxidant system in NSCLC patients, as shown by decreased levels of GPx activity and increased levels of MDA and GST activity, and enhanced inflammation as indicated by increased levels of TNF- $\alpha$ and decreased levels of albumin. Furthermore, the natural compound ATP shows significant anti-inflammatory effects in ex vivo stimulated blood of patients which are directly proportional to the degree of inflammation. Further research will be necessary to confirm these favourable anti-inflammatory effects of ATP in cancer patients in vivo. 


\section{References}

1 Parkin D.M., Bray F., Ferlay J. and Pisani P. Global cancer statistics, 2002. CA Cancer J Clin 2005; 55: 74-108.

2 Doll R., Peto R., Boreham J. and Sutherland I. Mortality in relation to smoking: 50 years' observations on male British doctors. Bmj 2004; 328: 1519.

3 Pirozynski M. 100 years of lung cancer. Respir Med 2006.

4 Mountain C.F. The international system for staging lung cancer. Semin Surg Oncol 2000; 18: 106-115.

5 de Visser K.E., Eichten A. and Coussens L.M. Paradoxical roles of the immune system during cancer development. Nat Rev Cancer 2006; 6: 24-37.

6 Marx J. Cancer research. Inflammation and cancer: the link grows stronger. Science 2004; 306: 966-968.

7 Karin M. NF-kappaB and cancer: mechanisms and targets. Mol Carcinog 2006; 45: 355-361.

8 Karin M. Nuclear factor-kappaB in cancer development and progression. Nature 2006; 441: 431-436.

9 Gutstein H.B. The biologic basis of fatigue. Cancer 2001; 92: 1678-1683.

10 von Haehling S., Genth-Zotz S., Anker S.D. and Volk H.D. Cachexia: a therapeutic approach beyond cytokine antagonism. Int J Cardiol 2002; 85: 173-183.

11 Kurzrock R. The role of cytokines in cancer-related fatigue. Cancer 2001; 92: 1684-1688.

12 Moldawer L.L., Rogy M.A. and Lowry S.F. The role of cytokines in cancer cachexia. JPEN J Parenter Enteral Nutr 1992; 16: 43S-49S.

13 Sharma R. and Anker S.D. Cytokines, apoptosis and cachexia: the potential for TNF antagonism. Int J Cardiol 2002; 85: 161-171.

14 Valko M., Rhodes C.J., Moncol J., Izakovic M. and Mazur M. Free radicals, metals and antioxidants in oxidative stress-induced cancer. Chem Biol Interact 2006; 160: 1-40.

15 Oberley T.D. and Oberley L.W. Antioxidant enzyme levels in cancer. Histol Histopathol 1997; 12: 525-535.

16 Szatrowski T.P. and Nathan C.F. Production of large amounts of hydrogen peroxide by human tumour cells. Cancer Res 1991; 51: 794-798.

17 Swennen E.L., Bast A. and Dagnelie P.C. Immunoregulatory effects of adenosine 5'triphosphate on cytokine release from stimulated whole blood. Eur J Immunol 2005; 35: 852858.

18 Agteresch H.J., Dagnelie P.C., van der Gaast A., Stijnen T. and Wilson J.H. Randomized clinical trial of adenosine 5'-triphosphate in patients with advanced non-small-cell lung cancer. J Natl Cancer Inst 2000; 92: 321-328.

19 Agteresch H.J., Burgers S.A., van der Gaast A., Wilson J.H. and Dagnelie P.C. Randomized clinical trial of adenosine 5'-triphosphate on tumour growth and survival in advanced lung cancer patients. Anticancer Drugs 2003; 14: 639-644.

20 Agteresch H.J., Rietveld T., Kerkhofs L.G., van den Berg J.W., Wilson J.H. and Dagnelie P.C. Beneficial effects of adenosine triphosphate on nutritional status in advanced lung cancer patients: a randomized clinical trial. $J$ Clin Oncol 2002; 20: 371-378.

21 Schweinsberg P.D. and Loo T.L. Simultaneous analysis of ATP, ADP, AMP, and other purines in human erythrocytes by high-performance liquid chromatography. J Chromatogr 1980; 181: 103-107.

22 Fischer M.A., Gransier T.J., Beckers L.M., Bekers O., Bast A. and Haenen G.R. Determination of the antioxidant capacity in blood. Clin Chem Lab Med 2005; 43: 735-740. 
23 Lux O., Naidoo D. and Salonikas C. Improved HPLC method for the simultaneous measurement of allantoin and uric acid in plasma. Ann Clin Biochem 1992; 29 ( Pt 6): 674675.

24 Lepage G., Munoz G., Champagne J. and Roy C.C. Preparative steps necessary for the accurate measurement of malondialdehyde by high-performance liquid chromatography. Anal Biochem 1991; 197: 277-283.

25 Vandeputte C., Guizon I., Genestie-Denis I., Vannier B. and Lorenzon G. A microtiter plate assay for total glutathione and glutathione disulfide contents in cultured/isolated cells: performance study of a new miniaturized protocol. Cell Biol Toxicol 1994; 10: 415-421.

26 Paglia D.E. and Valentine W.N. Studies on the quantitative and qualitative characterization of erythrocyte glutathione peroxidase. J Lab Clin Med 1967; 70: 158-169.

27 McCormick $\mathrm{D}$. Method for the determination of erythrocyte glutathion reductase activity. Tietz NM, editor. Textbook of clinical chemistry. Philadelphia: WB Saunders Company 1986.

28 Habig W.H. and Jakoby W.B. Assays for differentiation of glutathione S-transferases. Methods Enzymol 1981; 77: 398-405.

29 Ho J.C., Chan-Yeung M., Ho S.P., Mak J.C., Ip M.S., Ooi G.C., Wong M.P., Tsang K.W. and Lam W.K. Disturbance of systemic antioxidant profile in non-small cell lung carcinoma. Eur Respir J 2006.

30 Kaynar H., Meral M., Turhan H., Keles M., Celik G. and Akcay F. Glutathione peroxidase, glutathione-S-transferase, catalase, xanthine oxidase, Cu-Zn superoxide dismutase activities, total glutathione, nitric oxide, and malondialdehyde levels in erythrocytes of patients with small cell and non-small cell lung cancer. Cancer Lett 2005; 227: 133-139.

31 Mantovani G., Maccio A., Madeddu C., Mura L., Gramignano G., Lusso M.R., Mulas C., Mudu M.C., Murgia V., Camboni P., Massa E., Ferreli L., Contu P., Rinaldi A., Sanjust E., Atzei D. and Elsener B. Quantitative evaluation of oxidative stress, chronic inflammatory indices and leptin in cancer patients: correlation with stage and performance status. Int J Cancer 2002; 98: 84-91.

32 Mantovani G., Maccio A., Madeddu C., Mura L., Massa E., Gramignano G., Lusso M.R., Murgia V., Camboni P. and Ferreli L. Reactive oxygen species, antioxidant mechanisms and serum cytokine levels in cancer patients: impact of an antioxidant treatment. $J$ Cell Mol Med 2002; 6: 570-582.

33 Guven M., Ozturk B., Sayal A., Ozeturk A. and Ulutin T. Lipid peroxidation and antioxidant system in the blood of cancerous patients with metastasis. Cancer Biochem Biophys 1999; 17: $155-162$.

34 Dursun H., Bilici M., Uyanik A., Okcu N. and Akyuz M. Antioxidant enzyme activities and lipid peroxidation levels in erythrocytes of patients with oesophageal and gastric cancer. $J$ Int Med Res 2006; 34: 193-199.

35 Bakan N., Taysi S., Yilmaz O., Bakan E., Kuskay S., Uzun N. and Gundogdu M. Glutathione peroxidase, glutathione reductase, Cu-Zn superoxide dismutase activities, glutathione, nitric oxide, and malondialdehyde concentrations in serum of patients with chronic lymphocytic leukemia. Clin Chim Acta 2003; 338: 143-149.

36 Rahman I. Oxidative stress, transcription factors and chromatin remodelling in lung inflammation. Biochem Pharmacol 2002; 64: 935-942.

37 Rahman I. and MacNee W. Role of transcription factors in inflammatory lung diseases. Thorax 1998; 53: 601-612.

38 Kayacan O., Karnak D., Beder S., Gullu E., Tutkak H., Senler F.C. and Koksal D. Impact of TNF-alpha and IL-6 levels on development of cachexia in newly diagnosed NSCLC patients. Am J Clin Oncol 2006; 29: 328-335. 
39 Tas F., Duranyildiz D., Argon A., Oguz H., Camlica H., Yasasever V. and Topuz E. Serum levels of leptin and proinflammatory cytokines in advanced-stage non-small cell lung cancer. Med Oncol 2005; 22: 353-358.

40 Yaqoob P., Newsholme E.A. and Calder P.C. Comparison of cytokine production in cultures of whole human blood and purified mononuclear cells. Cytokine 1999; 11: 600-605.

41 White N. and Burnstock G. P2 receptors and cancer. Trends Pharmacol Sci 2006; 27: 211217. 
General discussion 
Chapter 8 


\section{General discussion}

The data presented in this thesis show that adenosine 5'-triphosphate (ATP) possesses ex vivo anti-inflammatory properties through simultaneous inhibition of the pro-inflammatory response and stimulation of the anti-inflammatory response. This concerted modulation by ATP is mediated via activation of different purinergic receptors: $\mathrm{P}_{2} \mathrm{Y}_{11}$ is involved in the inhibitory effect of ATP on tumour necrosis factoralpha (TNF- $\alpha$ ) and P2Y 12 is responsible for the stimulatory effect of ATP on interleukin (IL)-10. Moreover, these anti-inflammatory effects of ATP persist under circumstances of severe oxidative stress. In addition, ATP is able to modulate oxidative stress directly by scavenging hydroxyl radicals $\left(\mathrm{OH}^{\circ}\right)$ in vitro. The antiinflammatory effects of ATP are, besides in blood from healthy subjects, also observed in blood from non-small-cell lung cancer (NSCLC) patients, who showed an elevated inflammatory and oxidative stress status. Additionally, ATP is able to protect normal blood cells against ex vivo radiation-induced damage by different simultaneous mechanisms: (i) via its concerted anti-inflammatory effects, (ii) via its DNA damage-inhibiting effects and (iii) by restoration of decreased glutathione (GSH) levels.

Several aspects of this thesis merit further discussion and therefore, in the next paragraphs, the following topics will be discussed:

- advantages of the model used

- comparison of the favourable effects of ATP with other compounds

- the mechanism of action of ATP

- the link of the findings of this thesis with the in vivo situation, and some ideas for possible further research.

The present thesis mainly focuses on an ex vivo inflammation model, which approaches the in vivo situation more than most in vitro studies. This contrasts with most in vitro studies, which are performed in isolated cell lines. In order to investigate both the modulatory effects of ATP on inflammation in the absence and presence of oxidative stress and the radioprotective effects of ATP, we used human whole blood treated either with lipopolysaccharide (LPS) and phytohemagglutinin $(\mathrm{PHA})$, which are stimulators of cytokine production, or with gamma-radiation. The advantage of the stimulated blood model is that all cell types including lymphocytes, monocytes, neutrophils, granulocytes and platelets are present in their natural occurring ratios and are able to produce cytokines. Moreover, the natural cell-to-cell interactions are preserved and all blood components are present in in vivo ratios with non-cellular components. Therefore, this system is a better reflection of the physiological environment and forms an appropriate and reproducible culture condition to measure stimulation-induced damage ex vivo. 
The property of ATP in this stimulated blood model to simultaneously modulate the pro- and anti-inflammatory response, i.e. the TNF- $\alpha$ suppressing and IL-10 stimulating activity of ATP, is remarkable. TNF- $\alpha$ is known to activate nuclear factor kappaB $\left(\mathrm{NF}_{\kappa \mathrm{B}}\right)$, thereby activating the production of other cytokines and amplifying its own synthesis, and to induce oxidative stress by reactive oxygen species (ROS) production by immune cells [1, 2]. In contrast, the anti-inflammatory cytokine IL-10 is known to inhibit the release of pro-inflammatory cytokines, inflammation-mediated ROS production and ROS-mediated NFKB activation [3, 4]. Therefore, the inhibition of TNF- $\alpha$ and the increase of IL-10 by ATP will attenuate not only inflammation, but also oxidative stress. Kaur et al. [5] recently showed the importance of the interplay of IL-10 and TNF- $\alpha$ to protect against increased oxidative stress in isolated adult cardiac myocytes. Therefore, in any clinical condition, an appropriate balance between IL-10 and TNF- $\alpha$ may be of crucial importance for mitigating oxidative stress. Besides ATP, there are only a limited number of compounds known which display the same concerted modulation on TNF- $\alpha$ and IL-10 release. For example, cyclosporine was able to induce TNF- $\alpha$ suppression and IL-10 stimulation in fibroblast-like synoviocytes [6]. However, whereas the inhibitory effect on TNF- $\alpha$ by cyclosporine was directly dependent on the IL-10 increase, this was not the case for ATP: in our used stimulated blood model, the effects of ATP on TNF- $\alpha$ and IL-10 were independent and mediated by different receptors. In addition, of the ATPmetabolites tested in the stimulated blood model, only adenosine 5'-diphosphate (ADP) showed a similar concerted modulation as ATP on TNF- $\alpha$ and IL-10 release, indicating that among $\mathrm{P} 1 / \mathrm{P} 2$ purinergic compounds, this combined effect is an unique effect of ATP and ADP.

As mentioned above, the activity of ATP on TNF- $\alpha$ and IL-10 was shown to be regulated via the activation of different purinergic receptors. The $\mathrm{P}_{2} \mathrm{Y}_{11}$ receptor, which was responsible for the inhibition of TNF- $\alpha$ by ATP, is dually coupled to adenylyl cyclase (AC) activation and phospholipase $C$ (PLC) activation [7-9], whereas the $P 2 Y_{12}$ receptor, which was involved in the stimulatory effect of ATP on $\mathrm{IL}-10$ release, is coupled to $A C$ inhibition [7]. Among the $P 2 Y$ receptors, $P 2 Y_{11}$ is the only ATP-specific receptor [7], indicating that the inhibitory effect of ATP on TNF- $\alpha$ was an effect of ATP itself. $P 2 Y_{12}$ prefers ADP, which indicates that the stimulatory effect of ATP on IL-10 was due to its breakdown product ADP.

The differential effects of ATP on TNF- $\alpha$ and IL-10 were, besides in LPS-PHAinduced inflammation, also present in radiation-induced inflammation. As expected, the inhibitory effect of ATP on radiation-induced TNF- $\alpha$ release was mediated via $\mathrm{P}_{2 Y_{11}}$ receptor activation. However, quite unexpectedly, simultaneous incubation with a selective $P 2 Y_{12}$ receptor antagonist did not reverse the stimulatory effect of ATP on radiation-induced IL-10 release. One potential cause of this may be that the $\mathrm{P}_{2} \mathrm{Y}_{12}$ receptor, or its transduction system, was possibly damaged by radiation. As reviewed by Van der Vliet et al. [10], oxidative stress can affect the binding of 
ligands to membrane receptors, such as beta-adrenergic receptors and muscarinic receptors, as well as the coupling of receptors to G-proteins or the second messengers. Moreover, Kramer et al. [11] showed in rat airways that the adrenergic receptor, which is coupled to $A C$, is more susceptible to ROS than the muscarinic response, which is coupled to PLC. Based on this, we speculate that the P2Y 12 receptor, which is coupled to $G_{i}$ and thereby inhibiting $A C$ [7], may be more sensitive to radiation compared to the $\mathrm{P}_{2} \mathrm{Y}_{11}$ receptor, which has the unique property of being dually coupled to $G_{q}$, thereby activating the PLC pathway, and to $G_{s}$, which leads to $A C$ activation [7, 9]. Another possible explanation could be that a different P2Y receptor is involved in the stimulatory effect of ATP on radiation-induced IL-10 release than in the stimulatory effect of ATP on LPS-PHA-induced IL-10 release. It is also possible that IL-10 is not yet maximally expressed at the measured timepoint $(6 \mathrm{~h})$ after irradiation, and that consequently the stimulatory effect of ATP on IL-10 release would be higher at later time-points after irradiation. The additional observed radioprotective effects of ATP, by inhibiting DNA damage and restoring decreased GSH levels, would suggest that ATP may protect normal blood cells against damage induced by radiotherapy, which in the in vivo situation could lead to the prevention of fever, radiation-induced side effects or complications. The protection of ATP against ROS-induced damage could be explained by the $\mathrm{OH}^{\circ}$ scavenging effect of ATP, as shown in chapter 3.

The ex vivo anti-inflammatory effects of ATP, which were demonstrated in different experiments in this thesis, are consistent with the earlier shown favourable clinical effects of ATP on nutritional status and overall quality of life in a randomized clinical trial in patients with NSCLC [12-14]. Results of that study showed that albumin levels remained stable in the ATP-treated group, whereas they decreased in the control group. Moreover, data in a subgroup of patients suggested potential inhibition of C-reactive protein by ATP. In the present thesis, we confirm the presence of a higher inflammatory status, in a pilot study, in NSCLC patients, compared to a control group matched for gender, age and smoking history. The presence of a chronic pro-inflammatory state has been implicated in the etiology of cancer-related complications such as progressive weight loss and fatigue [15-18]. Thus, our data confirm ATP as a promising approach in the supportive treatment of cancer-related side effects, an effect which appears to be at least partially mediated via its anti-inflammatory properties. Clinical trials with ATP will have to further corroborate the anti-inflammatory and radioprotective properties of ATP in vivo.

The potential application of ATP in cancer has aroused interest due to its favourable activities such as (a) inhibition of tumour growth in vitro and in mice in vivo [19-25], (b) increasing the passive permeability of several chemotherapeutic agents in vitro and in mice in vivo [26-29] and (c) rendering cancer cells more sensitive for radiation damage by decreasing $\mathrm{GSH}$ levels in tumour cells but not in normal cells in vitro [30]. It should be noted that in the present study, the focus was on normal 
blood cells; therefore similar types of experiments in different cancer cell lines would be valuable. Generally speaking, a good radioprotector should protect normal cells, but afford no protection under a hypoxic environment, which is a common feature in solid tumours.

The fact that ATP exerts most of its favourable effects via activation of different purinergic receptors would suggest that ATP may be superior to selective receptor agonists in supportive cancer treatment. For example, in comparison with ATP, a selective $P 2 Y_{11}$ receptor agonist would only inhibit TNF- $\alpha$ release but will not exert the concerted modulation on different cytokines as induced by ATP, and is unlikely to have similar radioprotective effects as ATP. Moreover, when compared with a selective $\mathrm{P}_{2} \mathrm{Y}_{11}$ receptor agonist, ATP will have additional beneficial effects via several purinergic receptors, first by its direct stimulation of $P 2 Y_{11}$ and $P 2 Y_{2}$ receptors, and second, via its degradation to $A D P$ on $P 2 Y_{1}, P 2 Y_{12}$ an $P 2 Y_{13}$ receptors. For example, stimulation of appetite, which is known to be regulated via the $P 2 Y_{1}$ receptor [31], can be triggered by ATP via its degradation to ADP, but this effect cannot be achieved by a selective $\mathrm{P}_{2} \mathrm{Y}_{11}$ receptor agonist.

When compared with ATP, corticosteroids and non-steroidal anti-inflammatory drugs (NSAIDs), which have appetite stimulating and anti-inflammatory activities, did not have any effect on weight loss in cancer patients [32-35]. TNF- $\alpha$ blockers, such as infliximab (Remicade $\AA$ ), etanercept (Enbrel ${ }^{\circledR}$ ) and adalimumab (Humira $®$ ) are effective therapeutic agents used in routine clinical practice for severe rheumatologic and chronic inflammatory conditions [36, 37]. However, these compounds modulate only TNF- $\alpha$, are expensive, and the in vivo use has been associated with an increased rate of side effects [38, 39]. Compared to ATP, synthetic radioprotectors, which so far have mostly failed in clinical practice due to their acute toxicity [40], lack the concerted anti-inflammatory effects of ATP and are known to have acute side effects. Due to the combined favourable effects of ATP in relation to cancer, ATP would appear to be a promising agent to improve therapy and quality of life of cancer patients.

Placebo-controlled clinical trials with ATP in patients with different types of cancer, treated with chemotherapy and/or radiotherapy, will be needed to confirm the antiinflammatory effects of ATP and to expand our knowledge by directly measuring the effect of ATP on tumour growth and survival. It also may be valuable to investigate the effect of ATP in other diseases related to oxidative stress and/or inflammation, such as chronic obstructive pulmonary disease (COPD), asthma, and rheumatoid arthritis (RA), as well as diseases associated with weight loss and impaired quality of life, such as COPD, chronic heart failure and acquired immune deficiency syndrome (AIDS). Currently, we are performing a double-blind randomized placebocontrolled clinical trial aimed at assessing the effect of ATP infusions on nutritional status and quality of life in NSCLC patients selected for radiotherapy, while at the 
same time evaluating the potential of ATP to prevent short and long term effects of radiotherapy, including intermediate markers of inflammation and oxidative stress, as well as the potential of ATP to inhibit tumour growth and to improve survival. 


\section{References}

1 Rahman I. and MacNee W. Role of transcription factors in inflammatory lung diseases. Thorax 1998; 53: 601-612.

2 Rahman I. Oxidative stress, transcription factors and chromatin remodelling in lung inflammation. Biochem Pharmacol 2002; 64: 935-942.

3 Dokka S., Shi X., Leonard S., Wang L., Castranova V. and Rojanasakul Y. Interleukin-10mediated inhibition of free radical generation in macrophages. Am J Physiol Lung Cell Mol Physiol 2001; 280: L1196-1202.

4 Selzman C.H., Shames B.D., Miller S.A., Pulido E.J., Meng X., Mclntyre R.C., Jr. and Harken A.H. Therapeutic implications of interleukin-10 in surgical disease. Shock 1998; 10: 309-318.

5 Kaur K., Sharma A.K., Dhingra S. and Singal P.K. Interplay of TNF-alpha and IL-10 in regulating oxidative stress in isolated adult cardiac myocytes. $J$ Mol Cell Cardiol 2006; 41: 1023-1030.

6 Cho M.L., Kim W.U., Min S.Y., Min D.J., Min J.K., Lee S.H., Park S.H., Cho C.S. and Kim H.Y. Cyclosporine differentially regulates interleukin-10, interleukin-15, and tumour necrosis factor a production by rheumatoid synoviocytes. Arthritis Rheum 2002; 46: 42-51.

7 von Kugelgen I. and Wetter A. Molecular pharmacology of P2Y-receptors. Naunyn Schmiedebergs Arch Pharmacol 2000; 362: 310-323.

8 Communi D., Janssens R., Suarez-Huerta N., Robaye B. and Boeynaems J.M. Advances in signalling by extracellular nucleotides. the role and transduction mechanisms of P2Y receptors. Cell Signal 2000; 12: 351-360.

9 Communi D., Robaye B. and Boeynaems J.M. Pharmacological characterization of the human P2Y11 receptor. Br J Pharmacol 1999; 128: 1199-1206.

10 Van der Vliet A. and Bast A. Effect of oxidative stress on receptors and signal transmission. Chem Biol Interact 1992; 85: 95-116.

11 Kramer K., Doelman C.J., Timmerman H. and Bast A. A disbalance between beta-adrenergic and muscarinic responses caused by hydrogen peroxide in rat airways in vitro. Biochem Biophys Res Commun 1987; 145: 357-362.

12 Agteresch H.J., Burgers S.A., van der Gaast A., Wilson J.H. and Dagnelie P.C. Randomized clinical trial of adenosine 5'-triphosphate on tumour growth and survival in advanced lung cancer patients. Anticancer Drugs 2003; 14: 639-644.

13 Agteresch H.J., Dagnelie P.C., van der Gaast A., Stijnen T. and Wilson J.H. Randomized clinical trial of adenosine 5'-triphosphate in patients with advanced non-small-cell lung cancer. J Natl Cancer Inst 2000; 92: 321-328.

14 Agteresch H.J., Rietveld T., Kerkhofs L.G., van den Berg J.W., Wilson J.H. and Dagnelie P.C. Beneficial effects of adenosine triphosphate on nutritional status in advanced lung cancer patients: a randomized clinical trial. $J$ Clin Oncol 2002; 20: 371-378.

15 von Haehling S., Genth-Zotz S., Anker S.D. and Volk H.D. Cachexia: a therapeutic approach beyond cytokine antagonism. Int J Cardiol 2002; 85: 173-183.

16 Kurzrock R. The role of cytokines in cancer-related fatigue. Cancer 2001; 92: 1684-1688.

17 Moldawer L.L., Rogy M.A. and Lowry S.F. The role of cytokines in cancer cachexia. JPEN J Parenter Enteral Nutr 1992; 16: 43S-49S.

18 Sharma R. and Anker S.D. Cytokines, apoptosis and cachexia: the potential for TNF antagonism. Int J Cardiol 2002; 85: 161-171.

19 Agteresch H.J., Van Rooijen M., van den Berg J., Minderman-voortman G., Wilson J.H. and Dagnelie P.C. Growth inhibition of lung cancer cells by adenosine 5'-triphosphate. drug development research 2003; 60: 196-203. 
20 Yamada T., Okajima F., Akbar M., Tomura H., Narita T., Ohwada S., Morishita Y. and Kondo $Y$. Cell cycle arrest and the induction of apoptosis in pancreatic cancer cells exposed to adenosine triphosphate in vitro. Oncol Rep 2002; 9: 113-117.

21 Conigrave A.D., van der Weyden L., Holt L., Jiang L., Wilson P., Christopherson R.I. and Morris M.B. Extracellular ATP-dependent suppression of proliferation and induction of differentiation of human HL-60 leukemia cells by distinct mechanisms. Biochem Pharmacol 2000; 60: 1585-1591.

22 White N. and Burnstock G. P2 receptors and cancer. Trends Pharmacol Sci 2006; 27: 211 217.

23 Rapaport E. Experimental cancer therapy in mice by adenine nucleotides. Eur J Cancer Clin Oncol 1988; 24: 1491-1497.

24 Rapaport E. Mechanisms of anticancer activities of adenine nucleotides in tumour-bearing hosts. Ann N Y Acad Sci 1990; 603: 142-149; discussion 149-150.

25 Lasso de la Vega M.C., Terradez P., Obrador E., Navarro J., Pellicer J.A. and Estrela J.M. Inhibition of cancer growth and selective glutathione depletion in Ehrlich tumour cells in vivo by extracellular ATP. Biochem J 1994; 298 ( Pt 1): 99-105.

26 Kitagawa T. and Akamatsu Y. Modulation of passive permeability by external ATP and cytoskeleton-attacking agents in cultured mammalian cells. Biochim Biophys Acta 1983; 734: 25-32.

27 Mure T., Sano K. and Kitagawa T. Modulation of membrane permeability, cell proliferation and cytotoxicity of antitumour agents by external ATP in mouse tumour cells. Jpn J Cancer Res 1992; 83: 121-126.

28 Hatta Y., Takahashi M., Enomoto Y., Takahashi N., Sawada U. and Horie T. Adenosine triphosphate (ATP) enhances the antitumour effect of etoposide (VP16) in lung cancer cells. Oncol Rep 2004; 12: 1139-1142.

29 Obrador E., Navarro J., Mompo J., Asensi M., Pellicer J.A. and Estrela J.M. Glutathione and the rate of cellular proliferation determine tumour cell sensitivity to tumour necrosis factor in vivo. Biochem J 1997; 325 ( Pt 1): 183-189.

30 Estrela J.M., Obrador E., Navarro J., Lasso De la Vega M.C. and Pellicer J.A. Elimination of Ehrlich tumours by ATP-induced growth inhibition, glutathione depletion and X-rays. Nat Med 1995; 1: 84-88.

31 Kittner H., Franke H., Harsch J.I., El-Ashmawy I.M., Seidel B., Krugel U. and Illes P. Enhanced food intake after stimulation of hypothalamic $\mathrm{P} 2 \mathrm{Y}$ receptors in rats: modulation of feeding behaviour by extracellular nucleotides. Eur J Neurosci 2006; 24: 2049-2056.

32 Willox J.C., Corr J., Shaw J., Richardson M., Calman K.C. and Drennan M. Prednisolone as an appetite stimulant in patients with cancer. Br Med J (Clin Res Ed) 1984; 288: 27.

33 Popiela T., Lucchi R. and Giongo F. Methylprednisolone as palliative therapy for female terminal cancer patients. The Methylprednisolone Female Preterminal Cancer Study Group. Eur J Cancer Clin Oncol 1989; 25: 1823-1829.

34 Bruera E., Roca E., Cedaro L., Carraro S. and Chacon R. Action of oral methylprednisolone in terminal cancer patients: a prospective randomized double-blind study. Cancer Treat Rep 1985; 69: 751-754.

35 Lundholm K., Gelin J., Hyltander A., Lonnroth C., Sandstrom R., Svaninger G., Korner U., Gulich M., Karrefors I., Norli B. and et al. Anti-inflammatory treatment may prolong survival in undernourished patients with metastatic solid tumours. Cancer Res 1994; 54: 5602-5606.

36 Reimold A.M. New indications for treatment of chronic inflammation by TNF-alpha blockade. Am J Med Sci 2003; 325: 75-92.

37 Atzeni F., Sarzi-Puttini P., Doria A., laccarino L. and Capsoni F. Potential off-label use of infliximab in autoimmune and non-autoimmune diseases: a review. Autoimmun Rev 2005; 4: $144-152$. 
38 Crum N.F., Lederman E.R. and Wallace M.R. Infections associated with tumour necrosis factor-alpha antagonists. Medicine (Baltimore) 2005; 84: 291-302.

39 Bakleh M., Tleyjeh I., Matteson E.L., Osmon D.R. and Berbari E.F. Infectious complications of tumour necrosis factor-alpha antagonists. Int J Dermatol 2005; 44: 443-448.

40 Nair C.K., Parida D.K. and Nomura T. Radioprotectors in radiotherapy. J Radiat Res (Tokyo) 2001; 42: 21-37. 
Summary

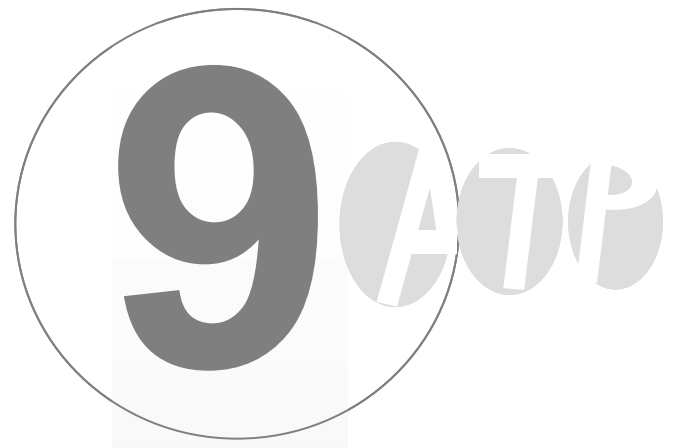


Chapter 9 


\section{Summary}

Adenosine 5'-triphosphate (ATP), a naturally occurring nucleotide, is found in every cell of the human body and is well-known for its central role in intracellular energy metabolism. In addition, ATP is widely distributed outside the cell, influencing many biological processes such as muscle contraction and neurotransmission, through signal transduction via purinergic receptors. In a randomized clinical trial, favourable effects of ATP were shown in patients with advanced non-small-cell lung cancer (NSCLC). In these patients, regular intravenous infusions of ATP improved muscle strength, fatigue, appetite, body weight and functional quality of life.

Cancer is known to be associated with inflammation and oxidative stress; fatigue and weight loss, which are frequent secondary symptoms of cancer, are thought to be due to the production of pro-inflammatory cytokines. Moreover, radiotherapy, as one of the main options for treatment of cancer, also causes oxidative stress and damage to healthy tissue, thereby inducing clinical side effects. To avoid radiationinduced complications, protection of healthy tissue is of major importance.

Therefore, the present thesis was aimed at:

1. Revealing a possible mechanism behind the in vivo favourable effects of ATP on nutrition and overall quality of life in cancer patients by focusing on the modulatory effects of ATP on inflammation and oxidative stress;

2. Investigating the radioprotective effects of ATP in normal cells

The following specific study questions were formulated:

- Is ATP a modulator of inflammation and oxidative stress?

- What are the underlying mechanisms for the modulatory effects of ATP on inflammation and oxidative stress?

- Is ATP able to protect normal cells against radiation-induced damage such as inflammation, oxidative stress and DNA damage?

In chapter 2, we examined the ex vivo immunomodulatory effects of ATP in whole blood from healthy subjects, i.e. a model closely resembling the in vivo situation. For this purpose, whole blood was incubated with lipopolysaccharide (LPS) and phytohemagglutinin (PHA), which are both inducers of cytokine production. Results showed that ATP, in a dose-dependent fashion, inhibited the ex vivo LPS-PHAinduced production of the pro-inflammatory cytokine tumour necrosis factor-alpha (TNF- $\alpha$ ) and stimulated the production of the anti-inflammatory cytokine interleukin (IL)-10. Adenosine 5'-O-(3-thiotriphosphate) (ATP $\gamma \mathrm{S}$ ), an ATP analogue, and adenosine 5'-diphosphate (ADP), a breakdown product of ATP, also inhibited TNF- $\alpha$ release, but only ADP showed a stimulatory effect on IL-10 release. Adenosine, a breakdown product of ATP, was not involved in the effect of ATP on TNF- $\alpha$ and IL- 
10 release. These data indicate that ATP is an anti-inflammatory agent with simultaneous TNF- $\alpha$ suppressing and IL-10 augmenting activity.

Cancer is, besides inflammation, also associated with oxidative stress. Therefore, in chapter 3, the anti-inflammatory effects of ATP were examined in the presence of oxidative stress, as simulated by the incubation of blood with different concentrations of hydrogen peroxide $\left(\mathrm{H}_{2} \mathrm{O}_{2}\right)$, prior to ATP and LPS-PHA incubation. Results showed that ATP retained its anti-inflammatory effects in the presence of severe oxidative stress. Moreover, ATP was able to scavenge hydroxyl radicals $\left(\mathrm{OH}^{\circ}\right)$, indicating a direct attenuation of oxidative stress by ATP itself.

The mechanism involved in the observed anti-inflammatory effects of ATP in LPSPHA-stimulated blood was investigated in chapter 4. This study was aimed at identifying the purinergic receptors involved in the anti-inflammatory effects of ATP by using several specific receptor agonists and antagonists. Results showed that the down-regulation of TNF- $\alpha$ by ATP was mediated by P $Y_{11}$ receptor activation, and the simultaneous up-regulation of $\mathrm{IL}-10$ by $\mathrm{P}_{2} \mathrm{Y}_{12}$ receptor activation. Thus, the concerted modulation of pro- and anti-inflammatory cytokines by ATP, is mediated by different purinergic receptors.

In chapter 5 we further characterized the LPS-PHA-stimulated whole blood model by investigating the breakdown profile of ATP in this model. In this ex vivo model, ATP is slowly broken down, probably due to lowered ecto-ezyme concentration in this diluted blood model. We also investigated the time-dependent effect of ATP and its metabolites on several inflammatory cytokines, induced at different time-points after LPS-PHA stimulation. ATP inhibited the LPS-PHA-induced TNF- $\alpha$, interferongamma (IFN- $\gamma$ ) and IL-1 $\beta$ production, but increased the production of IL-8 and IL-10. These effects of ATP were rapid (2, 4 and $6 \mathrm{~h}$ after LPS-PHA stimulation) and persisted until $24 \mathrm{~h}$ after stimulation. Metabolites of ATP did not mimic the effects of ATP, i.e. they showed either no, similar or opposite effects on cytokine release, selective to ATP. At $2 \mathrm{~h}$, but not at later time-points, ATP down-regulated the LPS$\mathrm{PHA}$-induced activation of the transcription factor nuclear factor kappaB (NFKB), suggesting an early inhibitory effect of ATP on NFKB.

As described in chapter 6 , the effects of ATP on radiation-induced damage after ex vivo irradiation of blood from healthy subjects are reported. Ex vivo irradiation of blood induced cytokine release, DNA damage and depletion of glutathione (GSH) levels. ATP inhibited radiation-induced TNF- $\alpha$ release and increased IL-10 release. Moreover, ATP attenuated radiation-induced DNA damage.

In chapter 7, the oxidative stress and inflammatory status of NSCLC patients and healthy control subjects matched for age, gender and smoking history were quantified. In addition, the ex vivo anti-inflammatory effects of ATP were examined in blood of NSCLC patients and controls. Results showed an impaired antioxidant system in the patient group compared to the matched control group, as shown by decreased levels of glutathione peroxidase (GPx) activity and increased levels of malondialdehyde (MDA) and glutathione-S-transferase (GST) activity; and an 
enhanced inflammation as indicated by increased levels of TNF- $\alpha$ and decreased levels of albumin. Furthermore, ATP showed anti-inflammatory effects in ex vivo stimulated blood, both in cancer patients and controls, which were directly proportional to the degree of inflammation.

Finally, in chapter $\mathbf{8}$, the main findings from the studies described in this thesis are discussed.

We conclude that the data of this thesis support the value of ATP as a highly potent natural compound, which is able to modulate inflammation and oxidative stress. Many of the demonstrated effects of ATP have not previously been reported, including the anti-inflammatory effects of ATP in ex vivo LPS-PHA-stimulated and radiation-treated blood, and the radioprotective effects of ATP on DNA damage in ex vivo radiated blood. Our experiments demonstrate that ATP, through an alteration of the balance among pro- and anti-inflammatory cytokines, possesses marked anti-inflammatory properties, via activation of different purinergic receptors, which persist even under circumstances of severe oxidative stress. Moreover, ATP is able to scavenge $\mathrm{OH}^{*}$ and to alleviate radiation-toxicity to blood cells by inhibiting radiation-induced inflammation and DNA damage. 



\section{Nederlandse samenvatting}

Adenosine 5'-trifosfaat (ATP), een natuurlijk voorkomend nucleotide, is aanwezig in iedere cel van het menselijk lichaam en is bekend voor zijn intracellulaire functie in energie metabolisme. Bovendien is ATP ook aanwezig buiten de cel en blijkt daar verschillende biologische processen te beïnvloeden zoals neurontransmissie en spiersamentrekking.

In een eerder uitgevoerde gerandomiseerde klinische studie zijn gunstige effecten van ATP aangetoond bij patiënten met vergevorderde niet-kleincellige longkanker. ATP infusen verbeterden de spierkracht, vermoeidheid, eetlust, lichaamsgewicht en levenskwaliteit bij deze patiënten.

Het is bekend dat kanker veelal geassocieerd is met ontsteking en oxidatieve stress. Ook is aangetoond dat vermoeidheid en gewichtsverlies, die veel voorkomende symptomen zijn bij kanker, veroorzaakt worden door de productie van ontstekingsbevorderende cytokines. Een veel gebruikte therapie voor kanker is bestraling, die naast kankercellen ook gezonde cellen beschadigt, hetgeen kan leiden tot bijwerkingen en complicaties. Om deze reden is het belangrijk om gezond weefsel te beschermen, waardoor bestralings-geïnduceerde complicaties vermeden kunnen worden.

Dit proefschrift heeft als doel:

1. Het mechanisme te onderzoeken dat verantwoordelijk is voor de in vivo aangetoonde gunstige effecten van ATP op de voedingstoestand en de kwaliteit van leven bij kankerpatiënten, met name de effecten van ATP bij ontsteking en oxidatieve stress;

2. Het onderzoeken van de beschermende effecten van ATP in normale cellen na bestraling

De volgende specifieke vraagstellingen werden geformuleerd:

- Is ATP een modulator van ontsteking en oxidatieve stress?

- Wat zijn de onderliggende mechanismen voor de modulatoire effecten van ATP bij ontsteking en oxidatieve stress?

- $\quad$ Kan ATP normale cellen beschermen tegen bestralings-geïnduceerd schade zoals ontsteking, oxidatieve stress en DNA schade?

In hoofdstuk 2 hebben we de ex vivo immunomodulatoire effecten van ATP onderzocht in het bloed van gezonde vrijwilligers om de in vivo situatie zoveel mogelijk na te bootsen. Voor dit onderzoek werd bloed geïncubeerd met lipopolysaccharide (LPS) en phytohemagglutinine (PHA), dit zijn stoffen die aanzetten tot de productie van cytokines. De resultaten laten zien dat ATP, op een dosis-afhankelijke wijze, de geïnduceerde productie van het ontstekingsbevorderende cytokine tumor necrose factor-alfa (TNF- $\alpha$ ) remt, en de 
productie van het ontstekingsremmende cytokine interleukin (IL)-10 stimuleert. Adenosine 5'-O-(3-thiotrifosfaat) (ATP $\gamma \mathrm{S})$, een ATP analoog, en adenosine 5'difosfaat (ADP), een afbraakproduct van ATP, remde eveneens de TNF- $\alpha$ productie, maar van deze stoffen was alleen ADP in staat om IL-10 te stimuleren. Adenosine, een afbraakproduct van ATP, was niet betrokken in het effect van ATP op de TNF- $\alpha$ en IL-10 productie. Deze resultaten geven aan dat ATP een ontstekingsremmende stof is met tegelijkertijd een TNF- $\alpha$ remmende en IL-10 stimulerende activiteit.

Omdat kanker, naast ontsteking, ook gerelateerd is aan oxidatieve stress, hebben we in hoofdstuk 3 de ontstekingsremmende effecten van ATP onderzocht in de aanwezigheid van oxidatieve stress, gesimuleerd door incubatie van bloed met verschillende concentraties van waterstofperoxide $\left(\mathrm{H}_{2} \mathrm{O}_{2}\right)$, voorafgaand aan de incubatie met ATP en LPS-PHA. Resultaten tonen aan dat ATP zijn ontstekingsremmende effecten onverminderd behoudt in een situatie van hevige oxidatieve stress. ATP is bovendien ook in staat om hydroxylradicalen weg te vangen, wat wijst op een directe remming van oxidatieve stress door ATP zelf.

Het mechanisme dat verantwoordelijk is voor de ontstekingsremmende effecten van ATP in LPS-PHA-gestimuleerd bloed werd onderzocht in hoofdstuk 4. Het doel van deze studie was het identificeren van purinerge receptoren betrokken bij de ontstekingsremmende effecten van ATP door het gebruik van specifieke receptor agonisten en antagonisten. Resultaten laten zien dat de remming van TNF- $\alpha$ door ATP verloopt via activatie van de $\mathrm{P}_{2} \mathrm{Y}_{11}$ receptor en de stimulatie van IL-10 door ATP via activatie van de $\mathrm{P}_{2} \mathrm{Y}_{12}$ receptor. De gelijktijdige modulaties van ontstekingsbevorderende en ontstekingsremmende cytokines door ATP, wordt dus gereguleerd door verschillende purinerge receptoren.

In hoofdstuk 5 wordt het LPS-PHA-gestimuleerde volbloed model nader gekarakteriseerd door het afbraakprofiel van ATP in dit model verder te bestuderen. In LPS-PHA-gestimuleerd bloed wordt ATP langzaam afgebroken, waarschijnlijk door de verlaagde ecto-enzym concentraties in dit model. In dit hoofdstuk bespreken we ook het tijdsafhankelijke effect van ATP en de afbraakproducten van ATP op verschillende cytokines, geïnduceerd op verschillende tijdstippen na LPSPHA stimulatie. ATP remde de LPS-PHA-geïnduceerde TNF- $\alpha$, interferon-gamma $($ IFN- $\gamma$ ) en IL-1 $\beta$ productie, maar stimuleerde de productie van IL-8 en IL-10. Deze effecten van ATP waren snel (2,4 en 6 uur na LPS-PHA stimulatie) en bleven behouden tot 24 uur na stimulatie. Geen van de afbraakproducten van ATP had een vergelijkbaar werkingsprofiel als ATP, dat wil zeggen: deze diverse afbraakproducten vertoonden ofwel, geen, hetzelfde ofwel een tegengesteld effect t.o.v. ATP. Tenslotte laten we zien dat ATP de LPS-PHA-geïnduceerde activatie van de transcriptie factor nuclear factor kappaB $(\mathrm{NF} \kappa \mathrm{B})$ remt op een tijdstip van 2 uur na stimulatie hetgeen wijst op een vroeg remmend effect van ATP op NFkB.

In hoofdstuk 6 worden de effecten van ATP op bestralings-geïnduceerde schade na ex vivo bestraling van bloed van gezonde vrijwilligers nader bestudeerd. Ex vivo 
bestraling van bloed leidde tot cytokineproductie, DNA-schade en depletie van de lichaamseigen antioxidant glutathion in de rode bloedcellen. ATP remde de bestralings-geïnduceerde TNF- $\alpha$ productie en stimuleerde de bestralingsgeïnduceerde IL-10 productie. Bovendien beschermde ATP normale bloedcellen effectief tegen bestralings-geïnduceerde DNA-schade.

In hoofdstuk 7 vergelijken we de oxidatieve stress en ontstekingsstatus in bloed van patiënten met niet-kleincellige longkanker en gezonde controle personen, die met de patiëntengroep overeenkwamen in leeftijd, geslacht en rookgedrag. Bovendien is in bloed van beide groepen ook de ex vivo ontstekingsremmende effecten van ATP bepaald. Bloed van longkankerpatiënten vertoonde in vergelijking met de controle groep een ontregeld antioxidant-systeem, zoals blijkt uit de verlaagde waarden van de glutathion peroxidase activiteit en verhoogde waarden van de glutathion-S-transferase activiteit en van malondialdehyde, ook was in het bloed van de kankerpatiënten sprake van een verhoogde ontstekingsactiviteit, blijkend uit verhoogde waarden van TNF- $\alpha$ en verlaagde waarden van albumine. Bovendien had ATP ontstekingsremmende effecten in ex vivo gestimuleerd bloed van zowel kankerpatiënten en gezonde controles. Deze ontstekingsremmende effecten van ATP waren direct proportioneel met de graad van ontsteking, dus: hoe sterker de ontsteking was, des te sterker was ook het corrigerende effect van ATP.

Tenslotte worden in hoofdstuk 8 de voornaamste bevindingen van de studies die beschreven zijn in dit proefschrift bediscussieerd.

We concluderen dat de gegevens van dit proefschrift de waarde bevestigen van ATP als een natuurlijke stof, met sterke effecten op processen zoals ontsteking en oxidatieve stress. Veel van de in dit proefschrift gerapporteerde effecten van ATP zijn niet eerder beschreven, zoals de ontstekingsremmende effecten ATP in LPSPHA-gestimuleerd en bestraald bloed en het beschermende effect van ATP op bestralings-geïnduceerde DNA schade in bestraald bloed. Onze experimenten tonen aan dat ATP, door het gunstig beïnvloeden van de balans tussen ontstekingsremmende en ontstekingsbevorderende cytokines, een sterk ontstekingsremmend effect heeft via de activatie van verschillende purinerge receptoren, en dat deze effecten aanwezig blijven onder omstandigheden van oxidatieve stress. Bovendien vangt ATP hydroxylradicalen weg en vermindert de bestralingsschade aan bloedcellen, door bescherming tegen bestralingsgeïnduceerde ontsteking en DNA schade. 



\section{Dankwoord}

Mijn naam mag dan wel op de voorpagina van dit proefschrift staan, ik had dit echter nooit kunnen verwezenlijken zonder de steun van vele mensen op de lange weg naar dit eindresultaat. Daarom wil ik al deze mensen, en een aantal in het bijzonder, hier graag hartelijk bedanken.

Allereerst zou ik Prof. dr. Aalt Bast en Prof. dr. ir. Piet van den Brandt, mijn promotores, en Dr. ir. Pieter Dagnelie, mijn copromotor, willen bedanken voor de kans die ze me gegeven hebben om met dit onderzoeksproject te starten. Pieter, bedankt om mij de afgelopen 4 jaar op dit interessante maar soms hobbelige pad zo goed te hebben begeleid. Je stuwende invloed, je snelle en essentiële feedback en bovenal je passie voor het onderwerp maakten dit resultaat mogelijk! Aalt, bedankt voor je vertrouwen, je enthousiaste begeleiding en voor het aanrijken van sleutelideeën om tot nog betere resultaten te komen. Je aanhoudende 'grapkes' over mijn Vlaamse verkleinwoordjes maakte onze werkoverleggen bovendien heel erg aangenaam! Piet, bedankt voor de snelle verbeteringen van de manuscripten en voor het geven van je nuttige commentaar, voornamelijk in de afrondingsfase van het proefschrift.

Verder wil ik graag mijn collega's van de vakgroep Farmacologie en Toxicologie bedanken voor de fijne samenwerking en aangename werksfeer. Een aantal mensen wil ik speciaal bedanken: Agnes, bedankt dat je altijd voor me klaarstond zowel voor werkgerelateerd advies als voor privé-dingen...zelfs vanuit Amerika wist je me, met je opbeurende mailtjes en lieve kaartjes, een hart onder de riem te steken. Uwe 'huis-belg' is je dankbaar voor alle steun! Gertjan, mijn ex-kamergenoot (en trotse vader van Floris), bedankt voor je luisterend oor als ik het even moeilijk had. De korte bezoekjes van Floris aan onze kamer, tijdens de laatste maanden van het schrijven, deden mij al mijn zorgen vergeten! Guido, bedankt voor de nuttige tips en relevante vragen tijdens de werkbesprekingen. Marc, bij jou kon ik altijd terecht met mijn kleine en grote vraagjes. Bedankt dat je altijd bereid was om me te helpen, ook al was ik voor een deel AIO bij Epidemiologie (grapje hoor!). Marie-José, je hulp bij de analyses van mijn laatste studie hebben me heel wat stress en tijd bespaard. Bedankt voor je snelle en flexibele inzet! Verder wil ik alle AIO's bedanken voor de steun en gezelligheid op het lab: Liesbeth, Saskia, Erik, Jiska, Shufan en Hilde (mijn nieuwe gezellige kamergenoot!). De uitstapjes naar Themby's moeten we blijven volhouden...zeker nu Hilde en Jiska de weg ook kennen! Ook Els en Mariëlle (en Mia) wil ik graag bedanken voor hun administratieve hulp. Mijn ex-collega's Rachelle en Mariken mag ik uiteraard ook niet vergeten. Rachelle, bedankt voor de leuke babbels, de thee-pauzes en de shop-dates samen met Agnes. Mariken, bedankt voor je enthousiasme en behulpzaamheid...spring nog maar eens binnen als je in de buurt bent want het is altijd fijn jou nog eens te zien! 
Vervolgens een speciaal dankwoordje voor mijn paranimfen, Evi en Roger. Eerst en vooral bedankt dat jullie mijn paranimfen willen zijn, het voelt nu al een stuk rustiger aan omdat ik weet dat jullie op 12 april naast me zullen staan! Bedankt voor jullie steun, bezorgdheid en koffie-klets-pauzes in de afrondingsfase van mijn proefschrift! Evi, door jou te leren kennen had ik wat 'Belgische ondersteuning' tussen onze Nederlandse collega's, maar het voornaamste is dat ik er nu een vriendin bij heb! Bedankt nog voor het meten van mijn plaatjes, het aanleren van de Comet assay en het lenen van je 'super' laptop. Het samen meten van 'de NFкB assay', zal ik niet snel vergeten...welke buffer was het ook alweer...CBB toch!? Roger(ke), zo een behulpzame kerel als jij kom je niet vaak tegen! Ook al had ik een vraag waar je niet dadelijk een antwoord op had, even later stond je in de deuropening: 'kijk eens even in je mailbox'. Bovendien was ik mijn dipjes en stress momenten snel te boven door je zo typerende positivisme en humor. En nog een extra dankwoordje voor de vormgeving van de kaft...mercikes!

Uiteraard wil ik ook graag mijn collega's van de vakgroep Epidemiologie bedanken en in het bijzonder mijn collega's van de 'ATP groep': Martijn, bij jou kon ik altijd terecht voor een discussie over mijn, volgens jou, 'altijd zo interessante en leuke' data, want jij bent de 'immunologie specialist' binnen onze groep. Bedankt voor je betrokkenheid en leuke periodes tijdens de congressen! Sandra, het tegelijktijdig schrijven van een subsidieaanvraag tijdens een AlO periode kan zwaar zijn he...maar het is ons beiden mooi gelukt! Bedankt voor je woorden van steun toen en succes met schrijven de komende maanden! Shireen, fijn dat je mij altijd op de hoogte bracht van gemiste overleggen en nieuwe ontwikkelingen in de patiëntenstudie. Bedankt voor je bezorgdheid, voornamelijk tijdens de laatste drukke maanden! Ilja, we kennen elkaar nog niet zolang, maar uit onze zowel algemene babbels als werkoverleggen kan ik nu al afleiden dat we nog een leuke periode als collega's tegemoet gaan! Erik, bedankt voor je hulp bij de HPLC bepalingen! Nicole en Brigitte, onze toffe onderzoeksassistenten, bedankt voor jullie betrokkenheid! Ik kijk er al naar uit om met jullie allemaal verder samen te werken en om nog vele ATP-uitjes en etentjes mee te maken! Ook de ex-collega's van de ATP groep, Anouk, Arno en Maggy, zou ik willen bedanken voor de leuke momenten die we samen gehad hebben. Nathalie en Yvonne, de secretaresses van Epidemiologie, bedankt dat jullie mij, terwijl ik een werkplek aan de overkant had, toch altijd goed ontvangen en geholpen hebben!

Ook mensen van andere afdelingen hebben me op de een of andere manier gesteund: Harald, ook al ging het over het lenen van een LPS flesje, prikken van proefpersonen en bejaarden of advies over de layout van mijn figuren...jij stond altijd voor me klaar...bedankt! En je volgende muzikale optreden in België willen we zeker niet missen! Twan, bedankt voor je hulp bij de bestralingsexperimenten en succes 
nog met je eigen promotieonderzoek! Kim, bedankt voor de leuke babbels (laatste tijd voornamelijk op de gang vanwege te druk) en succes met schrijven. Gunter, bedankt om me zo goed te hebben opgevangen tijdens mijn eerste weken als AIO bij jou op het lab.

De leden van de beoordelingscommissie wil ik bedanken voor hun bereidbaarheid om mijn proefschrift te lezen.

En natuurlijk zorgen familie en vrienden voor de welgekomen afwisseling in drukke tijden. Els, Nathalie, Annelies, Yannic, Lieve, Ellen en Evi, mijn 'high-school'vriendinnen: de verjaardagsfeestjes en afspraakjes in het weekend moeten we nog jaren volhouden! Dames van het tennisteam: Evi, Sabine, Nathalie en Chris, bedankt voor de fijne tennispartijtjes...dit jaar gaan we er weer tegenaan tijdens de zomerinterclub he!

Mijn (toekomstige) schoonouders Thieu en Mien, mijn broer Bart en Marie-Ange: bedankt voor jullie gemeende interesse en steun! 'Bompa Tongeren', fijn dat je altijd zo geïnteresseerd bent in mijn bezigheden 'bij de Hollanders'. 'Bompa Neerepen', dit jaar vieren we je $95^{\text {ste }}$ verjaardag: je relativeringsvermogen heeft me veel bijgebracht.

Oma, 'bonne', een speciaal woordje voor jou, het is nu al bijna 1 jaar geleden dat je toch wel plots bent moeten gaan...wat jammer dat je er niet kan bijzijn, want dat had je zo graag gewild. Je voelbare steun dreef me de laatste maanden vastberaden vooruit. Ik weet dat je trots op me bent en mijn proefschrift draag ik dan ook op aan jou!

Mama en papa. Bedankt voor jullie steun in alles wat ik doe en jullie niet aflatende geloof in mij. Bedankt dat jullie altijd voor me klaarstaan!!

Liefste Stein, bedankt voor de rust, je steun en je liefde. Ik kijk al uit naar 'onze' grote dag in september!!

Bedankt allemaal!

Els 



\section{Curriculum vitae}

Els Swennen werd geboren op 27 april 1979 te Tongeren, België. Na het voltooien van het secundair onderwijs aan het Koninklijk Atheneum in Tongeren, begon ze in 1997 aan het Limburgs Universitair Centrum (tegenwoordig Universiteit Hasselt) te Diepenbeek de studie 'Scheikunde'. In 1999 vervolgde zij deze studie aan de Rijks Universiteit van Gent (RUG). Na het behalen van het diploma 'Licentiaat in de Scheikunde' in 2001, volgde zij als aanvullende studie 'Farmaceutische Biotechnologie' aan de RUG, waar zij in 2002 haar diploma behaalde. Tijdens haar studie rondde zij twee stages af aan de RUG. In haar eerste stage onderzocht ze de eigenschappen van agarose-gelatine netwerken voor toepassing bij wondbehandeling van de huid. In haar tweede stage deed ze onderzoek naar het gedrag van polymeer-DNA-complexen in de extracellulaire matrix van epitheelcellen voor toepassing als gentherapie ter behandeling van cystic fibrosis.

Vanaf november 2002 tot eind 2006 was zij werkzaam als assistent in opleiding bij de capaciteitsgroepen Epidemiologie en Farmacologie \& Toxicologie, onder begeleiding van Dr. ir. P.C. Dagnelie, Prof. dr. A. Bast en Prof. dr. ir. P.A. van den Brandt, alwaar het onderzoek beschreven in dit proefschrift werd uitgevoerd. Gelijktijdig participeerde zij in een gerandomiseerde klinische studie naar de effectiviteit van ATP bij patiënten met niet-klein-cellige longkanker tijdens en na radiotherapie. Bovendien schreef zij in 2006, in samenwerking met P.C. Dagnelie en A. Bast, een onderzoeksvoorstel naar de effecten van ATP op GSH modulatie in kankercellen, dat door de 'Stichting Nationaal Fonds tegen Kanker' werd gehonoreerd. Sinds begin 2007 is zij werkzaam als postdoc bij de afdelingen Farmacologie \& Toxicologie en Epidemiologie, Universiteit Maastricht. 



\section{List of publications}

\section{Full papers}

Swennen E.L.R., Bast A. and Dagnelie P. C. Immunoregulatory effects of adenosine 5 '-triphosphate on cytokine release from stimulated whole blood. European Journal of Immunology 2005; 35: 852-858.

Swennen E.L.R., Dagnelie P. C. and Bast A. ATP inhibits hydroxyl radical formation and the inflammatory response of stimulated whole blood even under circumstances of severe oxidative stress. Free Radical Research 2006; 40: 53-58.

Swennen E.L.R., Bast A. and Dagnelie P. C. Purinergic receptors involved in the immunomodulatory effects of ATP in human blood. Biochemical and Biophysical Research Communications 2006; 348: 1194-1199.

Bours M.J.L., Swennen E.L.R., Di Virgilio F., Cronstein B.N. and Dagnelie P.C. Adenosine 5'-triphosphate and adenosine as endogenous signaling molecules in immunity and inflammation. Pharmacology \& Therapeutics 2006; 112: 358-404.

Swennen E.L.R., Coolen J.C.M., Arts I.C.W., Bast A. and Dagnelie P.C. Timedependent effects of ATP and its degradation products on inflammatory markers in human blood ex vivo. Submitted, 2007.

Swennen E.L.R., Dagnelie P.C., van den Beucken T. and Bast A. Radioprotective effects of ATP in human blood ex vivo. Submitted, 2007.

Swennen E.L.R., van den Broek S.A.W., Boots A.W., Arts I.C.W., van den Brandt P.A., Bast A. and Dagnelie P.C. Inflammatory and oxidative stress status in NSCLC patients and the ex vivo immunomodulatory effects of ATP in stimulated blood: a pilot study. Submitted, 2007.

Boots A.W., Wilms L.C., Swennen E.L.R., Kleinjans J.C.S., Bast A. and Haenen G.R.M.M. The anti-inflammatory activity of quercetin. Submitted, 2006.

Boots A.W., Drent M., Swennen E.L.R., Moonen H.J.J., Bast A. and Haenen G.R.M.M. Anti-oxidant status associated with inflammation in sarcoidosis: a potential role for antioxidants. Submitted, 2006.

Boots A.W., Drent M., Swennen E.L.R., Moonen H.J.J., Bast A. and Haenen G.R.M.M. Antioxidant and inflammatory status in patients suffering from idiopathic pulmonary fibrosis: a possible role for quercetin. In preparation, 2007. 


\section{Abstracts}

Swennen E.L.R., Bours M.J.L. Agteresch H.J., Kenis G., Maes M., Dagnelie P.C. Cytokine levels do not explain the favorable clinical effects of ATP infusion on the nutritional status and quality of life of patients with advanced cancer. $4^{\text {th }}$ International Symposium of Nucleotides and Nucleosides, Purines 2004, Chapel Hill, North Carolina, USA, June 2004.

Swennen E.L.R., Bast A., Dagnelie P.C. ATP inhibits the inflammatory response in stimulated blood, even under circumstances of severe oxidative stress. $8^{\text {th }}$ International Symposium on Adenosine and Adenine Nucleotides, Ferrara, Italy, May 2006. Purinergic Signalling 2006; 2: 121.

Coolen J.C.M., Swennen E.L.R., Bast A., Dagnelie P.C. ATP metabolism in human blood. $8^{\text {th }}$ International Symposium on Adenosine and Adenine Nucleotides, Ferrara, Italy, May 2006. Purinergic signalling 2006; 2; 121-2.

Swennen E.L.R., Arts I.C.W., Bast A., Dagnelie P.C. ATP inhibits the inflammatory response in stimulated blood, even under circumstances of severe oxidative stress. 'Oxidative stress and inflammation' GREMI meeting, Paris, France, January 2007.

\section{Patent applications}

Dagnelie P.C., Swennen E.L.R., Bast A., Skrabanja A., Beijer S., Bours M. Use of ATP for the manufacture of a medicament for the prevention and treatment of oxidative stress and related conditions. PCT/EP2005/005652, May 23, 2005.

Dagnelie P.C., Swennen E.L.R., Bast A. Identification of purinergic receptors involved in the immunomodulatory effects of ATP in human blood. Provisional application 60/784/219, March 20, 2006. 